


\title{
The Geological Society of Australia
}

\author{
Extended \\ ABSTRACTS
}

\section{Number 91}

The Geological Society of Australia

Victoria Division

www.vic.gsa.org.au

\section{SELWYN SYMPOSIUM 2008}

\section{Neoproterozoic extreme climates and the origin of early metazoan life}

Thursday 25 September 2008

Fritz-Loewe Theatre, The University of Melbourne

Editors: Stephen J. Gallagher \& Malcolm W. Wallace

The School of Earth Sciences,

The University of Melbourne,

Victoria 3010,

Australia. 
Melbourne University

$25^{\text {th }}$ September 2008

Geological Society of Australia Extended Abstracts Number 91

Geological Society of Australia Victoria Division Selwyn Symposium 2008

Editors: Assoc. Prof. Stephen J. Gallagher and Assoc. Prof. Malcolm W. Wallace

ISSN $0729011 \mathrm{X}$

(C) Geological Society of Australia Incorporated, 2008

Preferred Citation:

Gallagher S.J. \& Wallace, M.W. 2008. Neoproterozoic extreme climates and the origin of early metazoan life, Selwyn Symposium of the GSA Victoria Division, September 2008, Geological Society of Australia Extended Abstracts No. 91, 72 pp.

Example Citation for papers in this volume:

Giddings, J. 2008. Facies-dependant $\delta^{13} \mathrm{C}$ variation from an interglacial platform margin, South Australia: Evidence for ocean stagnation during the Cryogenian? In: Gallagher S.J. \& Wallace M.W. (eds). Neoproterozoic extreme climates and the origin of early metazoan life, Selwyn Symposium of the GSA Victoria Division, September 2008, Geological Society of Australia Extended Abstracts No. 91, p. 35-44.

Copies of this publication may be obtained from:

The Business Manager

Geological Society of Australia Incorporated

Suite 706 Thakrai House, 301 George Street

Sydney NSW 2000 Australia 


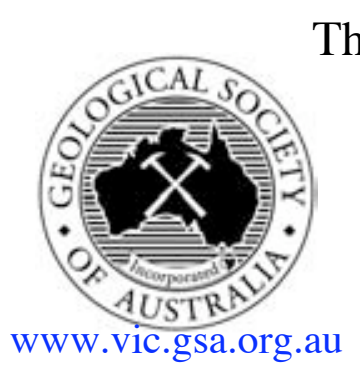

The Geological Society of Australia Victoria Division

presents the

SELWYN SYMPOSIUM 2008

Thursday 25 September 2008

Fritz-Loewe Theatre, Earth Sciences

University of Melbourne

Alfred Richard Cecil Selwyn (1824-1902)

The Selwyn Memorial Lecture was introduced in 1984 to commemorate the work of A.R.C. Selwyn, the first Government Geologist of Victoria. This year represents the $155^{\text {th }}$ anniversary of the Government Geological Survey in Victoria. In recent years the Lecture has followed a symposium, involving invited speakers on a significant theme for Australian Geology, to celebrate Selwyn's work.

Alfred Selwyn was born in Somerset, England in 1824, and had a strong Church of England upbringing. He was educated in Switzerland where he developed an enthusiasm for geology. At the age of 21 he joined the Geological Survey of Great Britain under the direction of A. C. Ramsay in North Wales and was soon entrusted with independent mapping of large areas with key Silurian rocks.

The discovery of Gold in Victoria in 1851 led Governor La Trobe to ask the Colonial Office in London for "a gentleman possessed of the requisite qualifications and acquaintance with geological science and phenomenon." Selwyn was awarded the post at an annual salary of 500 pounds and arrived in early December 1852. Almost immediately he commenced a series of wide ranging reconnaissance trips during which he studied the geology of Victoria with excursions into Tasmania and South Australia. Among many of the early records, the Geological Survey holds an original watercolour version of his 1856 map of the Yarra Basin and Western Port.

Selwyn set up the Geological Survey proper in 1856 and gathered around him and trained a team of geologists including: Alpin, Ulrich, Wilkinson, Daintree, Taylor, Brown and Etheridge. They subsequently occupied senior positions in all mainland State Geological Surveys and became renowned in the early annals of Australian geology. Selwyn and his team established the 6-mile x 9mile Victorian quarter sheet mapping programme of which 65 were produced.

Selwyn was quiet and reserved man of indomitable disposition who carried out his plans despite all hindrances and achieved an amount of work that few could emulate. However, conflict arose from the overlapping activities of mining surveyors. The Survey often held views on scientific standards and policies opposed to those of the colonial officials and legistrators, in particular that of R. Brough Smyth, Secretary of Mines.

Consequently, Selwyn resigned in 1869 and the Survey was disbanded for a year. Selwyn left Australia and was appointed the Director of the Geological Survey of Canada on retirement of Sir William Logan. He worked with distinction from 1869 until his retirement in 1894.

Selwyn was awarded the prestigious Murchison Medal of the Geological Society of London in 1876. Other honours followed in Great Britain. The only recognition from Australia was his Clark Gold Medal from the Royal Society of New South Wales in 1884 . He is commemorated in Victoria by an annual Geological Society of Australia Victoria Division lecture, symposium and medal. 


\section{Neoproterozoic extreme climates and the origin of early metazoan life}

Selwyn Symposium Summary: Climatically, the Neoproterozoic ( $750-550$ million years ago) is one the most extraordinary periods of Earth history. During this time, the Earth was alternately subjected to the most severe glacial conditions ("snowball earth events") the planet has ever witnessed (with ice present in equatorial latitudes), and then to similarly widespread tropical greenhouse conditions. These extreme climates, together with the sudden and widespread appearance of soft-bodied metazoan organisms during the Ediacaran ( 600-544 million years ago) make the Neoproterozoic one of the most important and enigmatic episodes in Earth history. This symposium brings together leading researchers to examine the causes and effects of these extreme climatic events and the evolution of early metazoan life.

Assoc. Prof. Stephen Gallagher and Assoc. Prof. Malcolm Wallace, Selwyn Symposium organising committee

\section{The Geological Society of Australia, Victoria Division}

The Geological Society of Australia (GSA) was established in 1952 as a learned non-profit organisation. The Society's objectives have been expanded to promote, advance and support the Earth Sciences within the scientific and wider communities.

The GSA Victoria Division holds scientific meetings on the last Thursday of each month at the University of Melbourne University starting at 6.15 preceded by light refreshments from $5.30 \mathrm{pm}$. It publishes geological books (such as the Geology of Victoria), and acknowledges geological leadership and accomplishment through various awards through the Selwyn Award and Symposia.

Anyone interested is also welcome to attend the monthly committee meetings of the GSAV, which usually begin at $4 \mathrm{pm}$ in a venue near the general meeting venue. For further information check our website: www.vic.gsa.org.au.

GSAV Committee 2008

OFFICE BEARERS

Chair:

Vice-chair:

David Cantrill

Secretary:

Treasurer:

\section{SUBCOMMITTEE}

Awards:

Bicentennial Gold:

Education:

Heritage:

Membership:

Newsletter:

Program:

Publications:

Promotions

Webmaster:

Geology of Victoria:
Vacant

Adele Seymon

Stephen Gallagher

Vacant

Ingrid Campbell

Gerhard Krummei

Noel Schleiger

Susan White

Vacant

Alison Fairmaid/Kyle Rebryna

Vacant

Vacant

Vacant

Lindsay Thomas

\section{COMMITTEE}

Susan White

Alison Fairmaid

Chung Leong Li

Lindsay Thomas

David Moore

Kyle Rebryna

Noel Schleiger 


\section{Neoproterozoic extreme climates and the origin of early metazoan life $25^{\text {th }}$ September 2008 \\ PROGRAM \& PAGE INDEX}

\begin{tabular}{|c|c|c|c|}
\hline 8.00-9.00 & \multicolumn{3}{|l|}{ Registration } \\
\hline 9.00-9.15 & \multicolumn{3}{|c|}{ Introduction: Assoc Prof Stephen Gallagher \& Assoc Prof Malcolm Wallace } \\
\hline $9.15-9.30$ & \multicolumn{3}{|c|}{ Opening address: Prof Peter Rathjen, DVC Research, University of Melbourne } \\
\hline $9.20-10.00$ & $\begin{array}{c}\text { Plenary Address: Prof Malcolm Walter } \\
\text { University of NSW }\end{array}$ & 1. The emerging history of the eucaryotes prior to the Ediacaran & Page: 1 \\
\hline $10.00-10.30$ & $\begin{array}{l}\text { Patricia Vickers Rich, } \\
\text { Monash University } \\
\end{array}$ & 2. Salt, Oxygen, Gargantuan Mountains and the Rise of the Animalia & Page: 3 \\
\hline \multirow[t]{2}{*}{ 10.30-11.00 } & \multicolumn{3}{|l|}{ Morning Tea } \\
\hline & \multicolumn{3}{|c|}{ Chairs of session: Paul Hoffman \& Wolfgang Preiss } \\
\hline $11.00-11.30$ & $\begin{array}{l}\text { Kath Grey, } \\
\text { Geological Survey of WA } \\
\end{array}$ & $\begin{array}{l}\text { 3. Biostratigraphic correlation of Neoproterozoic glacial successions } \\
\text { in Australia }\end{array}$ & Page: 5 \\
\hline $11.30-12.00$ & $\begin{array}{l}\text { Jim Gehling, } \\
\text { South Australian Museum }\end{array}$ & $\begin{array}{l}\text { 4. Ediacarans on the Edge: Environmental Controls on Diversity of the } \\
\text { Ediacara biota }\end{array}$ & Page:13 \\
\hline $12.00-12.30$ & $\begin{array}{c}\text { Malcolm Wallace \& Estee Woon, } \\
\text { Melbourne University }\end{array}$ & 5. Giant Cryogenian reefs as a window into pre-Ediacaran life & Page: 17 \\
\hline \multirow[t]{2}{*}{ 12.30-1.30 } & \multicolumn{3}{|l|}{ Lunch } \\
\hline & \multicolumn{3}{|c|}{ Chairs of session: Rick Squire \& Malcolm Walter } \\
\hline $1.30-2.00$ & $\begin{array}{l}\text { Paul F. Hoffman } \\
\text { Harvard University } \\
\end{array}$ & $\begin{array}{l}\text { 6. Evidence for large glacioeustatic changes associated with the 635-Ma } \\
\text { Glaciation in Namibia }\end{array}$ & Page: 23 \\
\hline $2.00-2.30$ & Wolfgang Preiss, PIRSA & $\begin{array}{l}\text { 7. The tectonic and palaeogeographic setting of Australia's } \\
\text { Neoproterozoic rock record }\end{array}$ & Page: 29 \\
\hline $2.30-3.00$ & $\begin{array}{l}\text { Jon Giddings, } \\
\text { Melbourne University }\end{array}$ & 8. Evidence for ocean stagnation during the Cryogenian & Page: 35 \\
\hline $3.00-3.30$ & $\begin{array}{l}\text { Clive Calver, } \\
\text { Geological Survey of Tasmania }\end{array}$ & 9. Tasmanian Neoproterozoic glacial deposits & Page: 45 \\
\hline \multirow[t]{2}{*}{ 3.30-3.55 } & \multicolumn{3}{|l|}{ Afternoon tea } \\
\hline & \multicolumn{3}{|l|}{ Chairs of session: Clive Calver \& Kath Grey } \\
\hline $3.55-4.25$ & $\begin{array}{l}\text { Galen Halverson, } \\
\text { University of Adelaide }\end{array}$ & 10. A Neoproterozoic Oxygenation Event & Page: 49 \\
\hline $4.25-4.55$ & \begin{tabular}{|c|} 
Rick Squire, \\
Monash University
\end{tabular} & 11. Supermountains, Hendrix and the $\mathrm{O} 2$-rich elixir for animal life & Page: 55 \\
\hline $4.55-5.20$ & $\begin{array}{l}\text { Mark Fanning } \\
\text { Australian National University }\end{array}$ & $\begin{array}{l}\text { 12. Age constraints for the Sturtian Glaciation; data from the Adelaide } \\
\text { Geosyncline, South Australia and Pocatello Formation, Idaho, USA }\end{array}$ & Page: 57 \\
\hline $5.20-5.30$ & \multicolumn{3}{|c|}{ Discussion \& conclusions Chaired by Patricia Vickers-Rich and Paul Hoffman } \\
\hline $5.30-6.30$ & \multicolumn{3}{|l|}{ Drinks \& refreshments } \\
\hline $6.30-6.45$ & \multicolumn{3}{|c|}{$\begin{array}{l}\text { 13. Selwyn Medal presentation to Associate Professor Malcolm Wallace @ The Copland Theatre } \\
\text { for nominations see Page } 63\end{array}$} \\
\hline 6.45-8.00 & $\begin{array}{l}\text { 14. GSAVIC SELWYN LECTURE } \\
\text { Prof Paul Hoffman } \\
\text { Harvard University }\end{array}$ & $\begin{array}{l}\text { Historical geology, the Pleistocene glacial controversy, and the rise } \\
\text { of modern Earth science see Page } \mathbf{6 9}\end{array}$ & \\
\hline $8.15-$ & Selwyn Dinner & University House the University of Melbourne & \\
\hline
\end{tabular}




\section{NOTES (+ location of Copland Theatre)}

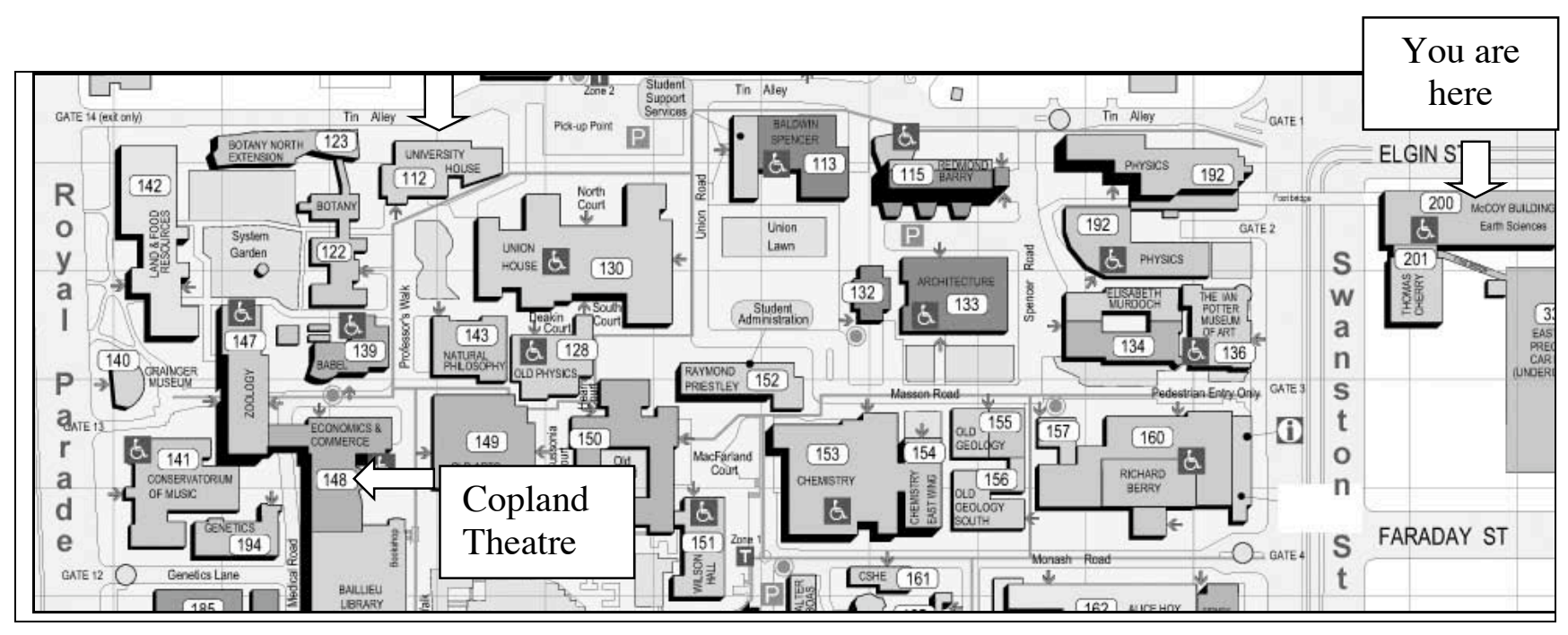




\section{The emerging history of eucaryotes prior to the Ediacaran (plenary address)}

Malcolm Walter

Australian Centre for

Astrobiology, University of

NSW, Sydney 2065

malcolm.walter@unsw.edu.au

\section{Biography:}

Malcolm Walter is Professor of Astrobiology and Director of the Australian Centre for Astrobiology at the University of NSW. He has worked for 45 years on the geological evidence of early life on Earth, and more recently on the search for life on Mars. He has also worked as an oil exploration consultant and a consultant to museums. In 2004 he was elected Fellow of the Australian Academy of Science. He has been awarded a Eureka Prize for his interdisciplinary research

The study of the early geological history of eucaryotes has changed substantially over the last 50 years. The time distribution of possible fossil eukaryotes was at first unconstrained and examples were reported from as far back in time as the Archaean. Over time these early reports were all discredited because of incorrect dating, reinterpreted biological affinities or revised abiological interpretations. So the accepted early record of eucaryotes contracted back to the Neoproterozoic, or even to the Ediacaran. Then, over the last two decades, concerted searches using modern techniques have pushed the record out again, though still not always convincingly. We are now seeing hints once again of eucaryotes as old as Archaean, even early Archaean.

Even if we consider only the metazoans the story is much the same. Leaving aside various eccentric interpretations of some Ediacaran fossils it is well established that by that time there was a diverse fauna of soft-bodied and skeletonised metazoans. On this basis it was predicted that there must be a metazoan "pre-history" waiting to be revealed (Glaessner, 1985). But it has not been revealed. The interpretations of some early Neoproterozoic calcareous microstructures (some of the "catagraph" of Soviet biostratigraphers) as faecal pellets never found favour, and the marked decline in stromatolite diversity and abundance in the early Neoproterozoic documented by Awramik (1971) and Walter \& Heys (1985) and attributed to the rise of grazing and burrowing metazoans was re-interpreted as due to the changing alkalinity of the oceans or to ecospace competition from macroscopic algae. This issue remains unresolved.

It is sometimes contended that the earliest history of the metazoans is unknown because palaeobiologists have not looked hard enough. Nothing could be further from the truth. Whole generations of palaeobiologists have scoured the many available well-preserved rock successions of pre-Ediacaran age hoping to make the big discovery. The literature is replete with reports of what are now considered to be dubiofossils and pseudofossils, but no convincing examples of metazoan fossils have ever been found. The obvious conclusion is probably the correct one: there were no macroscopic metazoans prior to the Ediacaran (with the possible exception of the "Twitya discs" of immediately pre-Ediacaran age in Canada; Narbonne, 2005). Glaessner's idea that there is a metazoan pre-history yet to be revealed is appealing, and perhaps inevitable, but it remains hidden.

Meanwhile, substantial progress has been made in uncovering the early history of the algae (Knoll et al., 2006). The history of the red algae has been extended to at least $1.2 \mathrm{Ga}$, and this is used to suggest a Mesoproterozoic/Neoproterozoic radiation of protists in general (Butterfield, 2000). Charles Walcott's discovery of structured carbonaceous impressions in the 1.45 Ga Belt Supergroup of Montana included a population of macroscopic coiled forms later described as Grypania spiralis by Walter et al. (1976) and tentatively regarded as algal eucaryotes. Han and Runnegar (1992) reported similar but smaller forms from 2.1 Ga iron formation from Michigan. Enigmatic "strings of beads" (Horodyskia) fossils that occur in possibly1.07-1.46 Ga siltstone and sandstone in Australia and North America have been tentatively interpreted as impressions of macroscopic algae, though other interpretations are possible (Grey et al., submitted). 
Among the microscopic fossils discovered the best preserved and most convincing as eucaryotes are the acritarchs of the 1.49 Ga Roper Group of Australia (Javaux et al., 2001). One taxon present, Tappania, has been interpreted as a fungus (Butterfield, 2005). The $\sim 2 \mathrm{Ga}$ Gunflint microbiota of Canada has long been known to include enigmatic elements for which a eucaryote affinity is sometimes suggested (particularly for Eosphaera).

Two intriguing discoveries push the record back into the Archaean. The first is of sterane biomarkers in the 2.7-2.8 Ga Fortescue Group of Western Australia (Brocks et al., 1999). Steranes are the geological products of sterols produced in oxygen-requiring biosynthetic pathways in eucaryotes. Despite some lingering doubts about the possibility that these particular biomarkers could be contaminants from later times, and that some bacteria produce similar but distinctive compounds, the weight of evidence is that the Fortescue steranes are indigenous and indicate the operation of one aspect of eucaryotic biosynthetic pathways at 2.7-2-8 Ga. Somewhat younger steranes found in fluid inclusions support this interpretation. Finally, and most tentatively, relatively large and complex microfossils discovered in cherts $3 \mathrm{Ga}$ and older in Western Australia and South Africa may hint at a eucaryote affinity (Sugitani et al., 2007).

Viewed at this scale, the record of eucaryotes is one of very slow but continuous evolution beginning sometime in the Archaean. The record is not yet well enough known for us to recognise any dramatic evolutionary events that might have occurred. The "sudden" appearance of macroscopic metazoans early in the Ediacaran may be the one exception.

\section{References}

Awramik, S. M. (1971). Precambrian columnar stromatolite diversity: reflection of metazoan appearance. Science 1974, 825-827.

Brocks J. J., Logan G. A., Buick R., Summons R. E. (1999). Archean molecular fossils and the early rise of eukaryotes. Science 285, 1033-1036.

Butterfield, N. J. (2000). Bangiomorpha pubescens n. gen., n. sp.: implications for the evolution of sex, multicellularity, and the Mesoproterozoic/Neoproterozoic radiation of eukaryotes. Paleobiology, 26, 386-404.

Butterfield, N. J. (2005). Probable Proterozoic fungi. Paleobiology, 31, 165-182.

Glaessner, M._(1985) The Dawn of Animal Life : A Biohistorical Study. Cambridge University Press.

Grey, K., Yochelson, E. L, Fedonkin, M.A., Martin, D. McB. (submitted) Horodyskia williamsii new species, a Mesoproterozoic megafossil from Western Australia. Alcheringa

Han, T.M., Runnegar, B. 1992. Megascopic eukaryotic algae from the 2.1 billion-year-old Negaunee Iron-Formation, Michigan. Science 257, 232-235.

Javaux, E., A.H. Knoll, M.R. Walter (2001). Ecological and morphological complexity in early eukaryotic ecosystems. Nature 412, 66-69.

Knoll, A. H., Javaux, E. J., Hewitt, D., Cohen, P. (2006). Eukaryotic organisms in Proterozoic oceans. Phil. Trans. R. Soc $B, \mathbf{3 6 1}, 1023-1038$.

Sugitani, K. ', Grey, K., Allwood, A., Nagaoka, T.,Mimura, K.,, Minami, M., Marshall, C. P., Van Kranendonk, M. J., Walter, M. R. (2007). Diverse microstructures from Archaean chert from the Mount Goldsworthy - Mount Grant area, Pilbara Craton, Western Australia: Microfossils, dubiofossils, or pseudofossils? Precambrian Research, 158 , 228-262.

Narbonne, G. M. (2005). The Ediacara Biota: Neoproterozoic Origin of Animals and Their Ecosystems. Annual Review of Earth and Planetary Sciences 33, 421-442.

Walter, M. R., Heys, G. R., (1985) - Links between the rise of the Metazoa and the decline of stromatolities. Precambrian Research, 29, 149-174.

Walter, M. R., Oehler, J. H. , Oehler, D. Z., 1976 - Megascopic algae 1300 million years old from the Belt Supergroup, Montana: a reinterpretation of Walcott's Helminthoidichnites. Journal of Paleontology, 50, 872-881. 


\section{Salt, Oxygen, Gargantuan Mountains and the Rise of Animals}

Patricia Vickers-Rich

School of Geosciences,

Monash University,

Melbourne, VIC 3800

Pat.Rich@sci.monash.edu.au

\section{Biography:}

Professor Patricia Vickers-Rich is Director of the Monash Science Centre, Monash University and a world-renowned palaeontologist and geologist. Vickers-Rich researches the origin and evolution of Australasian vertebrates and their environments over the past 400 million years. She has special interest in Australian avian fossil non-passerines. Patricia Vickers-Rich and Dr Tom Rich won the 2007 Selwyn Award.

The time from around 800 to 500 million years was perhaps rather chaotic at times - it was often changing. Temperatures rose and fell, ice cover waxed and waned (Hoffmann et al., 1998) oxygen levels increased (Knoll, 1996) perhaps sometimes rather dramatically and ocean chemistry and dynamics also changed. It was as some ecologists say, a very "weedy' period of time - and definitely a time of change - both physically and biologically. Such dynamism of the physical environment was most certainly linked to the rise of animals, amongst other things. Sorting out the chain of events and their timing is fascinating.

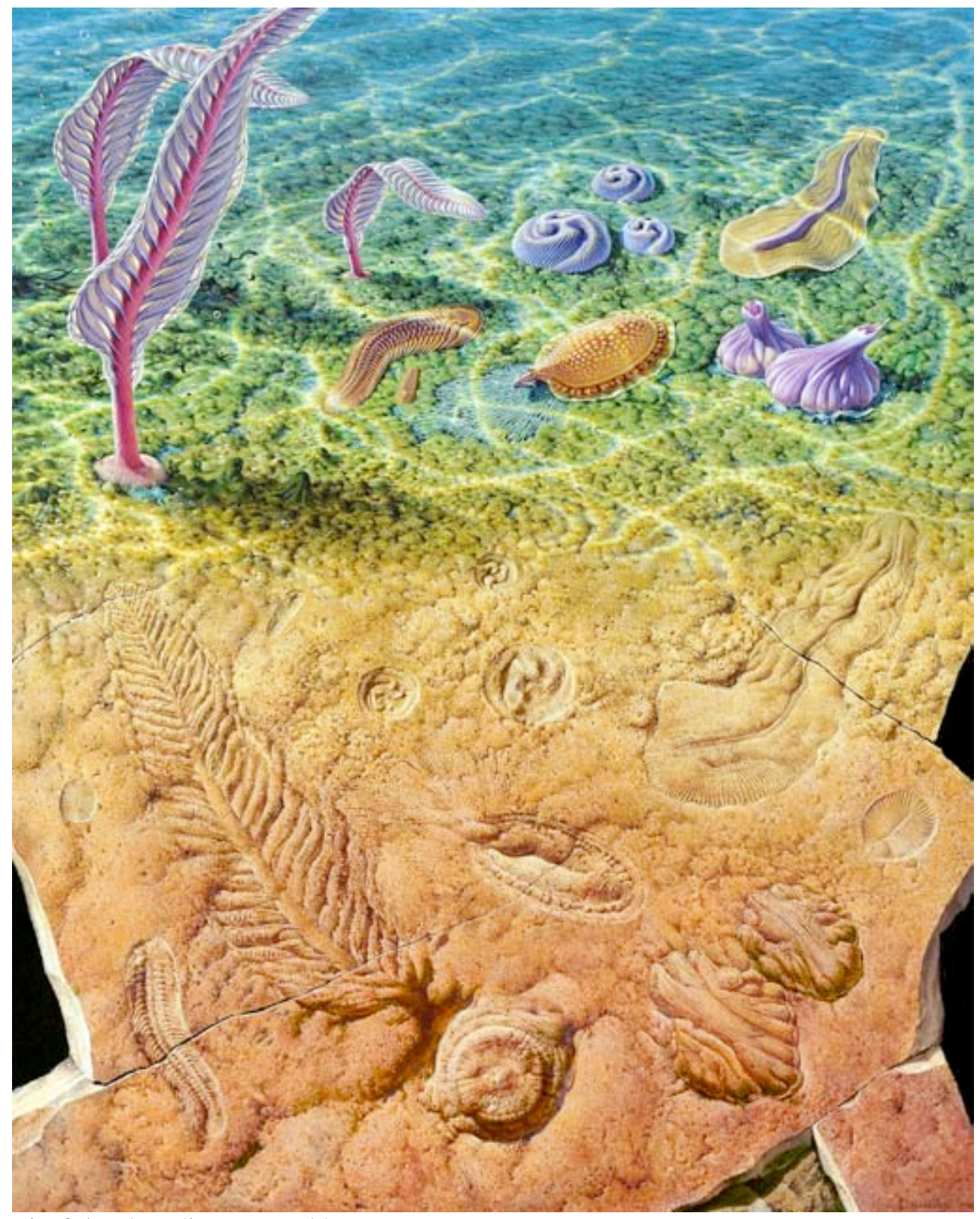

Fig. 2.1. The Ediacaran world. 
During this period gigantic saline deposits were formed, but the precise dating of formation is still not at hand - and questions as to how this affected the global oceans are yet to be answered. If, as some have suggested Knauth (2005) and Vickers-Rich (2007) this could have "sweetened" the seas by lowering salinity, it could have been one of the triggers that prompted metazoans which existed in less salty outposts that also had higher oxygen content to rapidly move into the "global playgrounds" that had been denied them (Figure 2.1). The rise of oxygen levels in global oceans and the chemical input of the truly monstrous Transgondwanan Mountain Range towards the end of this time (Squire et al., 2006) certainly had their effects, the latter most certainly having something to do with the laying down of hard skeletons and shells as Calcium and Phosphorous levels rose. If only Dr Who and his famous phone box could take us there to make precision observations!

\section{References}

Hoffmann, P. F et al., 1998. A Neoproterozoic Snowball Earth, Science, 281: 1342-1346.

Knauth, L. P., 2005. Temperature and salinity history of the Precambrian ocean: implication for the course of microbial evolution. In: N. Noffke, ed., Geobiology: Objectives, Concepts, Perspectives, Elsevier: 53-69.

Knoll, A. H., 1996. Breathing room for early animals. Nature, 382: 111-112.

Squire, R., et al., 2006. Did the Transgondwanan Supermountains trigger the explosive radiation of animals on Earth? Earth and Planetary Science Letters, 250.

Vickers-Rich, P., 2007. Saline giants, cold cradles and global playgrounds of Neoproterozoic Earth: the origin of the Animalia. In: P. Vickers-Rich \& P. Komarower, Eds. The Rise and Fall of the Ediacaran Biota. Geological Society of London special Publication, 286: 447-448. 


\section{Biostratigraphic correlation of Neoproterozoic glacial successions in Australia}

Kathleen Grey

Geological Survey of Western Australia

Department of Industry and Resources, 100 Plain Street East Perth WA 6004

kath.grey@doir.wa.gov.au
Biography:

Dr Kath Grey is Chief Palaeontologist at the Geological Survey of Western Australia, where she provides biostratigraphic and palaeoenvironmental data using stromatolites and acritarchs from the Archaean and Proterozoic for incorporation in GSWA maps and publications.

Australia-wide Neoproterozoic correlation and subdivision received a boost when the Ediacaran System and Period was ratified by the definition of a Global Stratotype and Section Point (GSSP) in the Flinders Ranges of South Australia. A revival of interest in hydrocarbon and mineral exploration in the extensive successions found in the Centralian Superbasin (the Officer, Amadeus, and Georgina Basins) and the correlative Adelaide Rift Complex has encouraged attempts to refine stratigraphy and correlation. Although geochronological constraints remain elusive, other methods have proved effective in improving subdivision of the Neoproterozoic and in advancing global correlation. These include lithostratigraphy, carbon and strontium isotope chemostratigraphy, palynology, and stromatolite biostratigraphy. Application of these methods produces internally consistent correlations.

To date, no unequivocal Tonian-aged successions (1000-850 Ma) have been identified in Australia. Part of the Callanna Group in the Adelaide Rift Complex may be Tonian, and the Townsend Quartzite, Pindyan Sandstone, Lefroy and Alinya Formations in the Officer Basin, the Kulail Sandstone, Dean and Heavitree Quartzites in the Amadeus Basin and lateral equivalents in the Georgina Basin could be Tonian if there is a stratigraphic break between these units and the Bitter Springs Formation and its lateral equivalents. Other possible Tonian successions include the Badgeradda, Cardup and Moora Groups around the Yilgarn Craton margins, the Lamil and Throssell Range Groups along the northeastern Pilbara margins, and the Rocky Cape Group in Tasmania.

By contrast, Australia has extensive Cryogenian and Ediacaran successions that can be readily correlated (Fig. 3.1). Pending decisions of the International Subcommission on Neoproterozoic (Cryogenian and Ediacaran) Stratigraphy, Cryogenian is here taken as extending from the chronometrically defined base at $850 \mathrm{Ma}$, through the currently chronometrically defined top at 650 $\mathrm{Ma}$, to include the overlying interval up to the chronostratigraphically defined base of the Ediacaran System and Period at the base of the Nuccaleena Formation in the Flinders Ranges of South Australia.

Cryogenian-age rocks, including the Sturtian and Elatina glaciations (for discussion of the terms Marinoan and Elatina glaciations see Williams et al., 2008) are present in the Officer, Amadeus, Georgina, Ngalia, Birrindudu, and Wolfe Basins, Adelaide Rift Complex, Tasmania and are widespread in the Kimberley and elsewhere across northern Australia. The Ediacaran succession is more restricted, but is present in the Officer, Amadeus, Georgina, Ngalia and Kimberley areas, and Adelaide Rift Complex, and possibly in Tasmania.

Precise U-Pb zircon and baddellyite dating for the Cryogenian and Ediacaran is limited but provides significant constraints (see Preiss, 2000). Sedimentation post-dates the Warakurna large igneous province and began after intrusion of the Stuart and Kulgera dyke swarms c.1080 Ma. 
a)

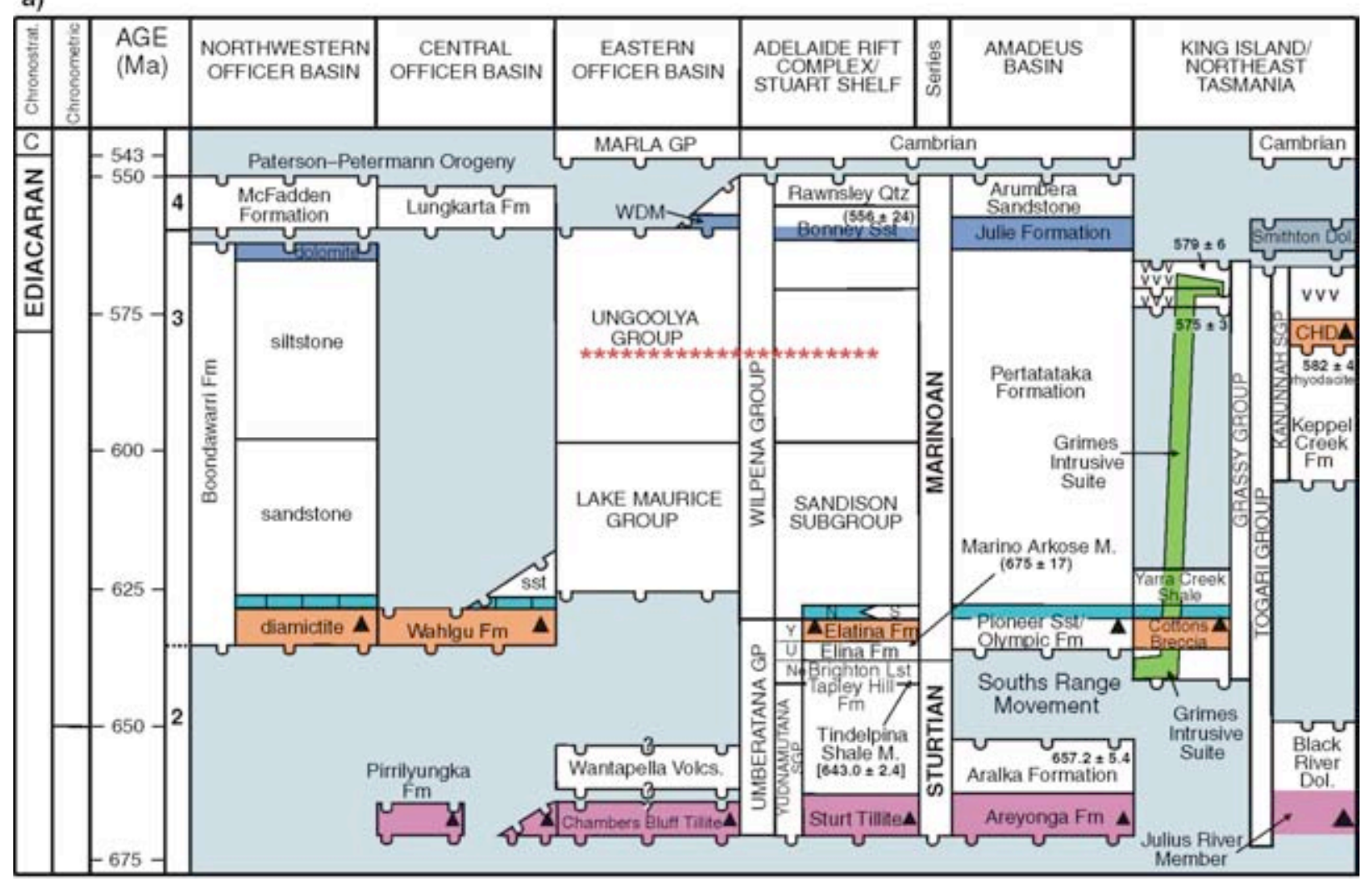

b)

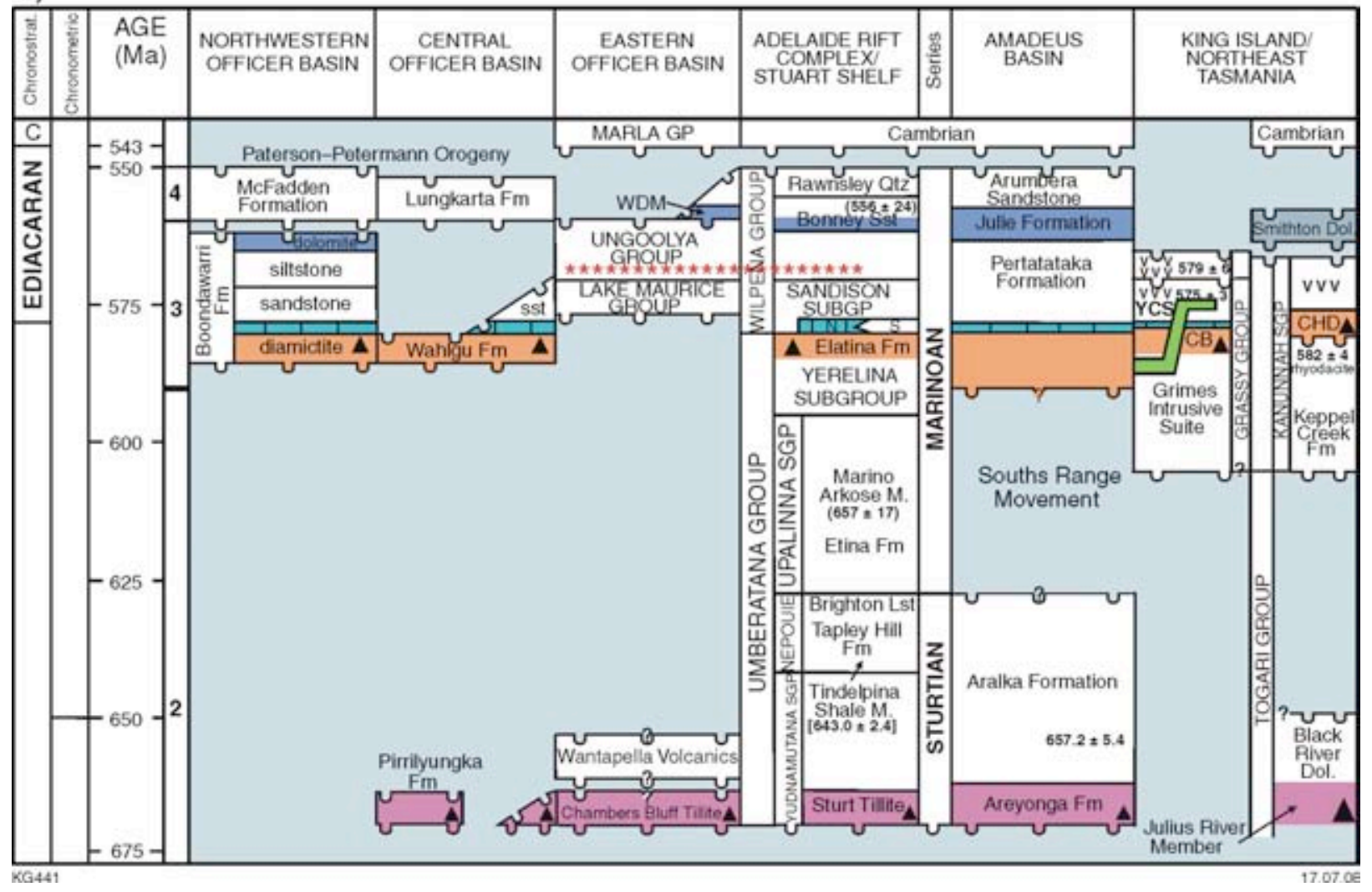

Fig. 3.1. Proposed correlation of selected stratigraphic units in Australia for the Officer and Amadeus Basins, Adelaide Rift Complex, Stuart Shelf, King Island and Tasmania. A) Assuming an age of c. 635 Ma for the Elatina glaciation and equivalents and B) assuming an age of $580 \mathrm{Ma}$ for the Elatina glaciation and equivalents. CB, Cottons Breccia; CHD, Croles Hill Diamictite; Ne, Nepouie Subgroup; N, Nuccaleena Formation; S, Seacliff Sandstone; U, Upalinna Subgroup; WDM, Wilari Dolomite Member; Y, Yerelina Subgroup; YCS, Yarra Creek Shale; Dol., Dolomite; Fm, Formation; GP, Group; SGP, Subgroup; M, Member; Lst, Limestone; Qtz, Quartzite; Volcs, Volcanics; sst, sandstone; VVV, volcanics; 
triangle, diamictite; asterisks, Acraman impact ejecta layer.

The younger Gairdner and Amata dyke swarms may slightly post-date the onset of deposition and provide zircon ${ }^{207} \mathrm{~Pb}-{ }^{206} \mathrm{~Pb}, \mathrm{U}-\mathrm{Pb}$ and baddellyite ages of 824-827 Ma. A Sm-Nd isochron of $802 \pm 35$ Ma on a Stuart Shelf dyke and concordant U-Pb SHRIMP zircon age of $802 \pm 10 \mathrm{Ma}$ on the Rook Tuff constrain the age of the Callanna Group. Rhyolite from the Boucaut Volcanics at the base of the Burra Group has a U-Pb SHRIMP zircon age of 777 \pm Ma. A detrital zircon U-Pb SHRIMP age of 725 \pm 11 Ma from the upper Kanpa Formation gives a maximum age for Sturtian glaciation in the western Officer Basin (Grey et al., 2005; Haines et al., 2008). Of particular significance is a U-Pb SHRIMP age of $658 \mathrm{Ma}$ on an ash bed within the Merinjina Tillite, a Sturt Tillite equivalent, which provides a definitive age for the Sturtian glaciation in Australia (Fanning and Link, 2006).

There is only limited dating above the Sturtian glaciation (Fig. 3.1). Re-Os ages of 657.2 $\pm 5.4 \mathrm{Ma}$ from the Aralka Formation in the Amadeus Basin, 643 \pm 2.4 Ma on the Tindelpina Shale Member of the Tapley Hill Formation in the Adelaide Rift Complex and 640.7 $\pm 4.7 \mathrm{Ma}$ from just above the glacial Julius River Member in northwest Tasmania are consistent with a c.658 Ma age for the Sturtian glaciation. Higher in the succession, a sedimentary zircon grain of $657 \pm 17 \mathrm{Ma}$ (similar to the Merinjina Tillite age) places a maximum age constraint on the Marino Arkose Member. Other dates in this part of the succession are based on $\mathrm{Rb}-\mathrm{Sr}$ isochrons from sedimentary rocks and are considered unreliable (Preiss, 2000).

The age of the younger Elatina glaciation remains uncertain, but because the Ediacaran boundary is placed at the base of the Nuccaleena Formation, the underlying diamictite and its lateral equivalents across Australia is here included in the Cryogenian. There is a widely accepted view that the Elatina Formation and overlying Nuccaleena Formation (the 'cap carbonate') correlates with the $635.5 \pm 1.2$ Ma Ghaub Formation in Namibia and a $635.2 \pm 0.6$ Ma ash bed within the cap dolostone above the Nantuo Tillite in China (Fig. 3.1). However, dating of glacial successions in King Island and Tasmania (Calver et al., 2004) suggests an alternative correlation (Fig. 9.3 Calver abstract this vol.).

On King Island, the Cottons Breccia, a diamictite containing compelling evidence for glaciation, and an overlying a cap carbonate, the Cumberland Creek Dolostone, bear a strong lithological resemblance to the Elatina and Nuccaleena Formations. The case for correlating these neighbouring glacial units is robust (Calver, 1998; Calver and Walter, 2000; Calver et al., 2004). The King Island glacial succession plus part of the overlying Yarra Creek Shale, is intruded by a $575 \pm 4$ Ma intermediate sill from the Grimes Intrusive Suite (dated at $575 \pm 3 \mathrm{Ma}$ ) and overlain by the tholeiitic Bold Head Volcanics with a Sm-Nd age of $579 \pm 16$. At present there is no maximum constraint on the King Island glacials. However, in northwest Tasmania, the Croles Hill Diamictite, a possible correlative of the Cottons Breccia (Fig. 9.3), overlies a rhyodacite with a SHRIMP U-Pb age of $582 \pm 4$ Ma (Calver et al., 2004). There is no cap carbonate, but a thin red mudstone marks the top of the unit. If the Cottons Breccia and Croles Hill Diamictite are both correlatives of the Elatina Formation, then the Elatina Formation (and consequently the base of the Ediacaran) is c.580 Ma, about the same age as the Gaskiers Formation in North America, and the Nantuo and Ghaub Formation glaciations represent a glacial episode older than the Elatina glaciation in Australia. A c.580 Ma age for the Elatina Formation and Cottons Breccia is a better fit with the $658 \mathrm{Ma}$ age for the Merinjina Formation because a c.635 Ma age leaves little time (23 m.y. compared to 78 m.y.) to accumulate the thick upper Sturtian Stage and basal Marinoan Stage succession below the Elatina Formation (Fig. 9.1). Disparities in the acritarch record could also be explained if the Elatina Formation does not correlate with the Nantuo Diamictite. If the Elatina Formation does correlate with the Nantuo Diamictite, there has to be a large time gap (60 m.y.) between the glaciation and the Grimes Intrusive Suite, despite evidence for shallow intrusion. If this is the case, the Cottons Breccia and the Elatina Formation would be correlatives and the same age as the Nantuo and Ghaub Formations, but the Cottons Breccia 
would not be correlative with the Croles Hill Diamictite, but represent a younger glaciation (Fig. 3.1). Currently, there is no firm evidence to support one or the other interpretation.

Constraints on successions above the glaciation are poor. A $\mathrm{Rb}-\mathrm{Sr}$ whole rock isochron of $588 \pm 35 \mathrm{Ma}$ on the postglacial Bunyeroo Formation could be one of the more reliable indicators of depositional age (Preiss, 2000). The Acraman impact event has not been precisely dated but was estimated to be c.580 Ma (Williams and Gostin, 2005). However, if the Elatina Formation glaciation age is $580 \mathrm{Ma}$, then the best estimate for the age of the Acraman impact is c.570 Ma. Higher in the succession, a sedimentary zircon grain of $657 \pm 17 \mathrm{Ma}$ (similar in age to the Merinjina Tillite ash bed) places a maximum age constraint on the Marino Arkose Member. A single detrital zircon grain from the lower part of the Rawnsley Quartzite, many hundreds of metres above the glaciation and below the first bilaterians of the Ediacara fauna, dated at 556 $\pm 24 \mathrm{Ma}$, may record penecontemporaneous volcanism (Preiss, 2000), and provides the only constraint on the upper Ediacaran.

Turning to other methods of correlation, the Cryogenian part of the succession can be correlated using lithostratigraphy, stromatolite biostratigraphy and isotope chemostratigraphy, supported by palynology. Correlations between certain drill holes in the Officer Basin can be established through well-log data and seismic interpretation (Gorter et al., 2007). In addition, analyses of fully cored drill holes in the western Officer Basin, especially Empress 1A and Lancer 1, and Wallara 1 in the Amadeus Basin, confirm correlations based on field sections and other drill holes across Australia (Grey et al., 2005).

Carbon and strontium isotope curves for the Cryogenian in the Adelaide Rift Complex and Centralian Superbasin were later extended to Empress $1 \mathrm{~A}$ and Lancer 1 in the western Officer Basin and preliminary results from biostratigraphy and isotope stratigraphy were integrated in an overview of the Australian Cryogenian succession (Hill and Walter, 2000; Hill et al., 2000; Hill, 2005). The reliability of this integrated approach was further tested by examination of the biostratigraphy Wallara 1 from the Amadeus Basin.

Overlying Ediacaran successions are well correlated using both stable isotope chemostratigraphy and palynology and demonstrate what can be achieved through the application of integrated correlation methods (Grey and Calver, 2007). Biostratigraphic correlation is increasingly significant for Australian Cryogenian and Ediacaran successions and includes the use of chert microfossils, palynology and stromatolite biostratigraphy. Palynology in particular, based to a large extent on continuous core, provides good biostratigraphic control as well as indicating palaeoenvironment and thermal maturity, although much of the data remains unpublished. Cryogenian chert microfossils and palynological assemblages consist predominantly of leiospheres, filaments and mat fragments, mostly of conservative, long-ranging species with simple morphologies, but there are intervals dominated by more elaborate, shorter ranging taxa that are potential biomarkers. Several problems remain, in particular, correlation of assemblages from the Alinya Formation of the eastern Officer Basin remains uncertain. However, where acritarch and microfossil distributions in Australian successions have been studied extensively, they show consistent distribution patterns.

Similar palynological successions are present in Empress 1A and Lancer 1, and are known from several other Officer Basin drill holes. Of particular significance is the distinctive acritarch Cerebrosphaera buickii, which consistently first appears about the middle of the Hussar Formation in the western Officer Basin (Hill et al., 2000). In the Adelaide Rift Complex, it is present at about the same level in the Burra Group and has been recorded from an Emeroo Subgroup equivalent in drill hole PP 12 and the Skillogalee Dolomite (in drill hole BLD 4) in the middle of the Burra Group in the Adelaide Rift Complex (Hill et al., 2000a), above the dated (777 \pm 7 Ma) Boucaut Volcanics (Preiss, 2000). The same species was recently identified in an informally named unit above the Bitter Springs 
Formation in Wallara 1 in the Amadeus Basin.

Vase-shaped microfossils are locally abundant in chert beds in the Black River Dolomite below the Julius River Member in Tasmania (Saito et al., 1988), and are consistent with an age pre-dating the Sturtian glaciation. Although one or two specimens have been recorded elsewhere in Australia, they have not been found in any large numbers and do not appear to be widely distributed in any of the successions examined so far.

Sturtian glacial and post-glacial assemblages are poorly known throughout Australia, but are sometimes characterized by reworked fragments of Cerebrosphaera buickii. Above the level of the Elatina glaciation, the Ediacaran acritarch succession is well documented across Australia, apart from the interval immediately above the glaciation, where samples are barren. Only a handful of species survived the two major glacial episodes. Post-glacial benthic mats and leiospheres quickly reestablished and flourished as sea level and temperatures rose, but there is no obvious post-glacial species diversification; the limited species present are ones that were present before the Sturtian glaciation and there is no evidence of invasion by non-shelfal species from glacial refugia. Specimen numbers increased rapidly with rising sea level, but no new taxa were identified below the Acraman impact ejecta layer.

In Australia, a major diversification in acritarch species occurs several hundred metres above the glaciation and is associated with the second sea-level rise after the glaciation (Grey, 2005; Grey and Calver, 2007). Correlations based on palynological distributions have been tested against results from isotope chemostratigraphy, seismic interpretation, stromatolite biostratigraphy, and the appearance of the Ediacara fauna, and found to be consistent despite the poor absolute dating. In the eastern Officer Basin, the Amadeus Basin, in the Adelaide Rift Complex (and to a much lesser extent the Georgina Basin) extremely well preserved acritarch assemblages are present and are consistent across Australia (Grey, 2005; Willman et al., 2006; Willman and Moczyd_owska, 2008). The first process-bearing acanthomorphs of the Ediacaran Complex Acanthomorph Palynoflora (ECAP) do not appear until several hundred metres above the Elatina Formation glaciation and its lateral equivalents and the palynoflora seems to have been of relatively short duration, becoming extinct by c.550 Ma or even earlier.

Stromatolite biostratigraphy is based on extensive field collections, together with $>70$ horizons examined in drill core. Detailed studies of Empress 1 and 1A and Lancer 1 successions demonstrate that the drill holes can be tied to other drillholes (some of which do not have such continuous cores) and to outcrop, by means of lithostratigraphy, seismic and well log data, and isotope chemostratigraphy. In nearly all cases, the ranges shown by acritarchs and stromatolites are consistent across the various basins and correspond to the correlations determined by independent methods. These correlations can be demonstrated to apply to Cryogenian successions elsewhere in Australia (Hill et al., 2000).

The pre-Sturtian-glaciation part of the Cryogenian is characterised by two widespread but apparently time restricted stromatolite assemblages; the Acaciella australica Stromatolite Assemblage in the lower part of the succession, and the Baicalia burra Stromatolite Assemblage in the upper part of the succession (Hill et al., 2000; Grey et al., 2005; Mory and Haines, 2005). Two other assemblages, the Inzeria multiplex Stromatolite Assemblage and the Linella munyallina Stromatolite Assemblage can be recognized in the interglacial part of the succession, but so far the taxa are restricted mainly to the Adelaide Rift Complex. In addition to the stromatolites occurring in the main assemblages, several other stromatolites have been recorded at various levels throughout the Neoproterozoic of Australia but are of limited stratigraphic significance. Anabaria juvensis (=Elleria minuta) may be useful for correlating the cap carbonate, and higher in the succession, Tungussia julia allows correlation of the 
Julie Formation, the basal Bonney Sandstone and the Egan Formation.

At present, contradictions arise when global correlations are attempted, especially in matching Australian and Chinese Neoproterozoic successions based on acritarchs. Discrepancies between the two successions and the recently reported age of $658 \mathrm{Ma}$ for the Merinjina Tillite raise doubts about the Sturtian glaciation as a synchronous global event and about whether the Nantuo Tillite correlates with the Elatina Formation. Prospects for resolving these issues and for further Neoproterozoic subdivision using biostratigraphy are excellent, provided taxonomic ranges are adequately documented. Continuing improvements in biostratigraphic correlation and its integration with isotope chemostratigraphy and available geochronology, sequence stratigraphy, seismic interpretation and lithostratigraphy should enhance both hydrocarbon and mineral exploration in Neoproterozoic successions, and provide a better framework for model development for hydrocarbon prospectivity in the Officer Basin. It should also increase understanding of the stratigraphic and tectonic setting of the Centralian Superbasin and Adelaide Rift Complex.

Finally, in considering a suitable point for a basal Cryogenian GSSP, it is necessary to pick a boundary that stands a reasonable chance of being identified globally. The older Cryogenian in Australia, although characterized by the Acaciella australica assemblage is still too poorly documented elsewhere in the world to be used as a suitable base. In Australia, there are significant gaps in the succession, or the succession is known only in drillholes. Moreover, many researchers investigating the positioning of the GSSP have expressed the view that this should be a geological period characterised by glaciation. Where the c.830-800 Ma interval has been documented, it seems to be dominated by an arid climate, and it is at least another 75 million years (nearly as long an interval as the Cretaceous Period, the longest of the Phanerozoic periods) before glaciation becomes widespread. It would be better to establish the boundary closer to the glaciation, and the near coincidence between the first appearances of $B$. burra, C. buickii, and a major carbon isotope excursion may be a much more appropriate position for the boundary.

\section{Acknowledgments}

Kathleen Grey publishes with the permission of the Executive Director, Geological Survey of Western Australia. Clive Calver and Andrew Hill and many other colleagues have provided invaluable discussions on relation to this topic. This paper is a contribution to IGCP Projects 493 - Vendian Biota and 512 Neoproterozoic ice ages. Kath Grey is an associate researcher at Monash University.

\section{References}

Calver, C.R. (1998). Isotope stratigraphy of the Neoproterozoic Togari Group, Tasmania. Australian Journal of Earth Sciences 45, 865-874.

Calver, C.R., Walter, M.R. (2000). The late Neoproterozoic Grassy Group of King Island, Tasmania: correlation and palaeogeographic significance. Precambrian Research 100, 299-312.

Calver, C.R., Black, L.P., Everard, J.L., Seymour, D.B. (2004). U-Pb zircon age constraints on late Neoproterozoic glaciation in Tasmania. Geology 32, 893-896.

Fanning, C.M., Link, P. (2006). Constraints on the timing of the Sturtian glaciation from southern Australia; i.e. for the true Sturtian. Geological Society of America Philadelphia Annual Meeting, Paper No. 42-6 (abstract) .

Gorter, J., Grey, K., Hocking, R.M. (2007). The petroleum exploration potential of the Australian Infracambrian (Ediacaran) of the Amadeus and Officer Basins. Australian Petroleum Production and Exploration Association (APPEA), 391-392.

Grey, K. (2005). Ediacaran Palynology of Australia. Memoir of the Association of Australasian Palaeontologists 31, 439p.

Grey, K, Calver, C.R. (2007). Correlating the Ediacaran of Australia, in The Rise and Fall of the Ediacaran Biota (edited by P Vickers-Rich and P Komarower). The Geological Society of London Special Publication 286, 115-135. 
Grey, K., Hocking, R.M., Stevens, M.K, Bagas, L, Carlsen, G.M., Irimies, F, Pirajno, F, Haines, P.W., Apak, S.N. (2005). Lithostratigraphic nomenclature of the Officer Basin and correlative parts of the Paterson Orogen, Western Australia. Western Australia Geological Survey Report 93, 89p.

Haines, P.W., Hocking, R.M., Grey, K., Stevens, M.K (2008). Vines 1 revisited: are older Neoproterozoic glacial deposits preserved in Western Australia? Australian Journal of Earth Sciences 55, 397-406.

Hill, A.C. (2005). Stable isotope stratigraphy, GSWA Lancer 1, Officer Basin, Western Australia in Mory, A.J. and Haines, P.W. (eds), GSWA Lancer 1 Well completion report (interpretive papers), Officer and Gunbarrel Basins, Western Australia. Geological Survey of Western Australia Record 2005/4, 1-11.

Hill, A.C., Walter, M.R. (2000). Mid-Neoproterozoic ( 830-750 Ma) isotope stratigraphy of Australia and global correlation. Precambrian Research, 100, 181-211.

Hill, A.C., Cotter, K.L., Grey, K. (2000). Mid-Neoproterozoic biostratigraphy and isotope stratigraphy in Australia. Precambrian Research, 100, 283-300.

Mory, A.J., Haines, P.W. (2005). GSWA Lancer 1 well completion report (interpretive papers), Officer and Gunbarrel Basins, Western Australia. Geological Survey of Western Australia Record 2005/4, 90p.

Preiss, W.V. (2000). The Adelaide Geosyncline of South Australia and its significance in Neoproterozoic continental reconstruction. Precambrian Research, 100, 21-63.

Saito, Y., Tiba, T., Matsubara, S. (1988). Precambrian and Cambrian cherts in northwestern Tasmania. Bulletin of the National Science Museum, Series C. Geology and Paleontology, National Science Museum, Tokyo 14, 59-70.

Williams, G.E., Gostin, V.A. (2005). Acraman - Bunyeroo impact event (Ediacaran), South Australia, and environmental consequences: twenty-five years on. Australian Journal of Earth Sciences 52, 607-620.

Williams, G.E., Gostin, V.A., McKirdy, D.M., Preiss, W.V. (2008). The Elatina glaciation, late Cryogenian (Marinoan Epoch), South Australia: Sedimentary facies and palaeoenvironments. Precambrian Research 163, 307-331.

Willman, S. Moczyd_owska, M. (2008). Ediacaran acritarch biota from the Giles 1 drillhole, Officer Basin, Australia, and its potential for biostratigraphic correlation. Precambrian Research 162, 498-530.

Willman, S., Moczyd_owska, M., Grey, K. (2006). Neoproterozoic (Ediacaran) diversification of acritarchs - A new record from the Murnaroo 1 drillcore, eastern Officer Basin, Australia. Review of Palaeobotany and Palynology 139, 17-39. 
NOTES: 


\section{Ediacarans on the Edge: Environmental Controls on Diversity of the Ediacara biota}

Gehling, James G.

South Australian Museum, North Terrace, Adelaide, South Australia, 5000, Australia

gehling.jim@saugov.sa.gov.au

\author{
Biography:
}

Jim Gehling has a BSc (Hons), MSc (Adelaide) and PhD (UCLA). He is a Senior Research Scientist, working on Ediacaran and Cambrian fossils funded by ARC. Designed Mesozoic and Ediacara and Cambrian sections of the Fossil Gallery, SA Museum. Chairman, Neoproterozoic Subcommission, ICS. Previously, he was a senior lecturer, Earth Sciences, University of South Australia, and research fellow Queen's University, Ontario.

The Global Stratigraphic Section and Point (GSSP) for the Ediacaran Period is defined at the base of the Nuccaleena Formation in the Flinders Ranges of South Australia (Knoll, et al., 2006). Since there is no reliable geochronology for constraining the age of fossils of the Ediacara biota in Australia, we must use stable isotopes, event stratigraphy and biostratigraphy for correlation with other Ediacaran successions. One of the objectives of our research is to determine ranges and taxonomic diversity of the local assemblages of the Ediacara biota for comparisons with the better-constrained assemblages on other continents.

The fossil record of the Ediacaran Period can be divided into two epochs. The first half (635-580Ma) features low diversity, organic-wall microfossils in most successions with a few larger spinose forms in South China. In southern Australia, the Acraman impart event appears just below the base of the late epoch (580-542Ma) that features several zones of large spinose acritarchs below as-yet poorly constrained megascopic fossil zones of the Ediacara biota. The base of the Cambrian is clearly defined by the near coincidence of penetrative trace fossils and small shelly fossils, as well as the taphonomic loss and extinction of most elements of the Ediacara biota.

Recent chemostratigraphic analyses of Ediacaran successions (Fike et al., 2006; Canfield et al., 2007) have demonstrated a progressive increase in free oxygen at the base of the late Ediacaran epoch and an inferred decrease in dissolved organic carbon (DOC) in shallow marine settings. This might explain a progressive shift from assemblages dominated by large, sessile multicellular organisms to those featuring motile Ediacarans that left locomotion and feeding traces, followed by the first simple skeletal fossils at the end of the Ediacaran.

Unlike South Australia, assemblages of the Ediacara biota in Russia, England, Newfoundland, Namibia and China are bracketed using zircon U-Pb dates from volcanic ash beds. Ediacaran megafossil assemblages cluster into the Avalon association (575-560 Ma) of discoidal forms and rangeomorphs from Newfoundland and England, the White Sea association ( 560-550 Ma) of rangeomorphs, stem-group bilaterians and trace fossils from Russia and Siberia, the Nama association ( $\sim 550-542 \mathrm{Ma})$ of rangeomorphs, trace fossils and calcified tubes and cups from Namibia and western North America (Narbonne, 2005), and the Yangtze association (551-542 Ma) of metaphytes and trace fossils from China and Siberia. The megafossil assemblages from South Australia cluster with the White Sea Association (Waggoner, 2003), despite being the most widely separated regions in most reconstructions of Ediacaran continental fragments. In all recent continental reconstruction during the Ediacaran there are palaeobiogeographic anomalies with Ediacara fossil associations. The global distribution of Ediacara index fossils argues against Phanerozoic style provincialism. 


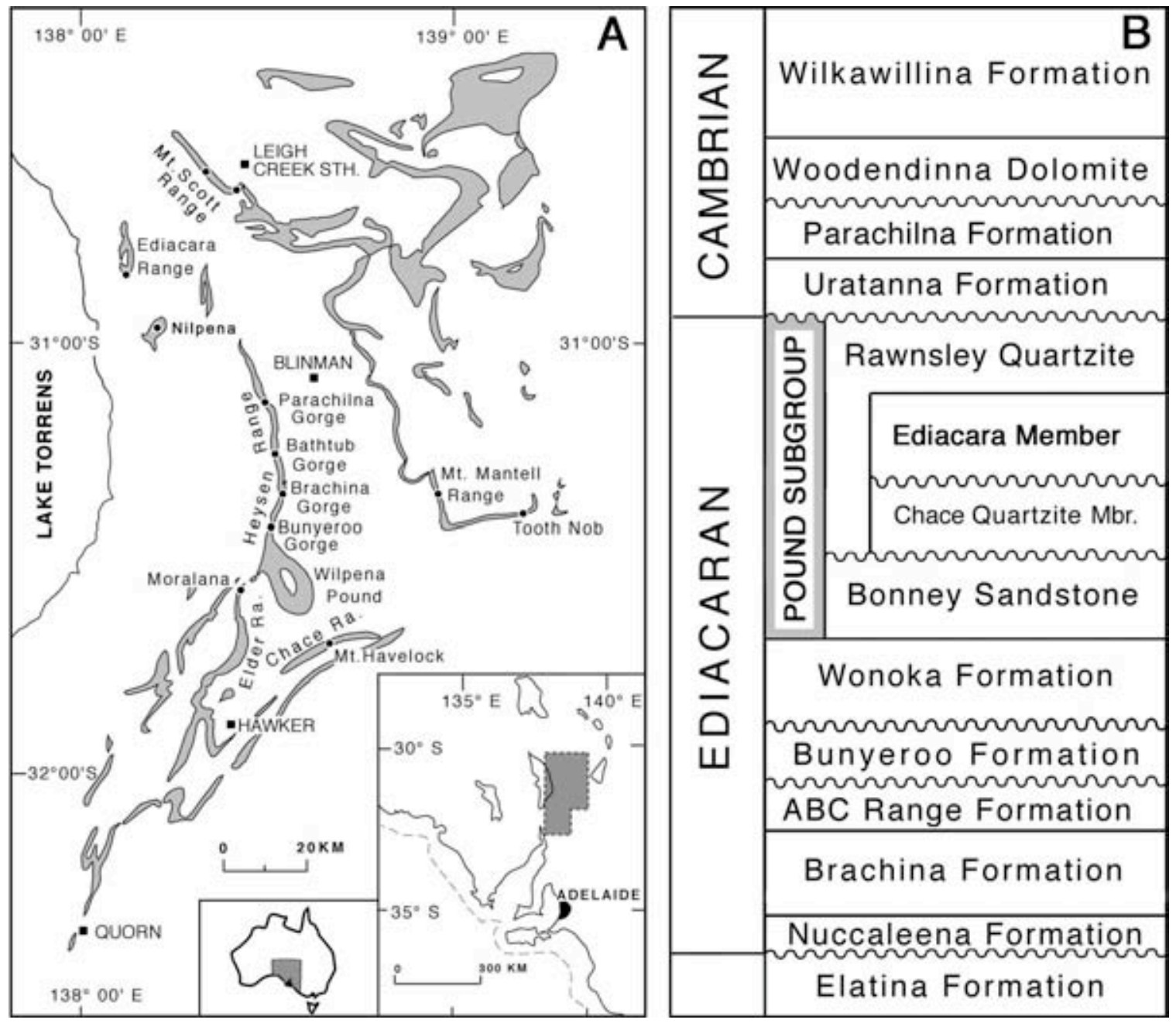

Fig. 4.1. A. Location map, outcrop of the Pound Subgroup, Rawnsley Quartzite and Bonney Sandstone. B. Generalized Ediacaran and Early Cambrian stratigraphy in the Flinders Ranges, South Australia.

Recent palaeoecological studies of the Ediacara biota in the Late Ediacaran, Rawnsley Quartzite of the Flinders Ranges in South Australia (Fig. 4.1), demonstrate remarkable variations in the diversity of assemblages from suites of beds situated within relatively small stratigraphic and geographic ranges. On the western margins of the Flinders Ranges, wave-ripple topped, sandy event beds accumulated below fair-weather wave base, smothering samples of benthic communities of Ediacara organisms (Gehling, 1999). The distribution and orientation of body fossil impressions indicated communities established during fair-weather intervals. Size distributions and associations suggest that each bed records a different opportunistic colonization by common taxa of the Ediacara biota including a variety of textured organic surfaces (TOS) (Droser \& Gehling, 2008; Gehling \& Droser, in press), benthic motile and sessile bilaterian grade organisms and frond-like organisms of cnidarian or sponge grade that were attached by discoidal holdfasts (Droser et al., 2006). While vertical heterogeneity has been demonstrated for successive beds, the overall assemblage is relatively uniform in particular sedimentary facies. However, lateral facies changes are accompanied by contrasting fossil assemblages and styles of preservation.

Fossil assemblages, preserved between fair-weather and storm wave base, occur on the shoulders of submarine canyons cut 100-300 m into both the underlying Chace Quartzite Member of the Rawnsley Quartzite and the Bonney Sandstone (Gehling, 2000). Although largely filled with mass-flow sands, canyons include some allochthonous blocks of the Ediacara Member. In the upper parts of canyons, large fragmented fronds, bag-shaped forms, and fractal plumes, occur within massive sandstones deposited as mass-flow or slumped sands. These are capped by well-bedded sandstones bearing 
bioclasts and sandy event beds lacking wave ripples. Thicker event beds preserve single-species dominated assemblages on the bed soles.

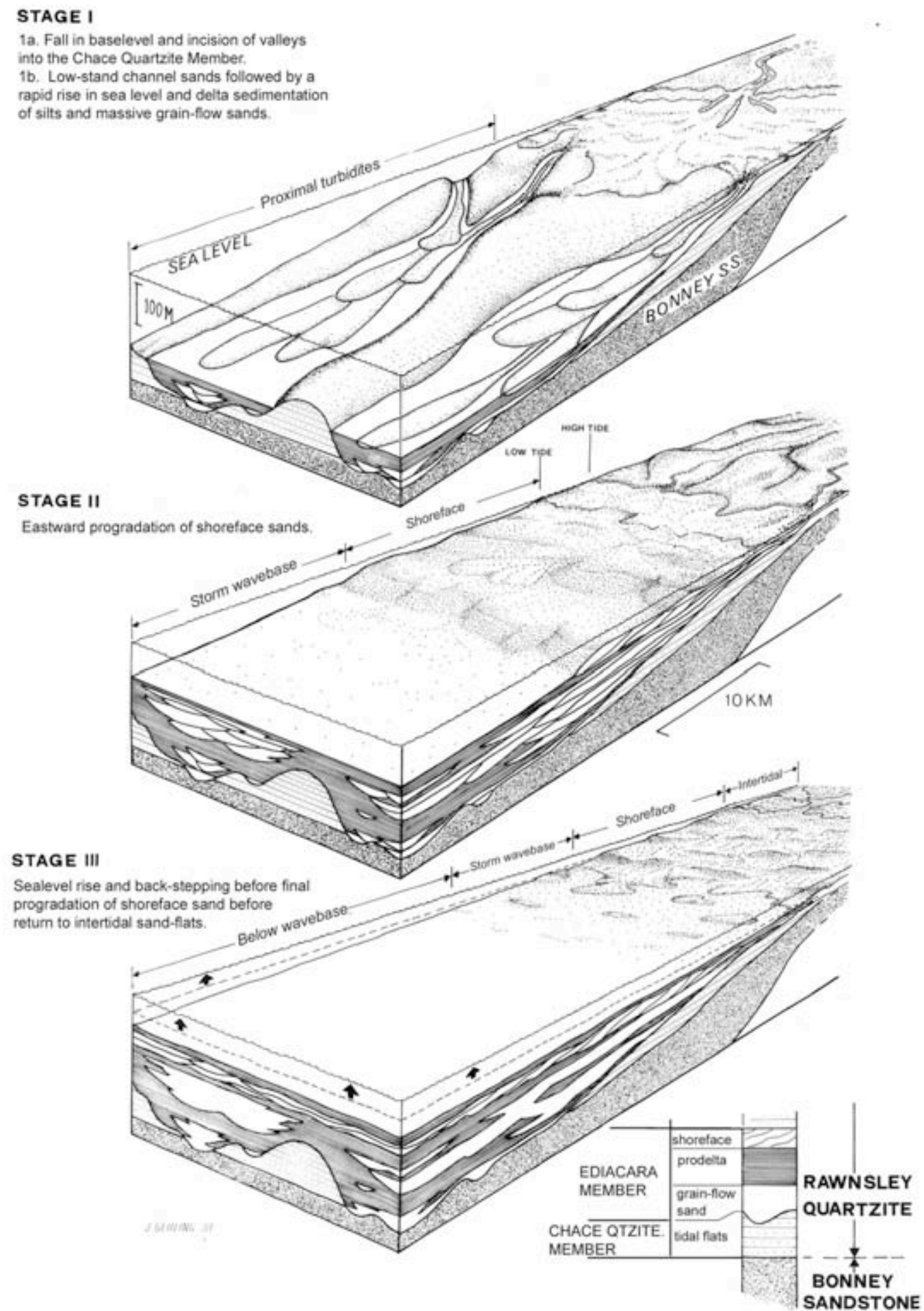

Fig. 4.2. Environmental interpretation of the late Ediacaran Ediacara Member, Rawnsley Quartzite, Flinders Ranges South Australia.

In the shallower facies of the Ediacara Member, species density and diversity varies laterally, as sampled from outcrop nearest the palaeo-shoreline, on the western margins of the Flinders Ranges, and further out into the basin, from the N-S Heysen Range and Elder Range, and the SW-NE trending Chace Range (Fig 4.1). The richest fossil beds apparently accumulated on the shoulders of submarine canyons close to the collapsed margins. Traced away from the canyon margins, identical facies show 
greatly reduced numbers of body fossils and diversity of TOS, suggesting a strong influence by submarine topography.

These examples of rich Ediacara mega-fossil assemblages in contrasting sandy-facies represent the juxtaposition of shallow-water communities and microbial mat grounds with submarine canyon edge and canyon-fill facies that preserve in situ and transported Ediacara organisms, respectively. Holdfasts and shredded stalks in shallower facies suggest that erect fronds were once present, but were torn away during storm events and transported into deeper water. Where such fronds were partly filled with sand during transport, they were re-sedimented within mass-flow beds that filled the canyons, together with various other three-dimensional forms.

The recognition of various local fossil assemblages associated with differing depositional environments, presents some problems when trying to determine the age range of the Ediacara biota in South Australia by comparison with taxa distinguished form age constrained successions elsewhere. Ediacara mega fossil taxa, previously thought to be confined to Newfoundland, England, Namibia and China, have now been identified in various depositional settings within the Ediacara Member of South Australia. As first argued by Grazhdankin (2004), it appears that assemblages are strongly dependant on local marine settings, palaeo-climatic belts and sedimentary tectonic factors, rather than simply representing a evolutionary changes in the Ediacara biota with temporal significance.

Although environmental factors appear to have strongly influenced the diversity of Ediacaran megafossil assemblages around the globe, it is the appearance, after $560 \mathrm{Ma}$, of trace fossils and bilaterian body fossil assemblages of the White Sea and Nama associations that distinguishes them from the older Avalon association.

\section{References}

Canfield, D.E., Poulton, S.W., Narbonne, G.M. (2007). Late-Neoproterozoic deep-ocean oxidation and the rise of animal life. Science 315, 92-95.

Droser, M.L., Gehling, J.G. (2008). Reproduction and synchronous aggregate growth in a new Ediacaran tubular organism. Science 319, 1660-1662.

Droser, M.L., Gehling, J.G., Jensen, S.R. (2005). Ediacaran trace fossils: true and false. In: D.E.G. Briggs (editor), Evolving Form and Function: Fossils and Development. Peabody Museum of Natural History, Yale University. pp. 125-138.

Droser, M.L., Gehling, J.G., Jensen, S.R. (2006). Assemblage palaeoecology of the Ediacara biota: The unabridged edition. Palaeogeography, Palaeoclimatology, Palaeoecology. 232, 131-147.

Fike, D.A., Grotzinger, J.P., Pratt, L.M., Summons, R.E. (2006). Oxidation of the Ediacaran ocean. Nature 444, $744-747$.

Gehling, J.G., 1999. Microbial mats in terminal Proterozoic siliciclastics: Ediacaran death masks. Palaios14, 40-57.

Gehling, J.G. (2000). Sequence stratigraphic context of the Ediacara Member, Rawnsley Quartzite, South Australia: a taphonomic window into the Neoproterozoic biosphere. Precambrian Research 100, 65-95.

Gehling, J.G., Droser, M.L., (in review) Textured organic surfaces associated with the Ediacara biota in South Australia. In: N. Noffke, (editor) Microbial mats. Earth Science Reviews.

Gehling, J.G., Droser, M.L., Jensen, S.R., Runnegar, B.N. (2005). Ediacaran organisms: relating form and function. In: D.E.G. Briggs (Editor). Evolving Form and Function: Fossils and Development. Peabody Museum of Natural History, Yale University. pp. 43-67.

Gehling, J.G., Narbonne, G.M., Anderson, M.M. (2000). The first named Ediacaran body fossil: Aspidella: terranovica Billings 1872. Palaeontology 43, 427-456.

Grazhdankin, D. (2004). Patterns of distribution in the Ediacaran biotas: facies versus biogeography and evolution. Paleobiology 30, 203-221.

Knoll, A.H., Walter, M.R., Narbonne, G.M., and Christie-Blick, N. (2006). The Ediacaran Period: a new addition to the geological time scale. Lethaia 39, 13-30.

Narbonne, G.M. 2005. The Ediacara biota: Neoproterozoic origin of animals and their ecosystems. Annual Reviews of Earth and Planetary Sciences 33, 13.1-13.22.

Waggoner, B. (2003) The Ediacaran biotas in space and time. Integrative and Comparative Biology 43, 104-113. 


\section{Giant Cryogenian reefs as windows into pre-Ediacaran Life}

Malcolm W. Wallace

\&

Estee Woon

School of Earth Sciences, The University of Melbourne Victoria 3010.

mww@unimelb.edu.au e.woon@pgrad.unimelb.edu.au
Biography:

\begin{abstract}
Malcolm Wallace completed a $\mathrm{PhD}$ in 1988 at the University of Tasmania on Devonian Reefs of the Canning Basin. He had a Research Fellowship (19881991) on Acraman impact ejecta. Presently (1991-2008) he is an Associate Professor and Reader at University of Melbourne. In 2008 he will receive the 2008 Selwyn Medal (for nomination see abstract 13, this volume)
\end{abstract}

Estee Woon is undertaking $\mathrm{PhD}$ research (2005-2008) on Cryogenian reefs of the Flinders Ranges at the University of Melbourne

The sudden and widespread appearance of soft-bodied metazoan organisms during the Late Neoproterozoic ( 600-544 My BP) and the later development of organisms with hard-mineralised skeletons at the beginning of the Cambrian (the Cambrian Explosion 544 My BP) are events that challenge our understanding of early life. The relatively sudden appearance of these advanced organisms in the geological record and the lack of ancestral precursors has focussed attention on the period of time preceding the Ediacaran (prior to $\sim 620 \mathrm{My} \mathrm{BP})$. A series of large Cryogenian ( $\sim 650$ My BP) reef complexes discovered in the Flinders Ranges (South Australia) provide a rare window into this pre-Ediacaran world. We present a previously undescribed assemblage of calcified organisms and show that the complexity of these Cryogenian reef-building organisms is comparable to Phanerozoic metazoans.

Neoproterozoic reefs allow a rare window into the foundations of organic calcification and skeletonization by providing an ideal environment for the calcification of organisms. The latest Ediacaran ( 543-548 Ma) Nama Group reefs, for example, host numerous calcified metazoans and microbes that predate the base of the Cambrian (Grotzinger et al. 2000). However, the record of Neoproterozoic calcified organisms is extremely sparse, with the remarkable Little Dal reefs (1100$780 \mathrm{Ma})$ representing the only other examples of large-scale Neoproterozoic calcimicrobial reefs (Aitken, 1988; Batten et al, 2004). By contrast, older Proterozoic reefs consist almost entirely of stromatolites and thrombolites.

The reef complexes described here occur within the Umberatana Group in the northern Adelaide Geosyncline of South Australia (Fig. 1). The reefs are of late Sturtian to early Marinoan age (late Cryogenian), overlying Sturtian diamictites and underlying Marinoan glacigene sediments. A reef margin, previously referred to as a "submarine escarpment" (Coats, R. P. \& Blissett, 1971; Preiss, 1987), is well exposed near Oodnaminta Hut (Fig. 1). Other reef complexes are present near Arkaroola and Mt Serle. The platforms consist of dolomite of the Balcanoona Formation that is laterally equivalent to the basinal Tapley Hill Formation calcareous and dolomitic shales (Coats, R. P. $\&$ Blissett, 1971; Priess, 1987). There are few direct geochronological constraints on the age of the Umberatana Group, but Fanning (2006) reported a U-Pb zircon age of $658 \mathrm{Ma}$ from a tuffaceous horizon within the uppermost Sturtian diamictites. The age of the Marinoan glacial event, represented by the Elatina Formation, can be tentatively placed at 635 Ma by correlation with the Ghaub Formation in Namibia (Hoffmann et al., 2004). 


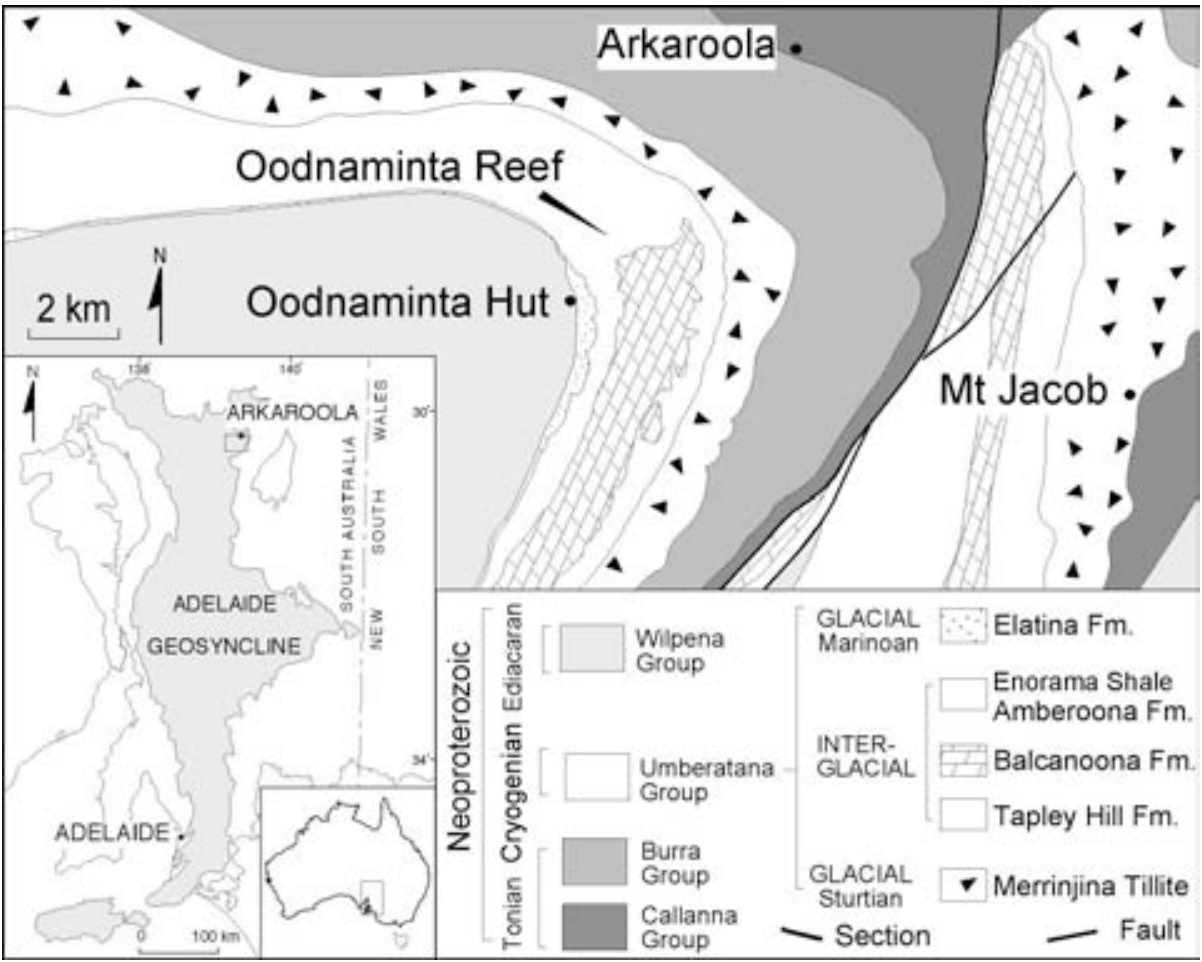

Fig. 5.1. Geologic, stratigraphic and locality diagram with location of the Oodnaminta reef

The reef complexes (platform, reef margin and slope) consist entirely of dolomite. The dolomite has mimetically replaced the primary calcium carbonate sediments and much of the sedimentary microstructure is preserved. In contrast, allochthonous blocks and megabreccias preserved in the basinal shales consist of undolomitized and dolomitized limestone. The undolomitized and partially dolomitized allochthonous material of the basin generally better preserves the primary depositional fabrics of the reef (and proves the reefs were originally precipitated as calcite).

The Oodnaminta reef (Fig. 5.1) consists of a high-energy platform facies, underlain by a massive reef margin facies. The uppermost portion of reef margin facies consists of stromatolitic frameworks, while the lower, deeper water portion of the reef margin consists of a non-stromatolitic organic framework (Fig. 5.2). Underlying this non-stromatolitic framework facies are allochthonous breccias of the lower slope. The breccia facies directly overlies and interdigitates with the basinal calcareous shales of the Tapley Hill Formation. Basinal shales contain large allochthonous blocks and megabreccias shed from the reef margin. The regional and internal geometry of the platform indicates a strongly progradational reef history, with the platform margin having advanced at least $12 \mathrm{~km}$ as exposed in continuous outcrop.

The well-bedded dolomites of the Oodnaminta platform facies attain a total thickness of $300 \mathrm{~m}$ and consist predominantly of fenestral ooid and peloid grainstones. Laminoid fenestrae range from millimetre-size structures and grade into large scale sheet cavities (centimetres high and metres long). Sheet cavities are larger and more dominant towards the platform margin, where they commonly occur with small-scale tepee structures (typically $30 \mathrm{~cm}$ wide and $10 \mathrm{~cm}$ high). Fenestrae and sheet cavities are filled by isopachous fibrous cements that have both fascicular-optic and radial-fibrous fabrics (Kendall, 1985). The fibrous cements are most abundant towards the platform margins. 


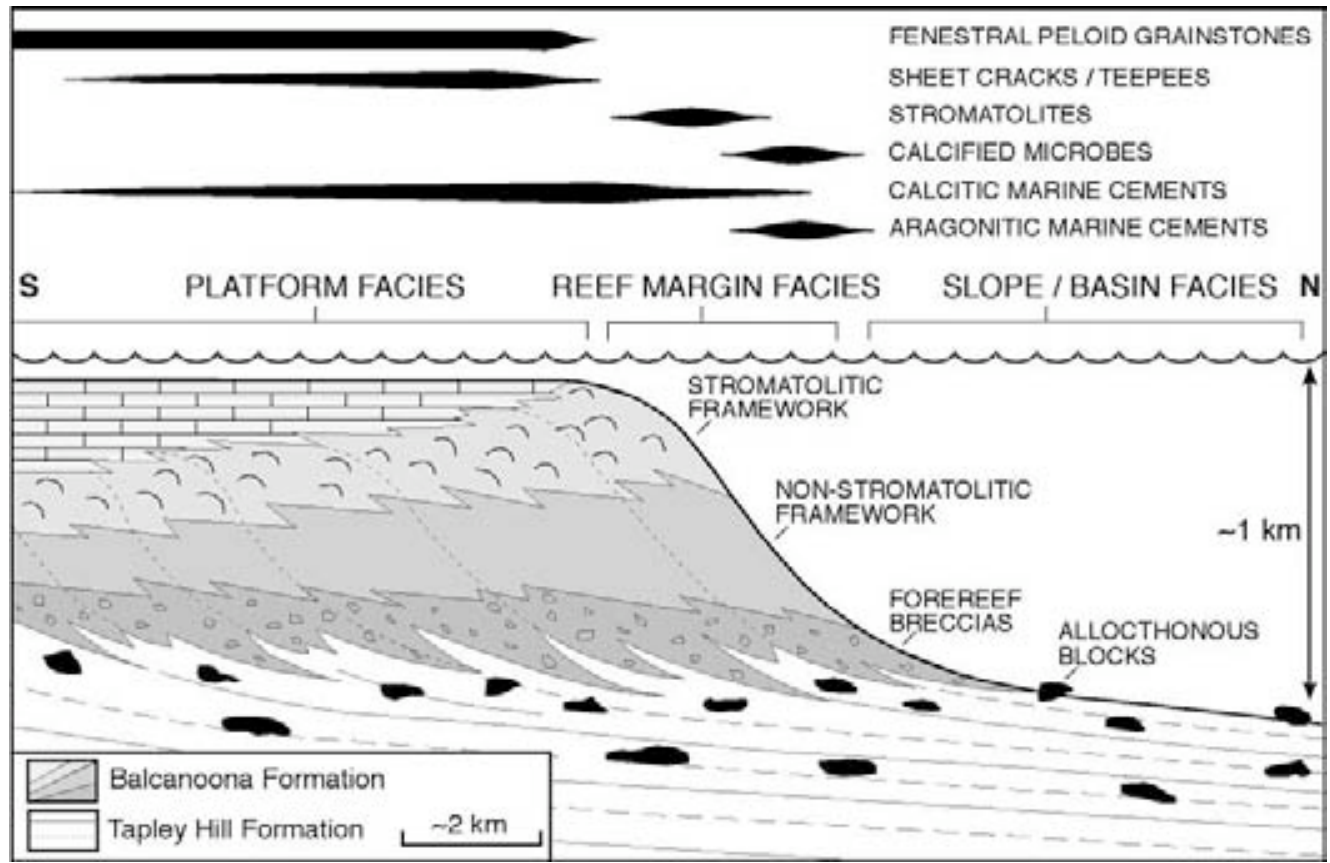

Fig. 5.2. Diagrammatic representation (to approximate scale) of the Oodnaminta reef, showing the major facies and sedimentological features of the complex.

The stromatolitic framework facies ranges from $\sim 160$ to $\sim 350 \mathrm{~m}$ in stratigraphic thickness. The stromatolites are characterised by low relief columns and domes that are typically several centimetres wide. Where discernable, the growth direction is invariably basinwards. The stromatolites consist of micrite and microspar, and have a variety of microfabrics, including laminated micritic (generally wavy lamination), microdendritic, microfenestrate, and "structure grumeleuse" fabric. Large cavities of any type are uncommon within the stromatolite facies, except where transitions with the underlying organic framestones occur.

The non-stromatolitic framework facies ranges from $\sim 100$ to $\sim 400 \mathrm{~m}$ in stratigraphic thickness and is characterised by an abundance of growth cavities, the cavities ranging from millimetres to centimetres in size. The cavities are generally filled by fibrous cements (radial fibrous and fascicular optic texture) or coarse equant-poikilitic cement. The non-stromatolitic framework contains several forms of calcified fossils. The most distinctive calcified organism has rounded or vesicular chambers that encrust one another, the morphology being reminiscent of some chambered sphinctozoan sponges (Fig. 5.3). Another fossil has a dendritic texture at outcrop scale and has a polygonal chambered microfabric, with the chamber walls consisting of dolomicrite.
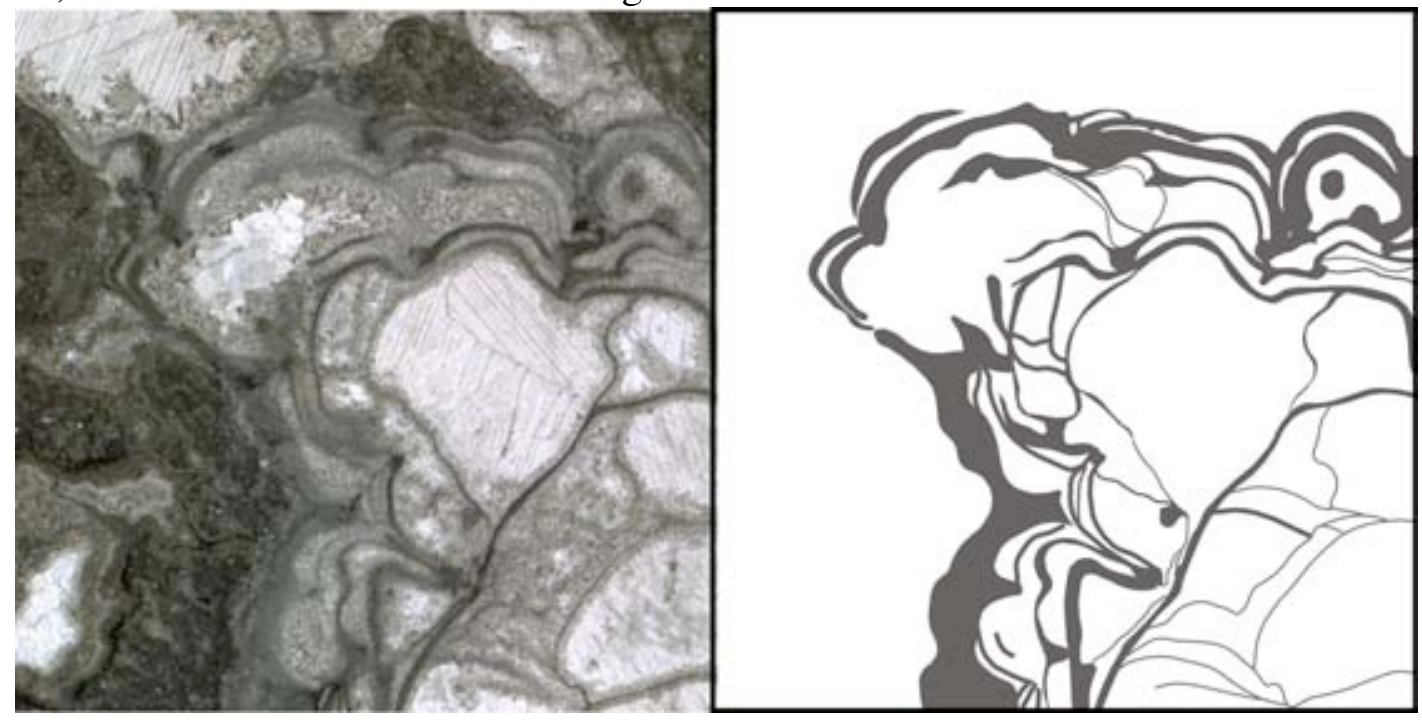

Fig. 5.3. Chambered vesicular fossil that has a structure reminiscent of chambered sponges. Field of view $10 \mathrm{~mm}$. 
Micritic carbonate shrubs (cf Fraiser and Corsetti, 2003) are also a common component within the non-stromatolitic framework facies and these are generally intergrown with other microbial constituents. The carbonate shrubs consist of micrite and resemble features described previously from the Little Dal reef as pendent clot microstructure (Turner et al. 1993) and suggested to be similar to renalcids.

Intergrowth of these calcified organisms results in a large variety of fabrics including massive, cavernous and thrombolitic frameworks. Growth cavities within the frameworks commonly contain pendent calcified microbes, indicating that the cavities were host to coelobiontic organisms. In undolomitized allochthonous blocks, the abundant growth cavities commonly contain fascicular optic and radial fibrous calcite cements. However, many growth cavities are filled by equant-poikilitic calcite with pseudomorphic textures after radiating aragonite botryoids.

Paleo-water depths for the various reef facies can be estimated using the base of the platform facies as a proxy for sea level. This assumes that the outer edge of the platform facies was approximately at sea level and would result in minimum depth estimates. Using measured stratigraphic thicknesses from the base of the platform facies indicates that the stromatolitic framework facies probably grew in water depths ranging from 20 to $350 \mathrm{~m}$. The non-stromatolitic framework facies probably grew in depths from 180 to $700 \mathrm{~m}$. These depth estimates indicate that all of the non-stromatolitic framework facies (and some of the stromatolitic facies) grew in sub-photic zone depths, indicating a nonphotosynthetic origin.

The non-stromatolitic framework of this Cryogenian reefs displays a suite of remarkably complex calcified organisms and shares many of the features of modern and Phanerozoic reef systems, despite its great age. The general complexity and diversity of the Oodnaminta fossils suggests an evolutionary advancement over the older Little Dal reefs of Northwest Canada (Aitken, 1988; Batten et al, 2004). Like the Oodnaminta reef, the Little Dal reefs have organisms that apparently grew in relatively deep water (Batten et al, 2004).

Significantly, the Oodnaminta reef complexes contain fossils that have features in common metazoans. The vesicular chambered fossil has a relatively regular arrangement of primary and secondary chambers that resemble some Phanerozoic sponges. Silicified examples of these fossils also display a series of regularly spaced depressions on the surface that resemble ostia in sponges. We therefore suggest the possibility that these fossils may be archaic sponges. This suggestion would not be at odds with phylogenomic data that suggest that sponges, cnidarians and ctenophores are the oldest multicellular animals (Dunn et al. 2008). The interpreted timing of sponge evolution from molecular clock techniques (Hedges et al. 2006) is also consistent with the existence of Cryogenian sponges.

\section{References}

Aitken, J.D. 1988. Giant 'algal' reefs, middle/upper Proterozoic Little Dal Group (<770, <1200 Ma), Mackenzie Mountains, N.W.T., Canada. In: Reefs, Canada and Adjacent Area: Canadian Society of Petroleum Geologists Memoir (Eds H.H.J. Geldsetzer, N.P. James and G.E. Tebbutt), 13, pp. 13-23. Canadian Society of Petroleum Geologists Memoir.

Batten, K.L., Narbonne, G.M. and James, N.P. 2004. Paleoenvironments and growth of early Neoproterozoic calcimicrobial reefs: platformal Little Dal Group, northwestern Canada. Precambrian Research, 133: 249-269.

Coats, R.P. and Blissett, A.H. 1971. Regional and economic geology of the Mount Painter Province, 43. Department of Mines Geological Survey of South Australia, Adelaide.

Corsetti, F.A. and Fraiser, M.L. 2003. Neoproterozoic Carbonate Shrubs: Interplay of Microbial Activity and Unusual Environmental Conditions in Post-Snowball Earth Oceans. Palaios, 18: 378-387.

Dunn, C.W., Hejnol, A., Matus, D.Q., Pang, K., Browne, W.E., Smith, S.A., Seaver, E., Rouse, G.W., Obst, M., Edgecombe, G.D., Sorensen, M.V., Haddock, S.H., Schmidt-Rhaesa, A., Okusu, A., Kristensen, R.M., Wheeler, W.C., Martindale, M.Q. and Giribet, G. 2008. Broad phylogenomic sampling improves resolution of the animal tree 
of life. Nature, 452: 745-749.

Fanning, C.M. and Link, P.K. 2006. Constraints on the timing of the Sturtian glaciation from Southern Australia: i.e. for the true Sturtian. In: 2006 Philadelphia Annual Meeting (22-25 October 2006), pp. paper \# 42-6, Philadelphia, Pennsylvania.

Grotzinger, J.P., Watters, W.A. and Knoll, A.H. 2000. Calcified metazoans in thrombolite-stromatolite reefs of the terminal Proterozoic Nama Group, Namibia. Paleobiology, 26: 334-259.

Hedges, S.B., Battistuzzi, F.U. and Blair, J.E.M., 2006. Molecular Timescale of Evolution in the Proterozoic. In: Neoproterozoic Geobiology and Paleobiology (Eds S. Xiao and A.J. Kaufman), pp. 199-229. Springer, New York.

Hoffmann, K.H., Condon, D.J., Bowring, S.A. and Crowley, J.L. 2004. U-Pb zircon date from the Neoproterozoic Ghaub Formation, Namibia: Constraints on Marinoan glaciation. Geology, 32: 817-820.

Kendall, A.C. 1985. Radiaxial fibrous calcite: a reappraisal. In: Carbonate Cements (Eds N. Schneidermann and P.M. Harris), pp. 59-77. SEPM Special Publication No. 36, Tulsa, OK.

Preiss, W.V.C., R.P. Forbes, B.G. 1987. The Adelaide Geosyncline: Late Proterozoic stratigraphy, sedimentation, palaeontology and Tectonics. Bulletin of the Geological survey of South Australia, 53.

Turner, E.C., Narbonne, G.M. and James, N.P. 1993. Neoproterozoic reef microstructures from the Little Dal Group, northwestern Canada. Geology, 21: 259-262. 
NOTES: 


\section{Evidence for large glacioeustatic changes associated with the 635-Ma glaciation in Namibia}

Paul F. Hoffman

Dept of Earth and Planetary Sciences, Harvard University, Cambridge, MA 02138, USA and

Geology \& Geophysics, School of Earth \& Environmental Sciences, The University of Adelaide, SA 5005, Australia
Biography:

A Canadian field geologist, Paul Hoffman pioneered the application of plate tectonics to Proterozoic orogenic belts, the assembly of Laurentia and the succession of supercontinents before Pangea. He has also studied carbonate sedimentary facies before skeletal organisms and the pan-glacial climate cycle known as snowball earth.

\section{paulfhoffman@yahoo.com}

Climate models (Donnadieu et al., 2003; Pollard \& Kasting, 2004) suggest that continental ice sheets would have grown to a global average thickness of $\sim 3000 \mathrm{~m}$ within several $100 \mathrm{kyr}$ after the inception of a snowball earth, fed by sublimation of subtropical sea ice. This implies a glacioeustatic fall of $\sim 1500 \mathrm{~m}$, which has nowhere been reported. Why not?

Pleistocene glacioeustasy $(\sim 130 \mathrm{~m})$ has been inferred from drowned coral reefs and wave-cut terraces on ocean islands unaffected by glacioisostatic adjustments. If ice sheets covered all continents, the problem is not so straightforward (Fig. 6.1). Given a $3000 \mathrm{~m}$ ice load, the $1500 \mathrm{~m}$ glacioeustatic fall will be offset by (1) 808 m of glacioisostatic adjustment, (2) $455 \mathrm{~m}$ of hydroisostatic adjustment of the seafloor, (3) $\sim 60 \mathrm{~m}$ of near-field sea-level rise caused by gravitational attraction to the ice sheet itself, and (4) synglacial tectonic subsidence (e.g., $\sim 145 \mathrm{~m}$ stratigraphically inferred for the Otavi carbonate platform in Namibia). The resulting net change in base-level (i.e., relative sea-level) is only $32 \mathrm{~m}$ (1500-808-455-60-145 m). If the ice thickness at the margin is only $1000 \mathrm{~m}$, however, and the average ice-sheet thickness is unchanged (Fig. 6.1), the net base-level fall will be $\sim 607 \mathrm{~m} \mathrm{(1500-273-}$ 455-20-145 m). New observations from the Otavi carbonate platform in northern Namibia (Fig. 6.2) are compatible with a 600-m fluctuation in base level (Hoffman, 2005; Hoffman et al., 2007).

$\begin{array}{lrc}\text { ice thickness (*at margin) } & 3000 & 1000^{*} \\ \text { glacioeustasy } & -1500 & -1500 \\ \text { glacioisostasy } & +808 & +273^{*} \\ \text { hydroisostasy } & +455 & +455 \\ \text { gravitational pull } & \sim+60 & \sim+20^{*} \\ \text { tectonic subsidence } & +145 & +145 \\ \text { glacio+hydro+grav+tec } & +1468 & +893^{*} \\ \text { net base-level change } & -32 & -607^{*}\end{array}$

Prior to glaciation, a marine shallow-water carbonate platform covered the southern promontory of the Congo craton. The southern edge of the platform is contiguous with a distally-tapered slope wedge, extending to paleodepths of $>1.0 \mathrm{~km}$ (Fig. 6.3), based on analogous modern slope profiles like the western flank of the Great Bahama Bank or the northwest Australian continental margin. Glacioeustatic fall related to ice-sheet buildup at higher latitudes is manifested exposure of the platform and deposition of a low-stand wedge on the slope. The low-stand wedge is a coarseningupward sequence of carbonate turbidites and debris flows, characterized by slabs of very coarse- 
grained oolite (Franni-aus Member). The oolite is unknown on the platform and is inferred to have originally formed at the falling strand-line on the slope. Lowering of the strand-line resulted in mass wasting and gravitational redeposition of the weakly-cemented oolite as debris flows. The oolite was completely removed from the upper slope by subsequent glacial erosion.

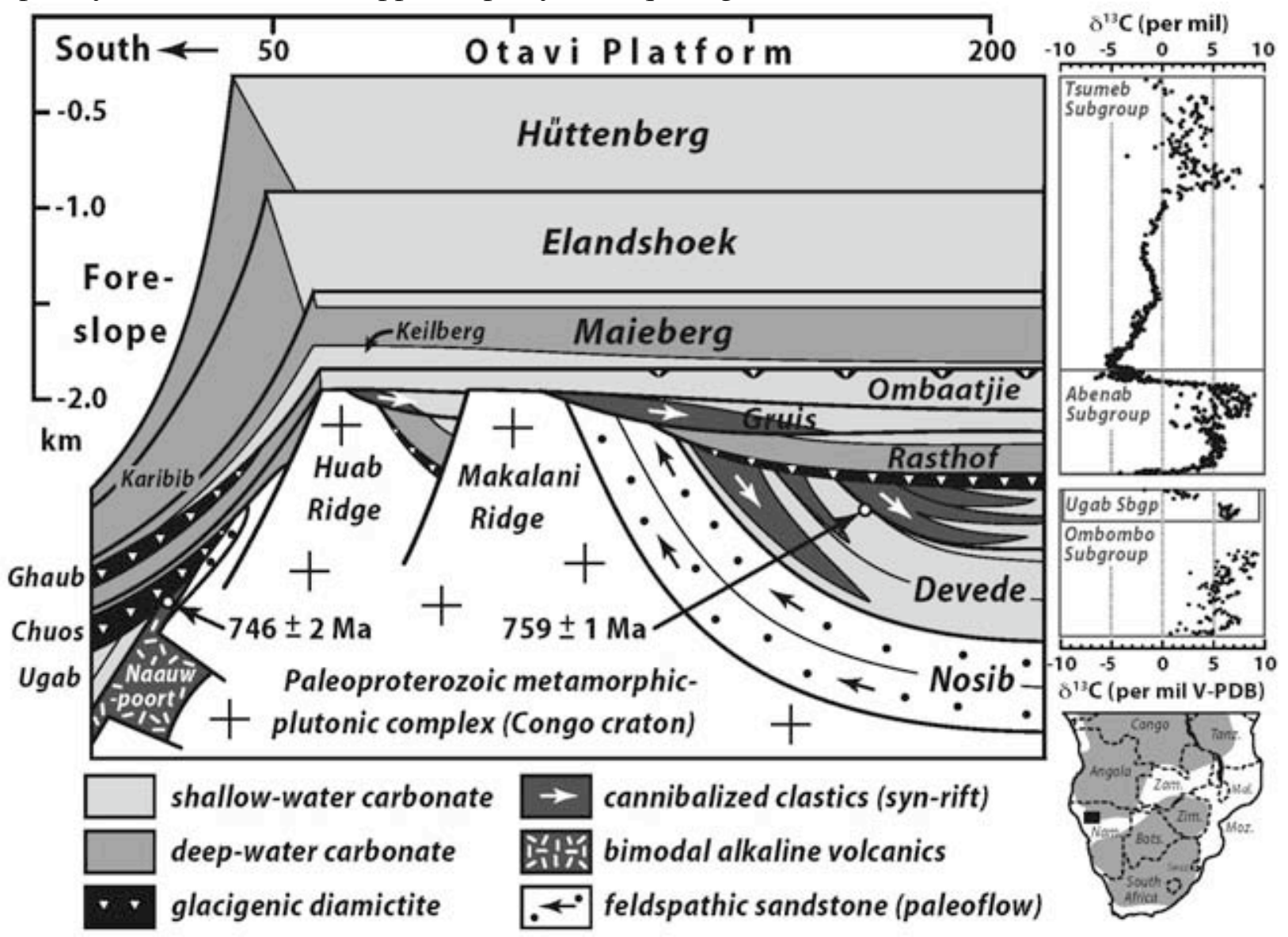

Fig. 6.2. North-south stratigraphic cross-section of the Otavi Group carbonate platform (770-580 Ma), northern Namibia.

On the platform, the subglacial erosion surface has a raised outer rim, devoid of glacial deposits, and a bowl-shaped interior with local rises (Fig. 6.3). Veneers of lodgement tillite occur in the interior and relics of carbonate aeolianite on the outer rim. The upper slope is also devoid of glacial deposits, but on the lower slope ( $>500 \mathrm{~m}$ paleodepth), there is a continuous prism ( $100 \mathrm{~m}$ thick) composed of intertongued glacial and subaqueous proglacial carbonate debris (Ghaub Formation). The prism is dominated by poorly-stratified, carbonate-clast diamictites, interpreted variably as ice-contact and proximal rain-out deposits. Thin proglacial tongues consist of well-stratified suspension fallout with ice-rafted debris (IRD), turbidites, debris-flows, westerly-directed contourites, and localized sands and sandy gravels interpreted as grounding-line fans.

In one area, the sub-Ghaub erosion surface cuts a steep-walled transverse trough (100 m deep by 20 $\mathrm{km}$ wide) defined by removal of underlying strata (Fig. 6.4). It was likely cut by an ice-stream draining the platform. The prism thins into the trough, but a steep, doubly-crested, moraine-like ridge of unstratified diamictite stands at the median. IRD implies the existence of an ice margin (contra snowball), but terrigenous siltstone in basal extra-trough Ghaub strata required glacial down-cutting for their derivation. This suggests that the Ghaub formed late in the glacial episode, post-dating the incision of the trough. The existence of open water during deglaciation is not surprising and does not preclude a prior ice-covered ocean. 


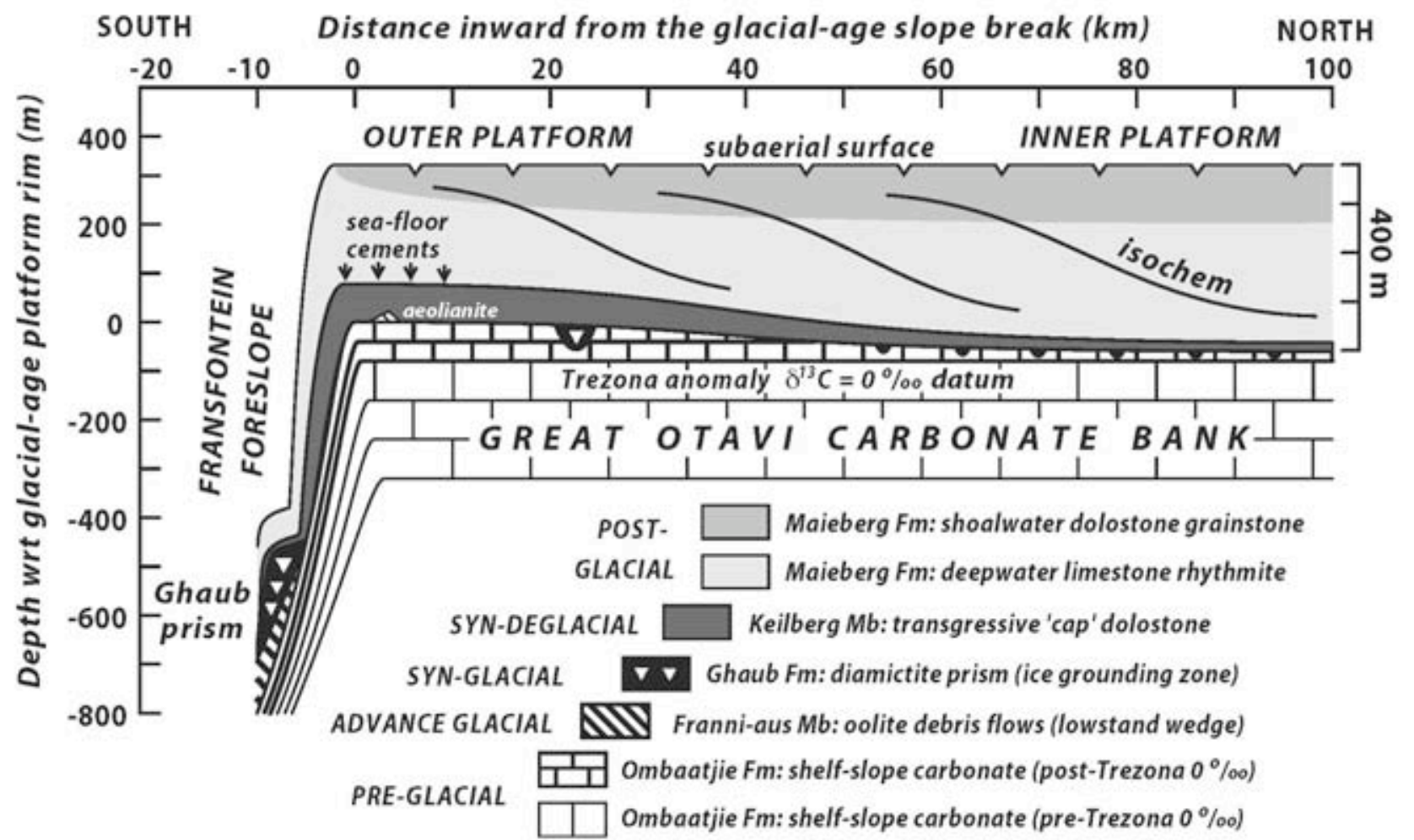

Fig. 6.3. Stratigraphic-paleobathymetric reconstruction of the Otavi carbonate platform and foreslope around the time of the Ghaub glaciation $(635 \mathrm{Ma})$. Note position of the Ghaub ice-grounding zone prism $450-650 \mathrm{~m}$ below the rim of the platform, assuming a slope profile similar to that of the western margin of the Great Bahama Bank.

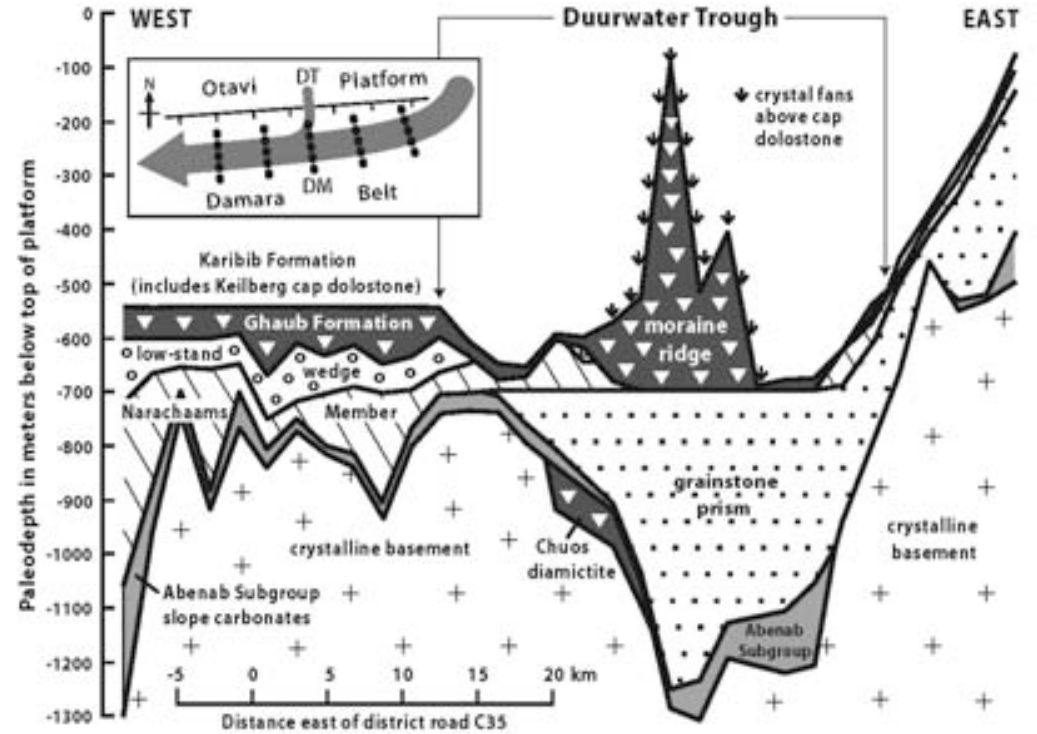

Fig. 6.4. East-west contour parallel stratigraphic section of the Otavi Group lower slope at the end of the $635 \mathrm{Ma}$ Ghaub glaciation. Eastern end of the section angles obliquely up the foreslope toward the platform margin. A transverse ice-streamlet is thought responsible for the Duurwater trough and moraine.

The prism was deposited along a quasi-stable ice grounding-line situated at paleodepths of 500-800 m below the rim of the platform (Fig. 6.3). This implies very thick ice and/or large base-level fall. Support for a large glacioeustatic component comes from the well-developed low-stand wedge on the lower slope beneath the prism, and from wave-generated structures in the "cap" dolostone above the prism or the equivalent erosion surface in all areas. No other unit contains wave-generated structures (sorted macropeloids, low-angle cross-lamination, giant wave ripples) on the lower slope. The presence of wave-generated structures in the cap dolostone in all areas along with systematic variations in carbon-isotope profiles indicates diachronous deposition during glacioeustatic flooding. When shallow-water deposition occurred on the lower slope, the top of the platform was above sealevel; when shallow-water deposition occurred on the platform, the lower slope was well below wave- 
base. Following glacioeustatic flooding, the platform was submerged below storm wave-base even after isostatic adjustment. A base-level rise of $>500 \mathrm{~m}$ is therefore unavoidable, assuming the inferred paleobathymetric profile is realistic. After glacioeustatic flooding, the platform filled up to sea-level with carbonate sediment diachronously from the outer rim northward into the platform interior (Fig. 6.3).

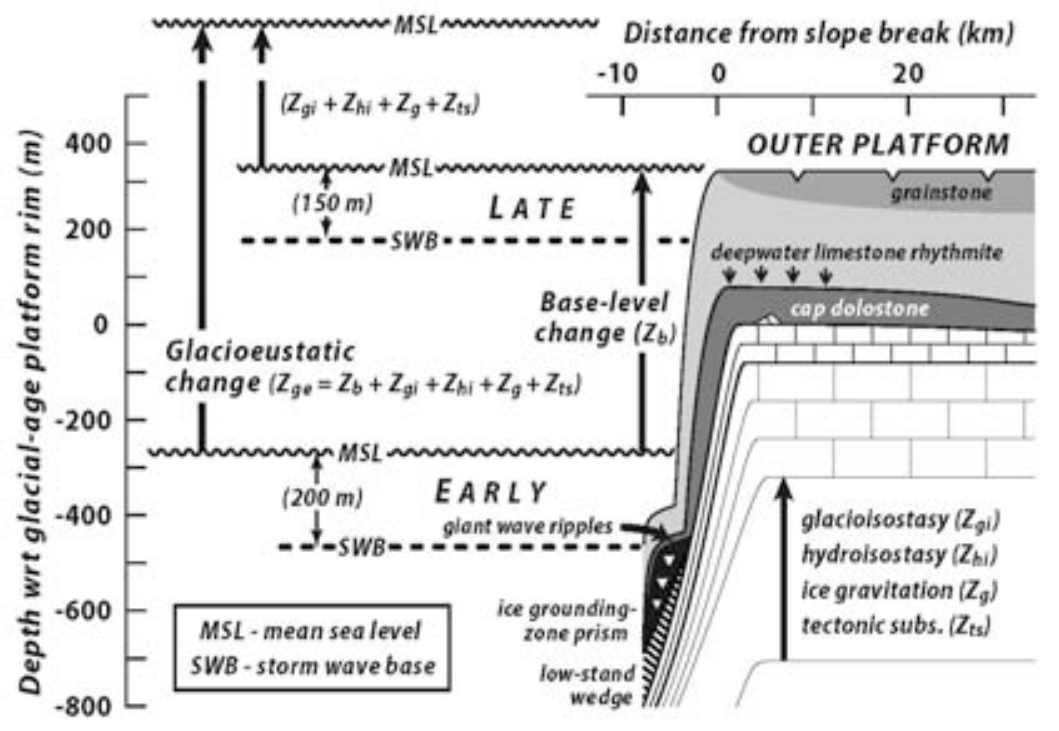

Fig. 6.5. Reconstructed base-level and inferred glacio-eustatic changes associated with the termination of the Ghaub glaciation in Namibia.
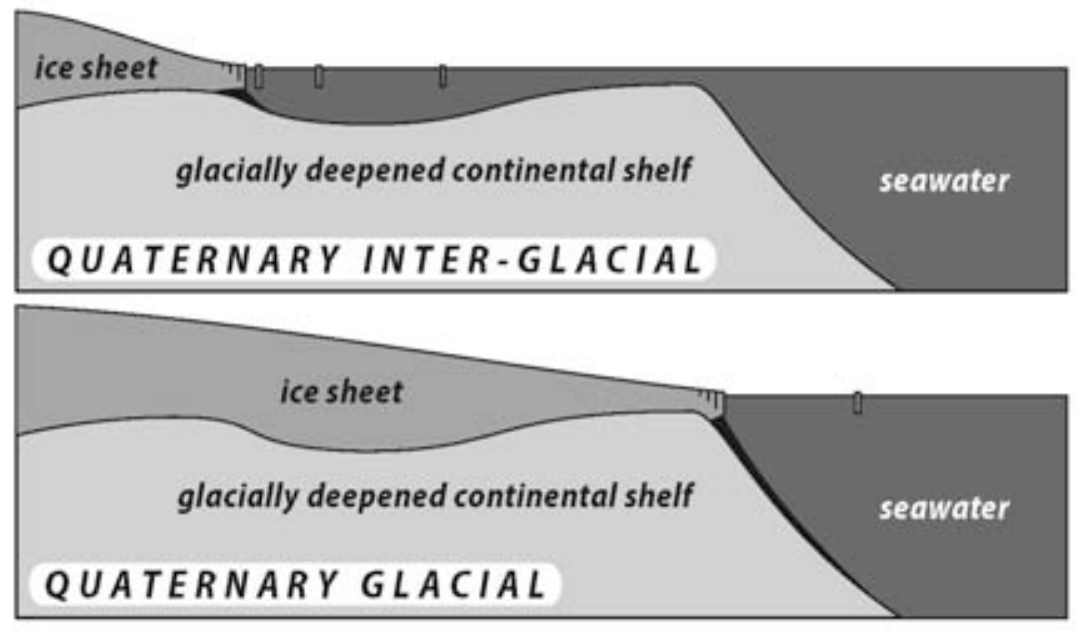

Fig. 6.6. Contrast in location of ice grounding-line prisms between Quaternary inter-glacial and glacial periods, and the end-Cryogenian panglacial location as inferred for the Ghaub grounding-line prism in northern Namibia.

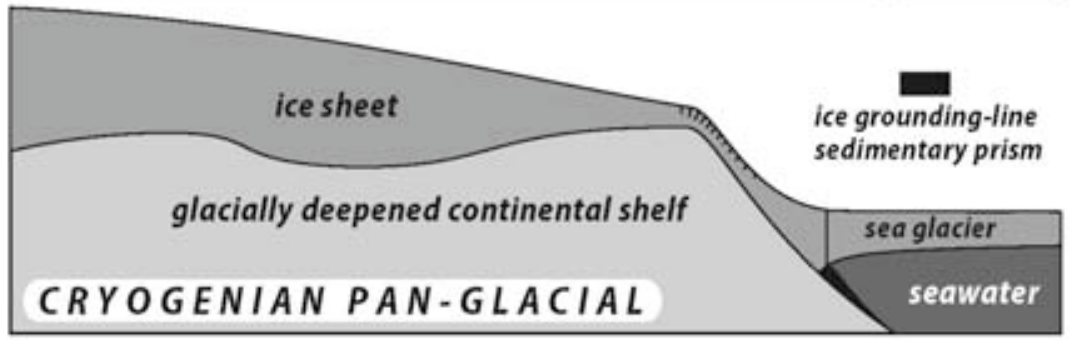

Lithologically, the Ghaub Formation closely resembles ice grounding-line prisms of Quaternary age in Polar seas, except for its detrital carbonate composition. However, Quaternary grounding-line prisms alternated between outer-shelf and inner-shelf locations during glacial-interglacial cycles. The lowerslope location of the Ghaub grounding-line prism is dramatically different. Sedimentological comparison alone fosters the mistaken inference that Quaternary and Cryogenian glaciations were broadly similar. The paleogeographic setting of the Ghaub grounding-line deposits implies $\sim 600 \mathrm{~m}$ of base-level fall, compatible with $\sim 1500$ m of glacioeustasy, more than 10x greater than the Quaternary. 


\section{References}

Donnadieu, Y., Fluteau, F., Ramstein, G., Ritz, C., Besse, J. (2003) Is there a conflict between the Neoproterozoic glacial deposits and the snowball Earth interpretation: an improved understanding with numerical modeling. Earth and Planetary Science Letters 208, 101-112.

Pollard, D., Kasting, J.F. (2004) Climate-ice sheet simulations of Neoproterozoic glaciation before and after collapse to Snowball Earth. In: Jenkins, G.S., McMenamin, M.A.S., McKay, C.P., \& Sohl, L. (eds.) The Extreme Proterozoic: Geology, Geochemistry, and Climate. Geophysical Monograph 146, American Geophysical Union, Washington, DC., 91-105.

Hoffman, P.F. (2005) $28^{\text {th }}$ DeBeers Alex. Du Toit Memorial Lecture: On Cryogenian (Neoproterozoic) ice-sheet dynamics and the limitations of the glacial sedimentary record. South African Journal of Geology 108, 557-576.

Hoffman, P.F., Halverson, G.P., Domack, E.W., Husson, J.M., Higgins, J.A., Schrag, D.P. (2007) Are basal Ediacaran (635 Ma) post-glacial "cap dolostones" diachronous? Earth and Planetary Science Letters 258, 114-131. 
NOTES: 


\section{The tectonic and palaeogeographic setting of Australia's Neoproterozoic rock record}

Wolfgang V. Preiss

Geological Survey Branch

PIRSA GPO Box 1671 Adelaide

South Australia 5001

\section{Biography:}

Wolfgang completed a Ph.D. on South Australian Precambrian and Cambrian stromatolites at Adelaide University in 1971. He then joined the Geological Survey of SA and has published extensively on Neoproterozoic and Cambrian stratigraphy and tectonics

preiss.wolfgang@saugov.sa.gov.au

Like that of many other continents, Australia's Neoproterozoic rock record provides evidence of extreme climatic changes, protracted tectonic reorganisation on a global scale, and the evolution of complex life. That record is preserved in the sedimentary successions of epicratonic basins (platforms), intracontinental rift and sag basins, and evolving passive margins, as the fragments of Rodinia split and separated (Fig. 7.1).

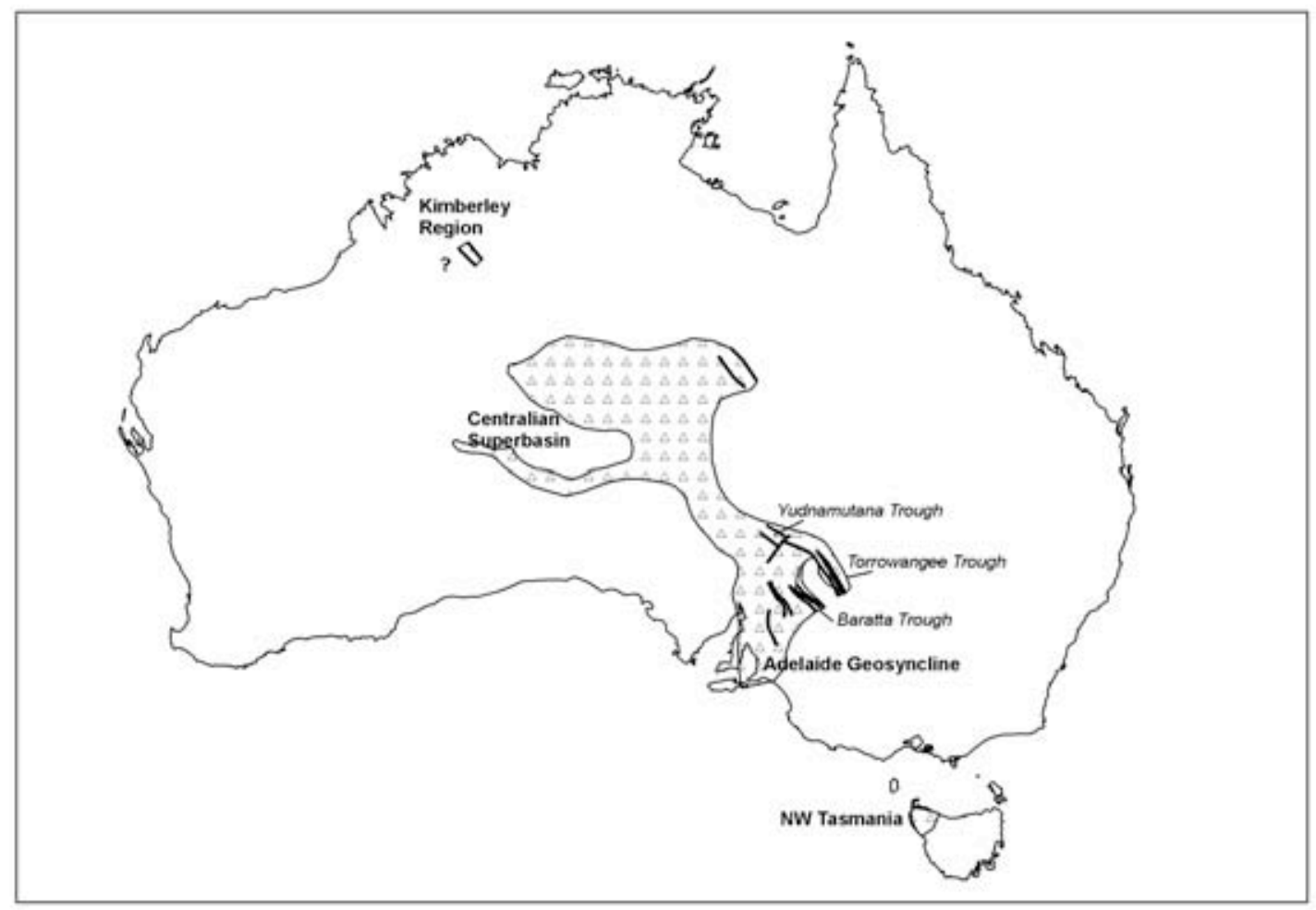

Fig. 7.1. A snapshot in the palaeogeographic evolution of Australia during the Sturt glaciation immediately before the inferred onset of Rodinia break-up.

The earliest Neoproterozoic Period (Tonian, 1000-850 Ma) is possibly represented in Australia only in the sediments of the Yeneena Basin, Western Australia. Elsewhere a long erosional interval at this time was followed by the evolution of the basins that contain the main Neoproterozoic record and form the topic of this paper: the Centralian Superbasin (Walter et al., 1995), Kimberley Region (Coats and Preiss, 1980), Adelaide Geosyncline (Preiss, 2000) and northwest Tasmania (Calver, 1998). These basins have all been considerably modified and fragmented by Phanerozoic tectonic events, which at the same time have ensured their accessibility to direct observation though uplift and partial erosion.

Advances in understanding of the Australian Neoproterozoic record over the last four decades have resulted from field mapping and drilling programmes, detailed stratigraphic and sedimentological studies, geochronology, palaeontology, isotope geochemistry, palaeomagnetism and tectonic 
synthesis. There is now broad agreement regarding stratigraphic correlation between the various preservational basins, and only a few, relatively minor uncertainties remain, although the precise calibration of the record against a tightly constrained timescale has not yet been achieved, due largely to the paucity of datable volcanic units. Detailed correlation with Neoproterozoic successions on other continents remains contentious.

The stratigraphic consensus is used here to reconstruct the palaeogeographic evolution of the Australian portion of Rodinia during its long break-up history spanning Cryogenian, Ediacaran and Cambrian times. The chronostratigraphic terms Willouran, Torrensian, Sturtian, Marinoan and Ediacaran, based on type sections in South Australia where the record is most complete, provide a relative time framework within which the Neoproterozoic history of Australia can be discussed, involving the following stages:

- Sedimentation commenced in early Willouran time with a large intracontinental, terrestrial to shallow marine sag basin, the Centralian Superbasin, situated in the southern part of the Northern Territory, eastern Western Australia and northern South Australia. Early extensive sand sheet sedimentation gave way to stromatolitic carbonates. Given the location of this basin in the centre of a supercontinent, its access to the open sea is unknown.

- The first evidence of large-scale Willouran continental extension comes in the form of NWtrending mafic dykes and their extrusive equivalents at $827 \mathrm{Ma}$ (Wingate et al., 1998). These dykes cut cratonic basement complexes of the Gawler Craton, Curnamona Province and Musgrave Province; in eastern South Australia their inferred extensions now lie deeply buried beneath the $\sim 15 \mathrm{~km}$ thick succession of the Adelaide Geosyncline.

- Late Willouran ( 800 Ma) carbonate and evaporitic sedimentation continued in the Centralian Superbasin but, in South Australia, renewed NE-SW extension produced a series of NWtrending graben filled with mixed clastic, carbonate and evaporitic sediments and minor mafic and felsic volcanics.

- In early Torrensian time (< 780 Ma), the sea had withdrawn from most of the Centralian Superbasin, though stromatolitic carbonate deposition continued in its southwestern portion. In contrast, renewed continental extension in South Australia led to a wider zone of rifting, horst and graben structures, and a well-defined, N-S trending eastern rifted margin of the Gawler Craton. Basal coarse-grained and immature terrestrial clastic sediments and minor mafic (and possibly felsic) volcanics accumulated in the rifts while overlying carbonates and fine-grained clastics suggest incipient marine transgression.

- Mid-Torrensian time saw widespread paralic stromatolitic carbonate deposition, characterised by essentially primary fine-grained dolomite and sedimentary magnesite (with only rare modern analogues). Clastic influx was still important at western and northeastern basin margins. Locally, incipient diapirism caused by gravitational instability of Willouran evaporitic sediments influenced sedimentation. Similar carbonates were deposited in Tasmania perhaps at this time, though the palaeogeographic relationship of this crustal block to mainland Australia during the Neoproterozoic is uncertain.

- Deeper marine transgression into the rifts of the Adelaide Geosyncline in late Torrensian time brought extensive silt and deeper water dolomite deposition, punctuated by a series of sandy deltas prograding into the basin from the Gawler Craton in the west.

- The beginning of Sturtian time is marked by renewed influx of coarse-grained feldspathic detritus after a brief erosional break. Ensuing deeper water silt deposition and deltaic sand progradation were similar to those of late Torrensian time, but the presence of extremely rare lonestones may be a distant echo of glaciation elsewhere.

- Significant tectonic movements in mid-Sturtian time coincided with the onset of the Sturt glaciation. There was further extensional faulting, diapirism, and variable erosion of 
underlying rock packages, both in the Centralian Superbasin and in the Adelaide Geosyncline, and the glacial successions everywhere unconformably overlie the older rocks.

- Mid-Sturtian glacial sedimentation commenced with diamictite, conglomerate and dropstone facies in the deepest part of the Yudnamutana Trough, a partly fault-bounded and glacially sculpted valley in the northeast Flinders Ranges, SA. Glaciomarine diamictite deposition then spread quickly across the whole Adelaide Geosyncline and most of the Centralian Superbasin (Fig. 1), where the deposits are relatively thin. Glacial sediments are mostly absent on the Gawler Craton, and may have been very thin or never deposited there, but their thickness increases gradually up to a few hundred metres across the western shelf region of the Adelaide Geosyncline. The locus of extension shifted eastward at this time, producing the NW-trending Baratta, Yudnamutana and Torrowangee Troughs, which together define the limits of the Curnamona Province basement. Sedimentary ironstones are confined to the Baratta Trough. Similar NW-trending fault troughs of Sturtian age occur in the southern Georgina Basin, but the age of a local glacial graben fill in the Kimberley Region is controversial. All Sturtian rifts accumulated thick glaciomarine deposits, the upper parts of which are deeper water silts and sands with persistent dropstones representing gradual deglaciation at $\sim 660 \mathrm{Ma}$, recently dated by a thin volcaniclastic layer (Fanning and Link, 2006). Local diamictite in Tasmania may also relate to the Sturt glaciation (Calver, 1998).

- Late Sturtian post-glacial sedimentation ( 650 Ma) commenced with marine transgression over a peneplained surface on the glacial sediments, erosion perhaps caused by isostatic rebound. For the first time, transgression spread significantly onto the Gawler Craton. The fine-grained organic-rich sediments are uniform over large areas, including parts of the Centralian Superbasin. The change in tectonic style suggests that this may have been the time of incipient continental separation, a new passive margin appearing somewhere in present day Victoria and NSW as a result of the Sturtian phase of continental extension. The base of the post-glacial succession may therefore represent a break-up unconformity. Sm-Nd isotopes also indicate a different provenance for these sediments, with a more juvenile input (Barovich and Foden, 2000).

- Late Sturtian highstand deposition led to progradation of ooid shoals and stromatolitic bioherms, mainly along the western and northeastern margins of the Adelaide Geosyncline, and finally withdrawal of the sea and local erosion.

- Renewed transgression in earliest Marinoan time deposited supratidal dolomite in marginal zones of the Adelaide Geosyncline and sand in the depocentre, followed by silt deposition. Overall sea-level was lower than in the late Sturtian highstand, with discrete facies belts paralic redbeds at the western and northeastern basin margins and grey sandy silts further offshore. Oolitic, stromatolitic and sandy limestones interfinger with silty sediments, and are also represented locally in the eastern Centralian Superbasin. A second early Marinoan transgression and highstand in the Adelaide Geosyncline and saw water depths approaching those of the late Sturtian. Diapirism continued to affect sedimentation.

- Deposits of the Elatina glaciation, of mid-Marinoan age (?635-580 Ma), are extremely widespread in the Adelaide Geosyncline and Centralian Superbasin, mostly disconformably overlying various older rocks. In the deepest water part of the new passive margin succession in the southeastern Adelaide Geosyncline the gradual incoming of glacial dropstones in laminated siltstone heralded the onset of glaciation. In this region, and in the northern Flinders Ranges, the glacial deposits include glaciomarine diamictite and dropstone facies of greygreen colour. Elsewhere, the shelf regions of the Adelaide Geosyncline and Centralian Superbasin are dominated by reddish sandstone, and red siltstone with rare glacial clasts, and lenticular red diamictite. The Gawler Craton was terrestrial at this time, with aeolian sand interfingering eastward with glacial outwash and diamictite.

- Post-glacial transgressive deposits with a distinctive basal cap dolomite mark the beginning of the Ediacaran Period. As with the Sturt glaciation, isostatic rebound may have caused 
peneplanation of the glacial sediments. Grey-green and red-brown silt deposition was widespread across all basins during the ensuing highstand, culminating in sandy deltas sourced probably from distant parts of the Gawler Craton.

- A second Ediacaran transgression flooded the whole Adelaide Geosyncline and Centralian Superbasin, depositing widespread red mudstone. A thin debris layer not far above the base, attributed to bolide impact on the Gawler Craton, has been recognised hundreds of kilometres from the interpreted impact site.

- The late Ediacaran Period heralded major tectonic, sedimentologic and biotic changes. In the Adelaide Geosyncline, a thin but persistent dolomite separates the red mudstone from an overlying dominantly calcareous silty succession characterised by deep syndepositional incisions variously interpreted as submarine canyons or drowned river valleys. Whatever their origin, they involved sudden deepening of erosional base level during one or multiple downcutting events, accompanied by slumping and mass wasting. At about the same time $(\sim 580$ Ma), a thick pile of mafic volcanics was extruded near the eastern Australian passive margin in NSW and Tasmania, and represents a renewed phase of extension and perhaps accelerated break-up, which may have facilitated canyon incision. Deeper-water mudstone deposition continued in the Centralian Superbasin, culminating in shallow-water stromatolitic carbonate.

- In the Harts Ranges region near the southeastern limit of the Centralian Superbasin, a probable dextral pull-apart basin developed in the late Neoproterozoic, possibly related to the same tectonism. Extreme burial and intrusion of mafic magmas led to very high grade early Palaeozoic metamorphism of the Neoproterozoic and Cambrian sedimentary fill of this entirely intracontinental rift (Maidment et al., 2004).

- Toward the end of the Ediacaran, the Centralian Superbasin underwent radical change. Uplift of the Musgrave Province as a result of the Petermann Range Orogeny led to segmentation of the superbasin into separate depocentres with the characteristics of foreland basins. Firstly, coarse clastic detritus was shed southward into the deep-water mudstone environment in what is now the Officer Basin, then redbed sand deposits spread northward into the present Amadeus and Ngalia Basins. At the same time, sedimentation in the Adelaide Geosyncline contracted to the region of the present Flinders Ranges, with deposition of red and white sands containing the abundant metazoan fossils of the Ediacara assemblage (Jenkins, 1995; Gehling, 2000). These sands are also represented in part of the Officer Basin, and all were possibly sourced from the rising Musgrave Province.

- The Phanerozoic history of the basins is complex and beyond the scope of detailed discussion. Effects of the Petermann Range Orogeny continued into the Early Cambrian. The Musgrave Province shed coarse-grained arkosic and conglomeratic sediments to the south into the Officer Basin, to the north into the Amadeus Basin, and into two intra-montane pull-apart basins. In the Adelaide Geosyncline and eastern Gawler Craton, there was differential uplift on fault blocks and peneplanation, followed by marine transgression. Early Cambrian carbonate and then redbed deposition in the Flinders Ranges region was terminated by the $\sim 515-490 \mathrm{Ma}$ Delamerian Orogeny, but deposition continued in the Centralian Superbasin until the onset of the mid-Palaeozoic Alice Springs Orogeny.

\section{References}

Barovich, K.M. and Foden, J., 2000. A Neoproterozoic flood basalt province in southern-central Australia: geochemical and Nd isotope evidence from basin fill. Precambrian Research 100:213-234.

Calver, C.R., 1998. Isotope stratigraphy of the Neoproterozoic Togari Group, Tasmania. Australian Journal of Earth Sciences, 54:865-874.

Coats, R.P. and Preiss, W.V., 1980. Stratigraphic and geochronological reinterpretation of late Proterozoic glaciogenic sequences in the Kimberley region, Western Australia. Precambrian Research, 13:181-208.

Fanning, C.M. and Link, P., 2006. Constraints on the timing of the Sturtian glaciation from southern Australia; i.e. for the true Sturtian. Geological Society of America Abstracts with Programs 38 (7): 115. 
Gehling, J.G., 2000.Environmental interpretation and a sequence stratigraphic framework for the terminal Proterozoic Ediacara Member within the Rawnsley Quartzite. Precambrian Research 100:65-95.

Jenkins, R.J.F., 1995. The problems and potential of using animal fossils and trace fossils in terminal Proterozoic biostratigraphy. Precambrian Research, 73:51-70.

Maidment, D.W., Hand, M. and Williams, I.S., 2004. The Harts Range Metamorphic Complex - a Neoproterozoic to Cambrian metamorphosed rift sequence in the eastern Arunta region. Annual Geoscience Exploration Seminar 2004. Northern Territory Geological Survey Record 2004-001: 29-31.

Preiss, W.V., 2000. The Adelaide Geosyncline of South Australia and its significance in Neoproterozoic continental reconstruction. Precambrian Research 100:21-63.

Walter, M.R., Veevers, J.J., Calver, C.R., Grey, K., 1995. Neoproterozoic stratigraphy of the Centralian Superbasin, Australia. Precambrian Research, 73:173-195.

Wingate, M.T.D., Campbell, I.H., Compston, W. and Gibson, G.M., 1998. Ion-probe U-Pb ages for Neoproterozoic basaltic magmatism in south-central Australia and implications for the break-up of Rodinia. Precambrian Research, 87:135-159. 
NOTES: 


\section{Facies-dependant $\delta^{13} \mathrm{C}$ variation from an interglacial platform margin, South Australia: Evidence for ocean stagnation during the Cryogenian?}

Jonathan A. Giddings

School of Earth Sciences,

The University of Melbourne, Victoria 3010

jagiddings@gmail.com

\section{Biography:}

Jonathan Giddings recently completed his $\mathrm{PhD}$ at the University of Melbourne (2008). He studied the sedimentology, stratigraphy and C-isotope geochemistry of the Cryogenian interglacial succession in the northern Adelaide Geosyncline, South Australia.

\subsection{Introduction}

Severe global ice ages that occurred during the Proterozoic (snowball Earth events) have been widely accepted as the coldest intervals in Earth history (Kirschvink, 1992; Hoffman et al., 1998a, b), yet their origin is still strongly debated. With improved radiometric age constraints, at least three major ice ages can now be recognised within the Neoproterozoic: (1) An interval of Sturtian age between $\sim 723$ and 658 Ma (Brasier et al., 2000a; Lund et al., 2003; Fanning and Link, 2004; Fanning and Link, 2006); (2) An event of Marinoan age ending at $635 \mathrm{Ma}$ (Hoffmann et al., 2004, Condon et al., 2005), and; (3) A less severe, late-Marinoan (Ediacaran) event referred to as the 'Gaskiers' glaciation at around $580 \mathrm{Ma}$ (Bowring et al., 2003). An earlier period of global glaciation occurred during the Palaeoproterozoic between 2400 and $1800 \mathrm{Ma}$, with the major Makganyene (or Huronian) event occurring at around $2400 \mathrm{Ma}$ (Williams and Schmidt, 1997; Kirschvink et al., 2000; Polteau et al., 2006) and a later event occurring in Australia at $1800 \mathrm{Ma}$ (Williams, 2005).

Both the Neoproterozoic and Palaeoproterozoic glaciations coincide with large fluctuations in the $\delta^{13} \mathrm{C}$ record of marine carbonates that are unparalleled during Phanerozoic time (Walter et al., 2000) (Fig. 8.1). This close association between large-scale $\delta^{13} \mathrm{C}$ variation and climate during the Proterozoic strongly supports the commonly held perception that the carbon cycle plays a major role in regulating global climate. In addition, the Neoproterozoic isotope record has generally been interpreted to reflect secular variation in the $\delta^{13} \mathrm{C}$ composition of seawater resulting from major perturbations in the biogeochemical carbon cycle (Hoffman et al., 1998b; Knoll, 2000; Ripperdan, 1994, 2001; Hoffman and Schrag, 2002; Rothman et al., 2003; Halverson et al., 2005). This has lead to its popular use as a tool for intra- and interbasinal stratigraphic correlation in an effort to improve relative age constraints on Neoproterozoic successions, which are plagued by a lack of biostratigraphic control and a limited number of radiometric dates (eg. Knoll et al., 1986; Kaufman and Knoll, 1995; Corsetti et al., 2000; Walter et al., 2000; Brasier and Shields, 2000; Halverson et al., 2002, 2005; Le Guerroué et al., 2006a; Misi et al., 2007; Zhou and Xiao, 2007).

This presentation will show how the current interpretation that the Neoproterozoic marine $\delta^{13} C_{\text {carb }}$ record is controlled solely by global or secular variation in the composition of the ocean may be incorrect, and that spatial variation in ocean chemistry may explain much of the observed variation. Recent research shows ${ }^{13} \mathrm{C}$-enrichment in shallow-water carbonates relative to their deeper water equivalents, indicating the possible existence of a high shallow to deep-water $\delta^{13} \mathrm{C}$ gradient (James et al., 2001; Ross et al., 2001; Xiao et al., 2004; Shen et al., 2005, Hurtgen et al., 2006; Zhou et al., 2004; Hoffman et al., 2007; Jiang et al., 2007). These findings could have significant implications for our understanding of the Neoproterozoic carbon cycle, the causes of global climatic events and the use of chemostratigraphy as a high-resolution chronostratigraphic correlation technique.

In order to test for spatial $\delta^{13} \mathrm{C}$ variation in Neoproterozoic seawater, we carried out a detailed stable isotope analysis of the Cryogenian Umberatana Group in the Adelaide Geosyncline, South Australia (Fig. 8.2). The study involved applying a chronostratigraphic approach to the succession with the aim of testing for facies-dependant $\delta^{13} \mathrm{C}$ variation during the interglacial period following the lower 
Cryogenian (Sturtian) glaciation. Sedimentary and stratigraphic evidence from a previous study indicates the progradation of an extensive reef margin (Balcanoona Formation) during midinterglacial times, culminating in a steep shelf break with high relief (at least $1 \mathrm{~km}$ ) (Giddings et al., in press). The reef margin, previously referred to as a "submarine escarpment" (Coats and Blissett, 1971; Preiss, 1987), is well exposed near Oodnaminta Hut, where a thick sequence of Balcanoona Formation extends northwards and is truncated abruptly by fine siliciclastic and carbonate sediments that filled the basin to the north and onlap the Oodnaminta reef. Isotopic data from this shelf-basin transition show strong evidence for spatial $\delta^{13} \mathrm{C}$ variation, the possible causes of which will be discussed along with their potential influence on climate during this important period in Earth history.

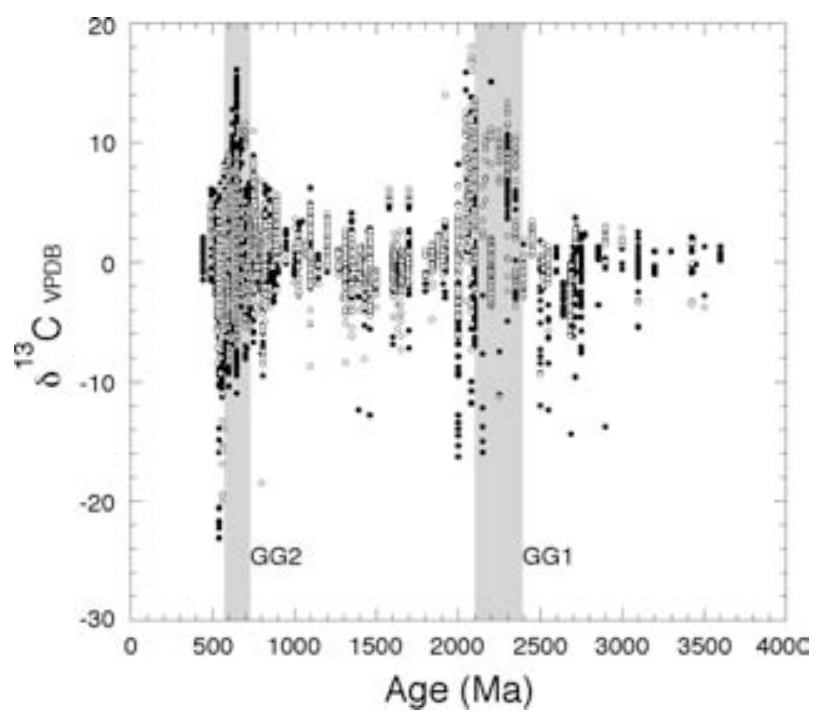

Fig. 8.1. Global compilation of $\delta^{13} \mathrm{C}$ data from marine carbonates through Earth history (Shields and Veizer, 2002), showing the temporal relationship between large magnitude $\delta^{13} \mathrm{C}$ variations and the Palaeoproterozoic (GG1) and Neoproterozoic (GG2) periods of global glaciation. Filled circles represent calcite and open circles represent dolomite (Giddings and Wallace, in press).

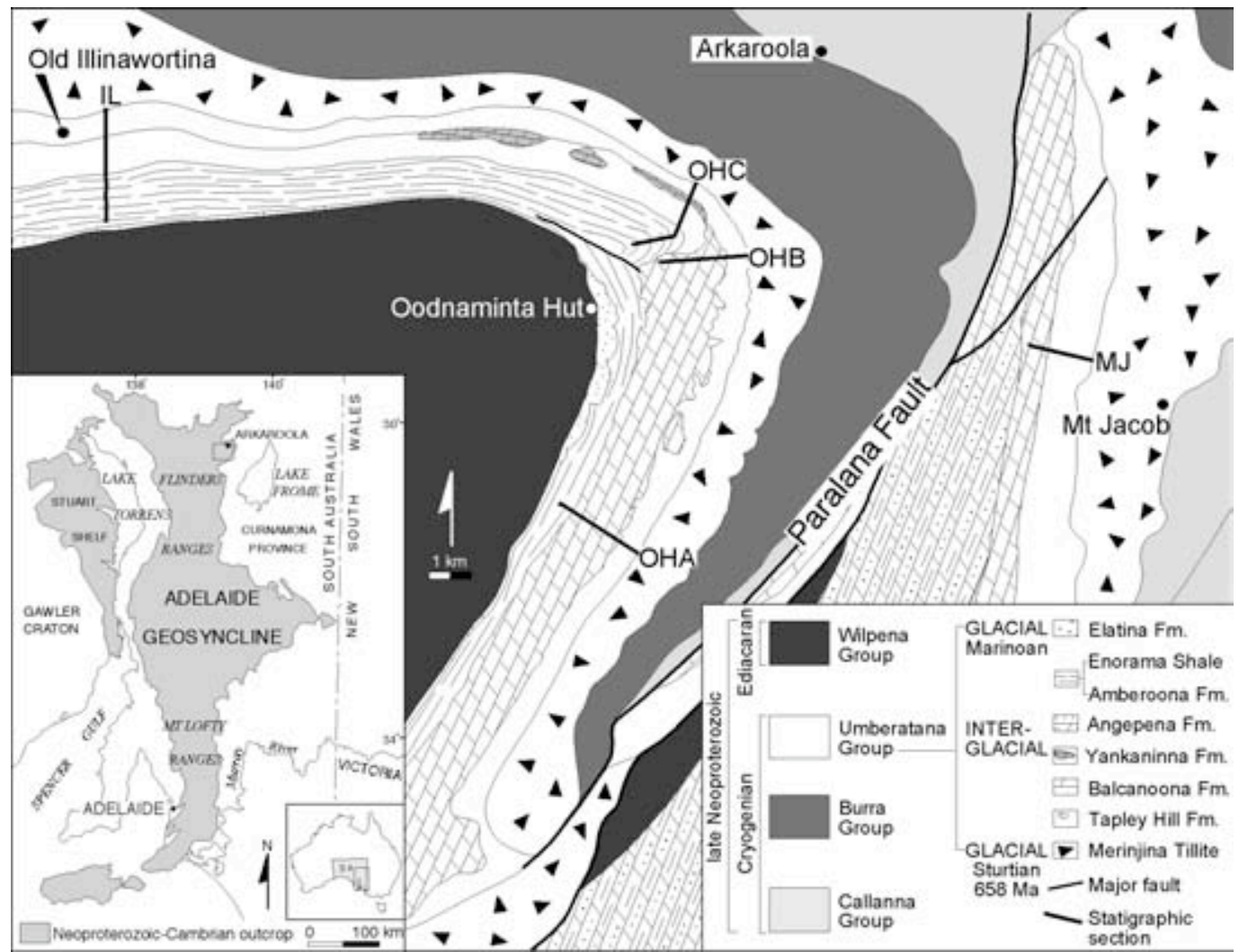

Fig. 8.2. Location of the Adelaide Geosyncline and generalised geological map of the region south of Arkaroola, northern Flinders Ranges. Section localities are also shown (Mt. Jacob - MJ, Oodnaminta Hut - OHA-C, Illinawortina - IL). Modified from Coats (1973). 


\subsection{Summary of chronostratigraphic relationships}

A detailed stratigraphic and sedimentological analysis of the Umberatana Group was undertaken in conjunction with the stable isotope study. The main purpose of this was to construct a chronostratigraphic and palaeo-environmental framework for the sediments. Stratigraphic sections were measured from a number of localities (Fig. 8.2) and the succession was subdivided into informal stratigraphic units that were used as chronostratigraphic markers for correlation between sections (Fig. 8.3, 8.4). Detailed chronostratigraphic correlations are displayed in figures 8.3 and 8.4. Of particular interest for this study are the correlations between platform (back-reef, reef-margin), slope and basinal sediments of the Balcanoona, Tapley Hill and Yankaninna Formations (Fig. 8.4).

Reef progradation in the Oodnaminta Hut region was contemporaneous with deposition of the upper section of the Tapley Hill Formation (transitional shale unit). Recognisable reef progradation surfaces in the Balcanoona Formation that are representative of previous margins allow horizons to be traced from the back-reef facies to the foot of the margin where correlative deep-water sediments onlap. Correlation into the base-of-slope sediments is imprecise due to the presence of megabreccia deposits that have eroded into synchronous deep-water sediments. Approximately $\sim 50-100 \mathrm{~m}$ of sediment is estimated to have been removed by the final margin collapse event (basinal megabreccia) and only a range of isotope values can be determined for this part of Oodnaminta Hut section $\mathrm{C}$ - those immediately above and below the basinal megabreccia. High-resolution correlation can be achieved with the deep, basinal sediments of the Tapley Hill Formation in the Illinawortina section, located 14 $\mathrm{km}$ from the platform margin. Here allochthonous reef blocks equivalent to those in the basinal megabreccia are present in deep-water host shales at the same stratigraphic level as those near Oodnaminta Hut. This horizon can be traced between these two sections in the field and is visible on aerial photographs. There is no evidence for significant erosion at this stratigraphic level in the Illinawortina section, allowing high-resolution correlation with the reef carbonates.

This scenario allows for two isotopic tests to be carried out for detection of a $\delta^{13} \mathrm{C}$-facies relationship: (1) Comparison of correlative shallow and deep-water sediments and: (2) Comparison of allochthonous shallow-water reef-framework blocks directly with their deep-water host shales.

\subsection{Stable isotope results}

The $\delta^{13} \mathrm{C}$ values for all five sections (Mt. Jacob, Oodnaminta Hut A-C, and Illinawortina) are shown in isotopic profiles that accompany the stratigraphic sections in figures 8.3 and 8.4. Average allochthonous block values and average values for key facies are summarised in figure 8.5.

All sections begin with a negative $\delta^{13} \mathrm{C}$ excursion at the base of the Tapley Hill Formation in the cap carbonate (Oodnaminta Hut section A unsampled). In the Mt. Jacob section, values in the cap carbonate range between $-3.6 \%$ and $-0.3 \%$ (Fig. 8.3), in the Oodnaminta Hut sections between $-4.1 \%$ o and $-5.5 \%$, and in the Illinawortina section between $-3.7 \%$ and $-6.7 \%$ (Fig. 8.4). Values in the Mt. Jacob and Oodnaminta Hut sections increase through the Tindelpina Shale Member and culminate in a peak within the siltstone unit of 3-6\%o. Above this point values decrease gradually over the next 200 $\mathrm{m}$ of section to between $-5 \%$ and $-8.5 \%$, typically reaching the lowest values above the quartzsandstone unit. These positive and negative excursions are not present in the Illinawortina section, which shows a general heavying trend through the lower Tapley Hill Formation from the top of the cap carbonate. In the Mt. Jacob section, values rise progressively from the top of the quartz-sandstone unit through the upper transitional shale unit of the Tapley Hill Formation, to values of $0-1.7 \%$. Values in the overlying Balcanoona Formation range between 3\%o and 4\%o. In Oodnaminta Hut section $\mathrm{B}$, this transition to high $\delta^{13} \mathrm{C}$ values in the Balcanoona Formation is very sharp across the erosional contact with the basal dolomite-megabreccia facies. Values within the reef complex range between $3 \%$ and $7 \%$, and in the very shallow-water back-reef facies reach a peak of $8.2 \%$. 
Deep-water calcareous shales deposited during reef-progradation have values ranging between $-2.7 \%$ o and $-0.3 \%$ at Illinawortina. During late-stage reef growth, following deposition of basinal megabreccia, the deep-water calcareous shales from the Illinawortina section and Oodnaminta Hut section $\mathrm{C}$ have a combined average value of $0.8 \%$. Limestone allochthonous blocks embedded within these sediments have an average $\delta^{13} \mathrm{C}$ value of $7.3 \%$, whilst dolomite blocks collected from the underlying megabreccia unit have an average $\delta^{13} \mathrm{C}$ value of $4.9 \%$ (total block ave. $=6.6 \%$ ).

Throughout the post-reef slope and basinal sediments, values in both sections are generally positive, with the most enriched compositions in both sections preserved in the laminated-limestone units (7.510.3\%o) (Fig. 8.4). However, some of the intervening shale units have more depleted compositions (down to $-6.7 \%$ ). Values in both sections remain positive until a negative excursion appears at the base of the Enorama Shale, in which values drop to as low as $-6.8 \%$.

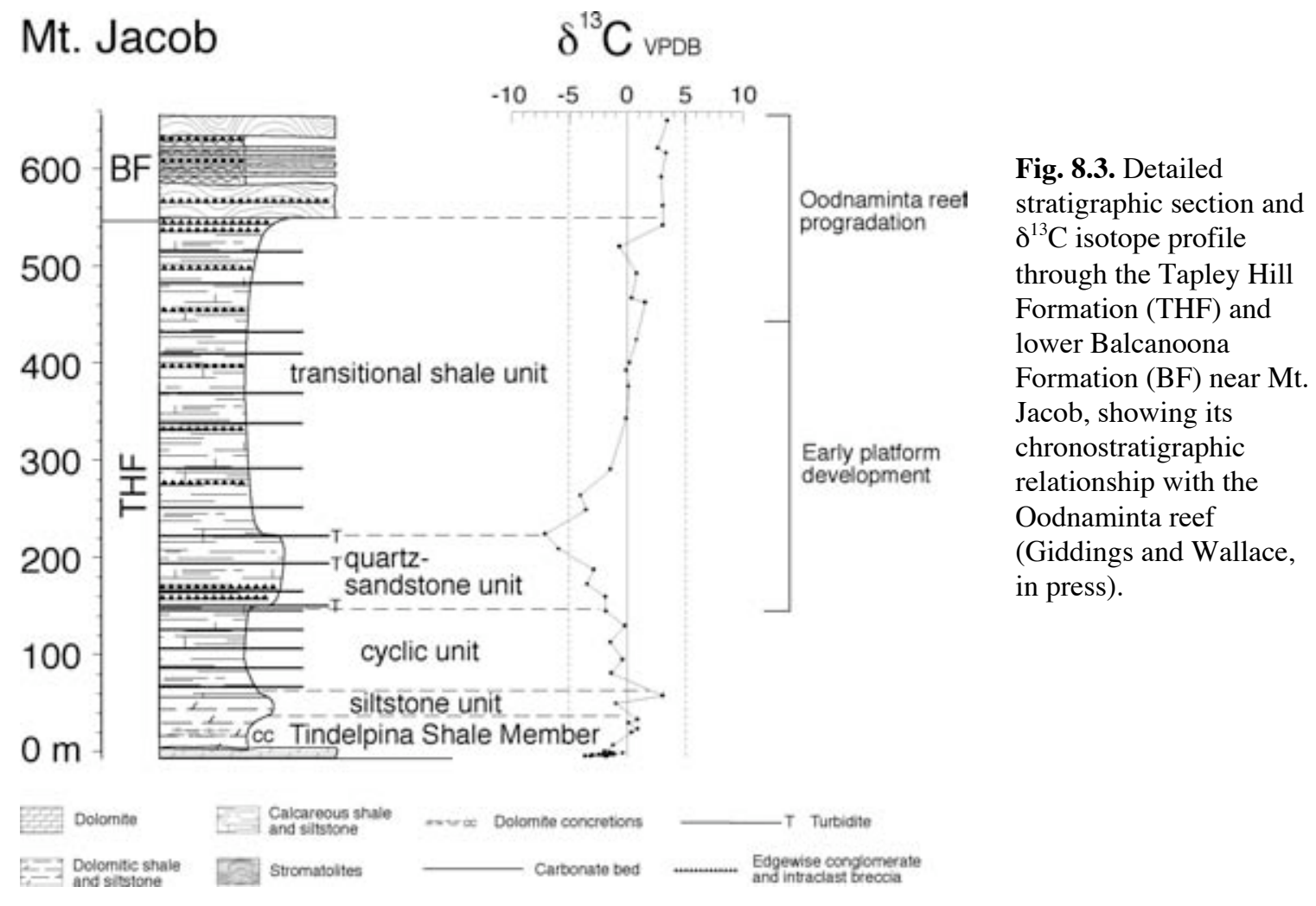

Fig. 8.4 (next page). Detailed stratigraphic sections from back-reef (Oodnaminta Hut section A), reef-margin (Oodnaminta Hut section B), slope (Oodnaminta Hut section C) and slope-basin (Illinaworina) localities, accompanied by $\delta^{13} \mathrm{C}$ profiles. Dashed lines show chronostratigraphic correlations. THF - Tapley Hill Formation, BF - Balcanoona Formation, YF - Yankaninna Formation, AF - Amberoona Formation, ES - Enorama Shale (Giddings and Wallace, in press). 


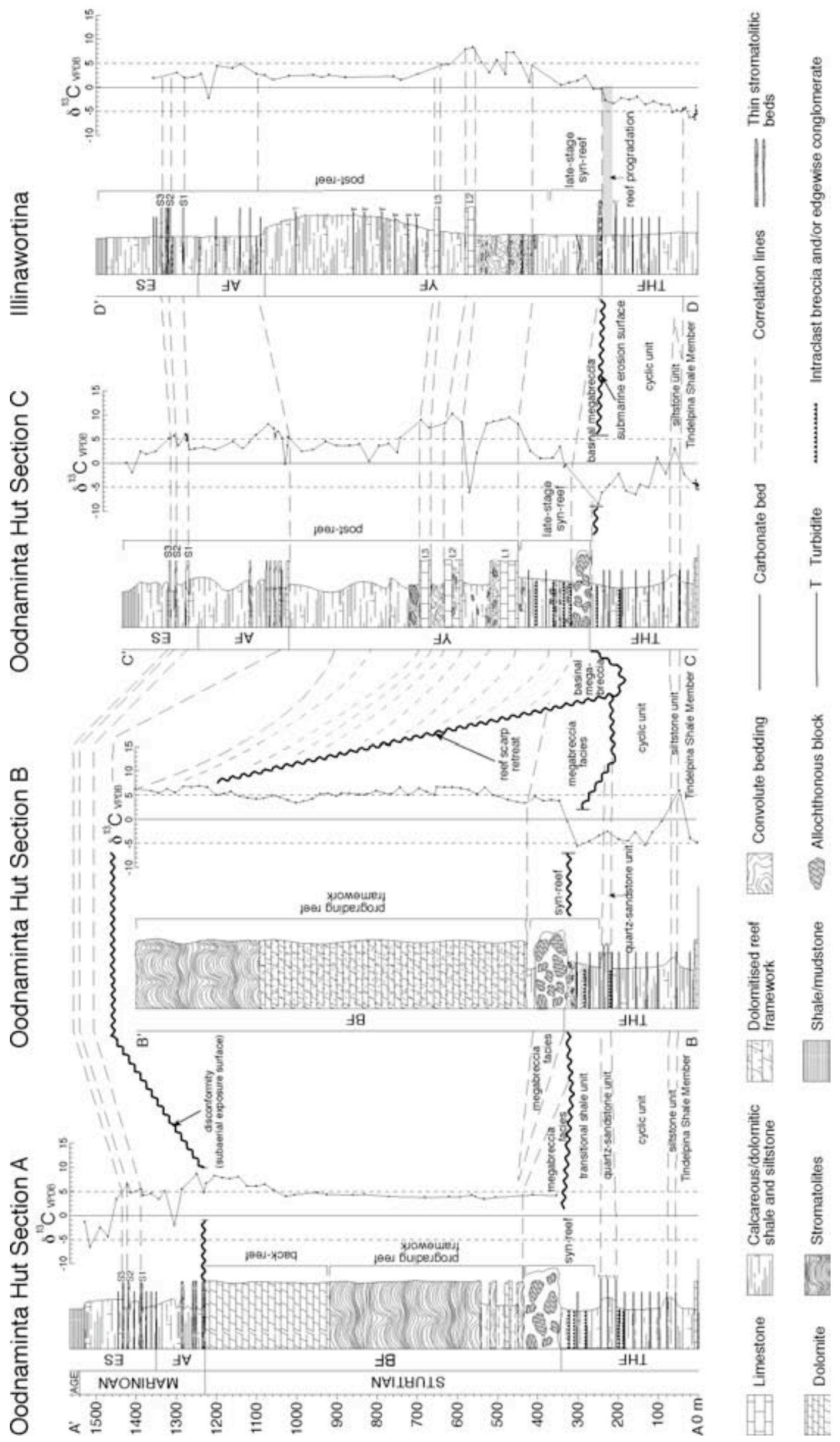




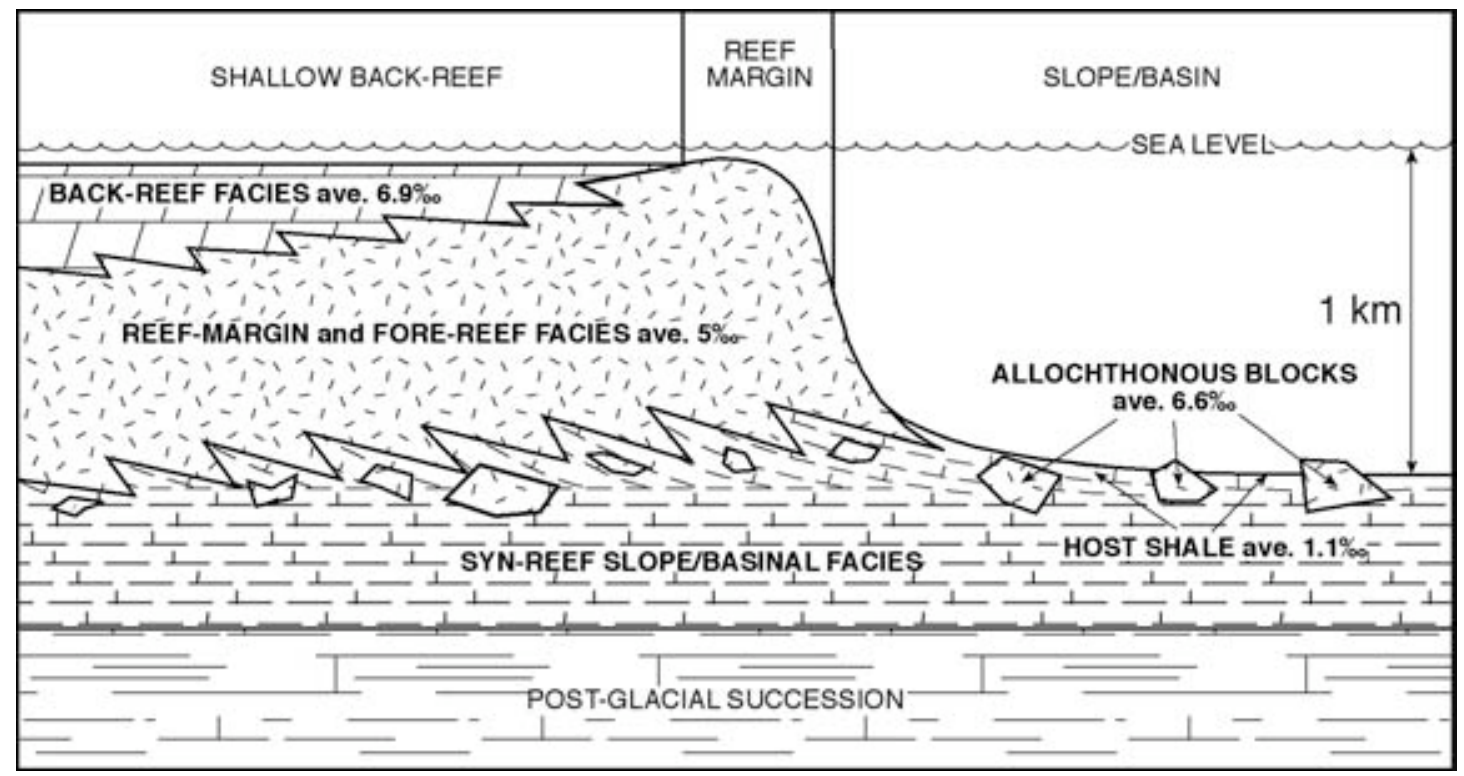

Fig. 8.5. Schematic stratigraphic diagram showing the relationship between the reef, slope and basinal facies. Also shown are average $\delta^{13} \mathrm{C}$ values for the different facies and those of allochthonous blocks derived from the platform margin (Giddings and Wallace, in press).

\subsection{Discussion and Conclusions}

Rapid lateral facies changes occur along transect from reef margin to basinal environments of the Umberatana Group in the northern Adelaide Geosyncline. This scenario provides a rare opportunity to compare $\delta^{13} \mathrm{C}$ values of synchronously deposited shallow and deep-water sediments deposited during the Cryogenian, between the Sturtian and Marinoan-aged glacial events. Such comparisons reveal a $\delta^{13} \mathrm{C}$ depth gradient of 8-11\%o between surface and deep waters during this time. The high level of facies-dependant $\delta^{13} \mathrm{C}$ variation observed has significant implications for the use of carbon isotopes for stratigraphic correlation because synchronous shallow and deep-water sediments may have significantly different carbon isotope compositions. This chemical heterogeneity in the Neoproterozoic Ocean has the potential to obscure a record of secular change in the composition of the whole ocean, making high-resolution inter- and intrabasinal chemostratigraphic correlation difficult.

We suggest that the observed $\delta^{13} \mathrm{C}$-facies relationship is most consistent with a model of long-lived ocean stratification/stagnation in the Neoproterozoic (Fig. 8.6). While it is impossible to completely rule out diagenetic influences on our deep-water $\delta^{13} \mathrm{C}$ data, the stratigraphic consistency of the data on a basin-wide scale suggests significant diagenetic influence is unlikely. The stratigraphic $\delta^{13} \mathrm{C}$ trends observed in the Tapley Hill Formation in this study are the same in the majority of our sections and mimic those of a previous stable isotope study of the same succession near Blinman, $100 \mathrm{~km}$ from our study area (McKirdy et al., 2001). Assuming a dominantly primary $\delta^{13} \mathrm{C}$ signal, we suggest that the observed $\delta^{13} \mathrm{C}$ depth gradient is a direct result of prolonged oceanic stratification during which time anoxic deep waters developed beneath well-oxygenated shallow waters, with very little vertical mixing between the two reservoirs (Fig. 8.6). A $\delta^{13} \mathrm{C}$ depth gradient in the order of 8-11\%o would be a predictable consequence of these conditions due to the effect of the 'biological pump'. Photosynthetic production of organic matter in the photic zone extracts ${ }^{12} \mathrm{C}$ from surface waters and recycles it back into the deep ocean in the form of dissolved inorganic carbon (DIC) as organic particles sink through the water column and are oxidised. In the well-mixed modern ocean, this process leads to a $\delta^{13} \mathrm{C}$ depth gradient of $\sim 1-2 \%$ with deep waters depleted in ${ }^{13} \mathrm{C}$ relative to surface waters (Kroopnick, 1985; Hotinski et al., 2004). After prolonged ocean stratification and continued biological pumping, deep waters would become progressively more depleted and surface waters more enriched (Weissert, 1979; 
Knoll et al., 1996), leading to isotopically heavy shallow-water and isotopically light deep-water carbonates.

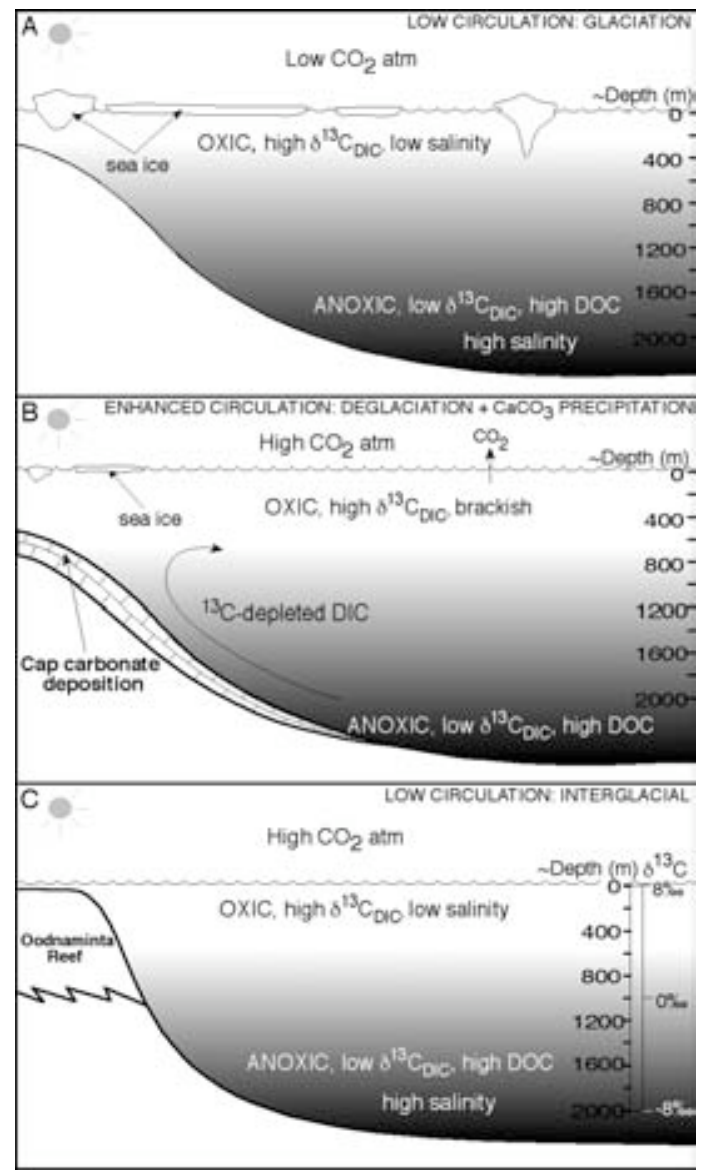

Fig. 8.6. Schematic diagram of the stratified Neoproterozoic Ocean.

(A) In the intensely stratified syn-glacial ocean, saline deep waters become ${ }^{13} \mathrm{C}$-depleted and anoxic, whilst surface waters become ${ }^{13} \mathrm{C}$-enriched and oxic due to biological pumping.

(B) Deglaciation results from invigorated circulation with a degree of deep-ocean ventilation sufficient to supply enough $\mathrm{CO}_{2}$ to the surfaceocean and atmosphere to cause global warming, whilst maintaining a stratified state in the longterm. Upwelling of ${ }^{13} \mathrm{C}$-depleted alkalinity facilitates cap carbonate precipitation.

(C) Growth of the Oodnaminta Reef during the interglacial period occurs in a poorly mixed, stratified ocean and reef carbonates inherit the heavy isotopic signature of the surface ocean $(<\sim 800 \mathrm{~m})$, while slope and basinal sediments reflect the lighter isotopic composition of the deep-ocean reservoir $(>\sim 1000 \mathrm{~m})$. DIC - dissolved inorganic carbon, DOC - dissolved organic carbon (Giddings and Wallace, in press).

It is possible that oceanic stratification may have persisted for much of the late Neoproterozoic (and likely early-Cambrian, $\sim 750-500 \mathrm{Ma}$ ) and possibly throughout the Palaeoproterozoic glacial periods (2400 Ma, $1800 \mathrm{Ma}$ ). Such stratification may explain the large magnitude of $\delta^{13} \mathrm{C}$ variation observed in Neoproterozoic sediments and removes the need to invoke purely temporal changes in whole-ocean chemistry. The climatic implications of persistent stratification may also be profound (Fig. 8.6). Accumulation of large amounts of $\Sigma \mathrm{CO}_{2}$ in the deep ocean during stratification and its subsequent rapid release during re-invigorated mixing, could explain not only the occurrence of severe glaciation but also the rapid deglaciations that characterise these events (Grotzinger and Knoll, 1995; Knoll et al., 1996). Re-invigorated oceanic mixing during deglaciation could also have resulted in the upwelling of large amounts of carbonate alkalinity, leading to carbonate over-saturation in the upper ocean and initiating the precipitation of globally extensive cap carbonates.

\subsection{References}

Bowring S, Myrow P, Landing E, Ramezani J, Grotzinger J (2003) Geochronological contraints on terminal Neoproterozoic events and the rise of metazoans. Geophysical Research Abstracts 5, 13219.

Brasier M, McCarron G, Tucker R, Leather J, Allen P, Shields G (2000) New U-Pb zircon dates for the Neoproterozoic Ghubrah glaciation and for the top of the Huqf Supergroup, Oman. Geology 28, 175-178.

Coats, R.P. and Blissett, A.H., (1971). Regional and economic geology of the Mount Painter Province, Geological Survey of South Australia Bulletin, 43. Department of Mines, Geological Survey of South Australia, Adelaide.

Coats RP (1973) COPLEY map sheet, Geological Atlas of South Australia, 1:250 000 series. In. (Geological Survey of South Australia: Adelaide).

Condon D, Zhu MY, Bowring S, Wang W, Yang AH, Jin YG (2005) U-Pb ages from the Neoproterozoic Doushantuo Formation, China. Science 308, 95-98.

Corsetti FA, Awramik SM, Pierce D, Kaufman AJ (2000) Using chemostratigraphy to correlate and calibrate unconformities in Neoproterozoic strata from the southern Great Basin of the United States. International Geology 
Review 42, 516-533.

Fanning CM, Link PK (2004) U-Pb SHRIMP ages of Neoproterozoic (Sturtian) glaciogenic Pocatello Formation, southeastern Idaho. Geology 32, 881-884.

Fanning CM, Link PK (2006) Constraints on the timing of the Sturtian glaciation from Southern Australia: i.e. for the true Sturtian. In '2006 Philadelphia Annual Meeting (22-25 October 2006)'. Philadelphia, Pennsylvania pp. paper \# 42-6

Giddings, J.A. and Wallace, M.W. Facies-dependent $\delta^{13} \mathrm{C}$ variation from a Cryogenian platform margin, South Australia: Evidence for stratified Neoproterozoic oceans? Palaeogeography, Palaeoclimatology, Palaeoecology, in press.

Giddings, J.A., Wallace, M.W. and Woon, E.M.S. Interglacial carbonates of the Cryogenian Umberatana Group, northern Flinders Ranges, South Australia. Australian Journal of Earth Sciences, in press.

Grotzinger JP, Knoll AH (1995) Anomalous carbonate precipitates; is the Precambrian the key to the Permian? Palaios 10, 578-596.

Halverson GP, Hoffman PF, Schrag DP, Kaufman AJ (2002) A major perturbation of the carbon cycle before the Ghaub glaciation (Neoproterozoic) in Namibia: Prelude to snowball Earth? Geochemistry Geophysics Geosystems 3.

Halverson GP, Hoffman PF, Schrag DP, Maloof AC, Rice AHC (2005) Toward a Neoproterozoic composite carbonisotope record. GSA Bulletin 117, 1181-1207.

Hoffman PF, Halverson GP, Domack EW, Husson JM, Higgins JA, Schrag DP (2007) Are basal Ediacaran (635 Ma) postglacial "cap dolostones" diachronous? Earth and Planetary Science Letters 258, 113-131.

Hoffman PF, Kaufman AJ, Halverson GP (1998) Comings and goings of global glaciations on a Neoproterozoic tropical platform in Namibia. GSA Today 8, 1-9.

Hoffman PF, Kaufman AJ, Halverson GP, Schrag DP (1998) A Neoproterozoic Snowball Earth. Science 281, $1342-1346$.

Hoffman PF, Schrag DP (2002) The snowball Earth hypothesis: testing the limits of global change. Terra Nova 14, 129155.

Hoffmann KH, Condon DJ, Bowring SA, Crowley JL (2004) U-Pb zircon date from the Neoproterozoic Ghaub Formation, Namibia: Constraints on Marinoan glaciation. Geology 32, 817-820.

Hotinski RM, Kump LR, Arthur MA (2004) The effectiveness of the Paleoproterozoic biological pump: A $\delta^{13} \mathrm{C}$ gradient from platform carbonates of the Pethei Group (Great Slave Lake Supergroup, NWT). GSA Bulletin 116, 539-554.

Hurtgen MT, Halverson GP, Arthur MA, Hoffman PF (2006) Sulfur cycling in the aftermath of a 635-Ma snowball glaciation: Evidence for a syn-glacial sulfidic deep ocean. Earth and Planetary Science Letters 245.

James NP, Narbonne GM, Kyser TK (2001) Late Neoproterozoic cap carbonates: Mackenzie Mountains, northwestern Canada: precipitation and global glacial meltdown. Canadian Journal of Earth Sciences 38, 1229-1262.

Jiang G, Kaufman AJ, Christie-Blick N, Zhang S, Wu H (2007) Carbon isotope variability across the Ediacaran Yangtze platform in South China: Implications for a large surface-to-deep ocean $\delta^{13} \mathrm{C}$ gradient. Earth and Planetary Science Letters 261, 303-320.

Kaufman AJ, Knoll AH (1995) Neoproterozoic variations in the C-isotopic composition of seawater; stratigraphic and biogeochemical implications. Precambrian Research 73, 27-49.

Kirschvink JL (1992) Late Proterozoic Low-Latitude Global Glaciation: the Snowball Earth. In 'The Proterozoic biosphere; a multidisciplinary study'. (Eds JW Schopf and C Klein). (Univ. Cambridge, Cambridge, United Kingdom)

Kirschvink JL, Gaidos EJ, Bertani LE, Beukes NJ, Gutzmer J, Maepa LN, Steinberger RE (2000) Paleoproterozoic snowball Earth; extreme climatic and geochemical global change and its biological consequences. Proceedings of the National Academy of Sciences of the United States of America 97, 1400-1405.

Knoll AH (2000) Learning to tell Neoproterozoic time. Precambrian Research 100, 3-20.

Knoll AH, Bambach RK, Canfield DE, Grotzinger J (1996) Comparative Earth history and late Permian mass extinction. Science 273, 452-457.

Knoll AH, Hayes JM, Kaufman AJ, Swett K, Lambert IB (1986) Secular variation in carbon isotope ratios from Upper Proterozoic successions of Svalbard and East Greenland. Nature 321, 832-838.

Kroopnick PM (1985) The distribution of $\delta^{13} \mathrm{C}$ of $\Sigma \mathrm{CO}_{2}$ in the world oceans. Deep-Sea Research. Part A: Oceanographic Research Papers 32, 57-84.

Le Guerroue E, Allen PA, Cozzi A (2006) Chemostratigraphic and sedimentological framework of the largest negative carbon isotopic excursion in Earth history: The Neoproterozoic Shuram Formation (Nafun Group, Oman). Precambrian Research 146, 68-92.

Lund K, Aleinikoff JN, Evans KV, Fanning CM (2003) SHRIMP U-Pb geochronology of Neoproterozoic Windermere Supergroup, central Idaho: Implications for rifting of western Laurentia and synchroneity of Sturtian glacial deposits. Geological Society of America Bulletin 115, 349-372.

McKirdy DM, Burgess JM, Lemon NM, Yu XK, Cooper AM, Gostin VA, Jenkins RJF, Both RA (2001) A chemostratigraphic overview of the late Cryogenian interglacial sequence in the Adelaide Fold-Thrust Belt, South Australia. Precambrian Research 106, 149-186.

Misi A, Kaufman AJ, et al. (2007) Chemostratigraphic correlation of Neoproterozoic successions in South America. Chemical Geology 237, 143-167.

Polteau S, Moore JM, Tsikos H (2006) The geology and geochemistry of the Palaeoproterozoic Makganyene diamictite. Precambrian Research 148, 257-274.

Preiss, W.V., (1987). The Adelaide Geosyncline - late Proterozoic stratigraphy, sedimentation, palaeontology and 
tectonics. Geological Survey of South Australia Bulletin, 53. Department of Mines, Geological Survey of South Australia, Adelaide.

Ripperdan RL (1994) Global variations in carbon isotope composition during the latest Neoproterozoic and earliest Cambrian. Annual Review of Earth and Planetary Sciences 22, 385-417.

Ripperdan RL (2001) Stratigraphic variation in marine carbonate carbon isotope ratios. Reviews in Mineralogy and Geochemistry 43, 637-662.

Ross GM, Rowe C, Augereau C (2001) Stable Isotope Stratification of Neoproterozoic Seawater in a Post-Snowball Earth: Evidence From Deepwater Rocks of Western Canada. In 'American Geophysical Union, Fall Meeting'. (American Geophysical Union)

Rothman DH, Hayes JM, Summons RE (2003) Dynamics of the Neoproterozoic carbon cycle. Proceedings of the National Academy of Sciences of the United States of America 100, 8124-8129.

Shen Y, Zhang TG, Chu XL (2005) C-isotopic stratification in a Neoproterozoic postglacial ocean. Precambrian Research 137, 243-251.

Shields G, Veizer J (2002) Precambrian marine carbonate isotope database: Version 1.1. Geochemistry, Geophysics, Geosystems - G (super 3) 3, 10.1029/2001GC000266.

Walter MR, Veevers JJ, Calver CR, Gorjan P, Hill AC (2000) Dating the 840-544 Ma Neoproterozoic interval by isotopes of strontium, carbon, and sulfur in seawater, and some interpretative models. Precambrian Research 100, 371-433.

Weissert H, McKenzie J, Hochuli P (1979) Cyclic anoxic events in the Early Cretaceous Tethys Ocean. Geology 7, 147151.

Williams GE (2005) Subglacial meltwater channels and glaciofluvial deposits in the Kimberley Basin, Western Australia: $1.8 \mathrm{Ga}$ low-latitude glaciation coeval with continental assembly. Journal of the Geological Society 162, 111-124.

Williams GE, Schmidt PW (1997) Paleomagnetism of the Paleoproterozoic Gowganda and Lorrain formations, Ontario; low paleolatitude for Huronian glaciation. Earth and Planetary Science Letters 153, 157-169.

Xiao SH, Bao HM, Wang HF, Kaufman AJ, Zhou CM, Li GX, Yuan XL, Ling HF (2004) The Neoproterozoic Quruqtagh Group in eastern Chinese Tianshan: evidence for a post-Marinoan glaciation. Precambrian Research 130, 1-26.

Zhou CM, Tucker R, Xiao SH, Peng ZX, Yuan XL, Chen Z (2004) New constraints on the ages of Neoproterozoic glaciations in south China. Geology 32, 437-440.

Zhou C, Xiao S (2007) Ediacaran $\delta^{13} \mathrm{C}$ chemostratigraphy of South China. Chemical Geology 237, 89-108. 
NOTES: 


\section{Tasmanian Neoproterozoic glacial deposits and their age constraints}

\section{Clive R. Calver}

Mineral Resources Tasmania, PO Box 56, Rosny Park, Tasmania 7054

Email: ccalver@mrt.tas.gov.au

\section{Biography:}

Clive Calver graduated with a B.Sc. (Hons) in geology from the University of Tasmania in 1977. Since then he has worked for Mineral Resources Tasmania and predecessor organisations, much of the time mapping Tasmania's Proterozoic rocks. He undertook a $\mathrm{PhD}$ on Ediacaran isotope stratigraphy at Macquarie University in the early 1990's.

On King Island and in north-west Tasmania, three distinct late Neoproterozoic diamictite units of probable glacial origin can be correlated with the Sturtian, Elatina ('Marinoan') and Gaskiers glaciations. Rift volcanics are interbedded with the Tasmanian diamictites, allowing more scope for dating than in most mainland Australian successions and thereby contributing to resolving the vexed questions of ages and synchroneity of Neoproterozoic glaciations, and the age of the base of the Ediacaran System in Australia.

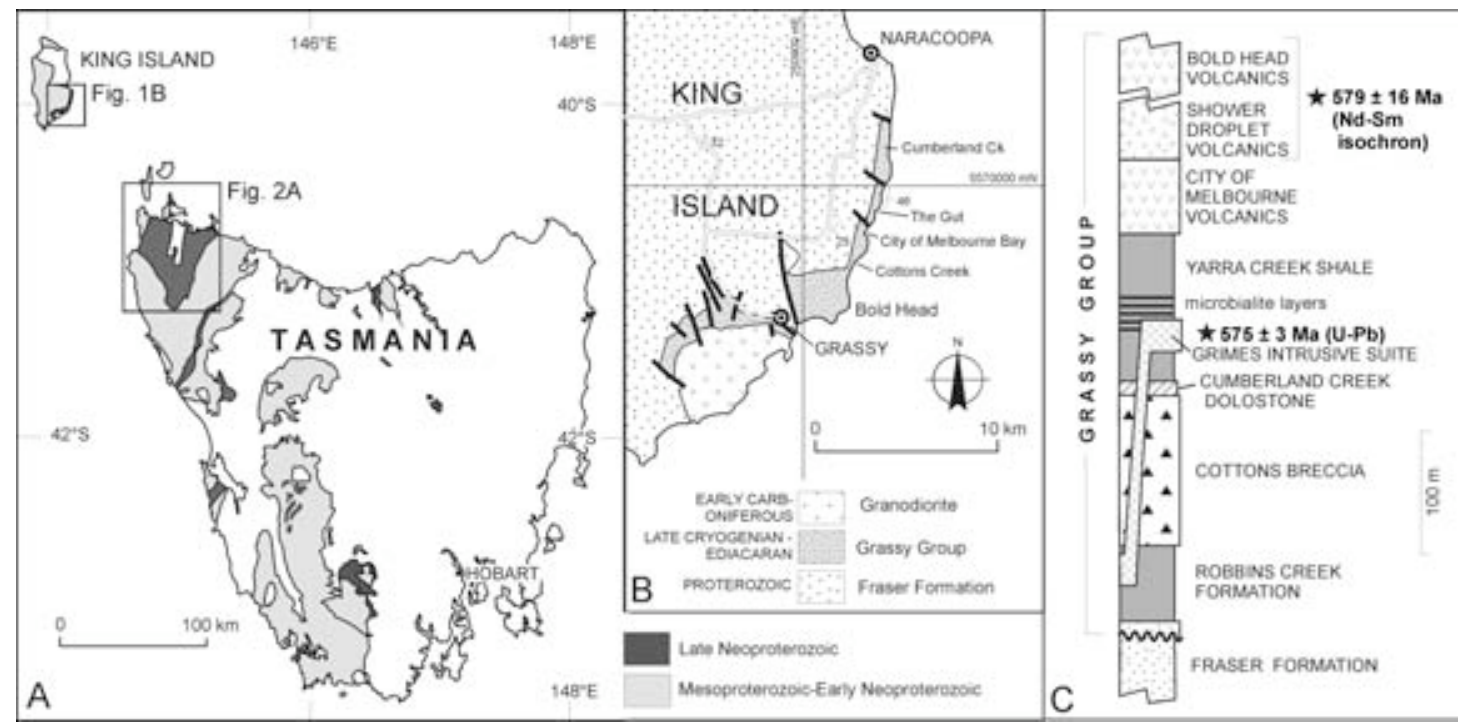

Fig. 9.1. A: Distribution of Proterozoic rocks in Tasmania; B: Simplified geological map of southeast King Island; C: generalised stratigraphic section through Grassy Group in Bold Head-Cumberland Creek area.

On King Island (Fig. 9.1), mapping over the 2007-2008 summer has clarified many of the relationships of the glacigene and associated units (Calver, in prep.). An Elatina Formation correlative, the Cottons Breccia, is found near the base of the Grassy Group. The Grassy Group unconformably overlies a thick mudstone -siltstone sequence, the Fraser Formation, loosely constrained between 1400 - 750 Ma (Direen \& Jago, 2008; Calver, in prep.). The basal formation of the Grassy Group (Robbins Creek Formation: Calver, in prep; Fig. 9.1) comprises basal conglomerate, laminated siltstone-shale, and minor mafic lavas. The overlying Cottons Breccia has a variable thickness $(40-150 \mathrm{~m})$ partly owing to erosional incision into the Robbins Creek Formation. Most of the Cottons Breccia is massive, open-framework diamictite with a grey, carbonate-rich matrix and clasts mostly of carbonates, with subordinate metasiltstone, shale, chert, and basalt. Towards the top of the Cottons Breccia is a lens of mafic-volcaniclastic sandstone, succeeded by an uppermost unit of weakly stratified diamictite with minor sandstone interbeds. The upper stratified diamictite has a reddish, siliciclastic matrix, and non-carbonate clast lithologies are dominant. Ice-rafting in the upper unit is evidenced by lonestones up to boulder size and till clots in fine-grained sandstone beds. The varied and abundant carbonate clasts in the Cottons Breccia (including oolite) may be regarded as exotic since similar lithologies are unknown in the older units on King Island. 
The Cottons Breccia is overlain more or less abruptly by the Cumberland Creek Dolostone, of welllaminated, pale grey, yellow-weathering dolostone, passing up into flaggy, thinly interbedded dolostone and shale, then limestone and shale, about $10 \mathrm{~m}$ thick in total. Tepee-like structures are present in the lower part of the unit. Carbonate carbon isotopic compositions are ${ }^{13} \mathrm{C}$-depleted and decrease upward $\left(\delta^{13} \mathrm{C}-1.9\right.$ to $-5.0 \%$ : Calver \& Walter, 2000). The Cumberland Creek Dolostone is isotopically, petrographically and sedimentologically almost indistinguishable from the Nuccaleena Formation of South Australia, the 'cap carbonate' of the glacigene Elatina Formation. Correlation of the Cottons Breccia with the Elatina Formation is therefore supported here (Calver \& Walter, 2000; Preiss, 2000; Calver et al., 2004; Hoffman et al., 2007), although it must be noted that there is dissenting opinion (Direen \& Jago, 2008). In South Australia, age constraints on this unit (whose base defines the base of the Ediacaran System) are very poor, but putative correlatives in China and Namibia are $635 \mathrm{Ma}$ (Hoffman et al., 2004, Condon et al., 2005).

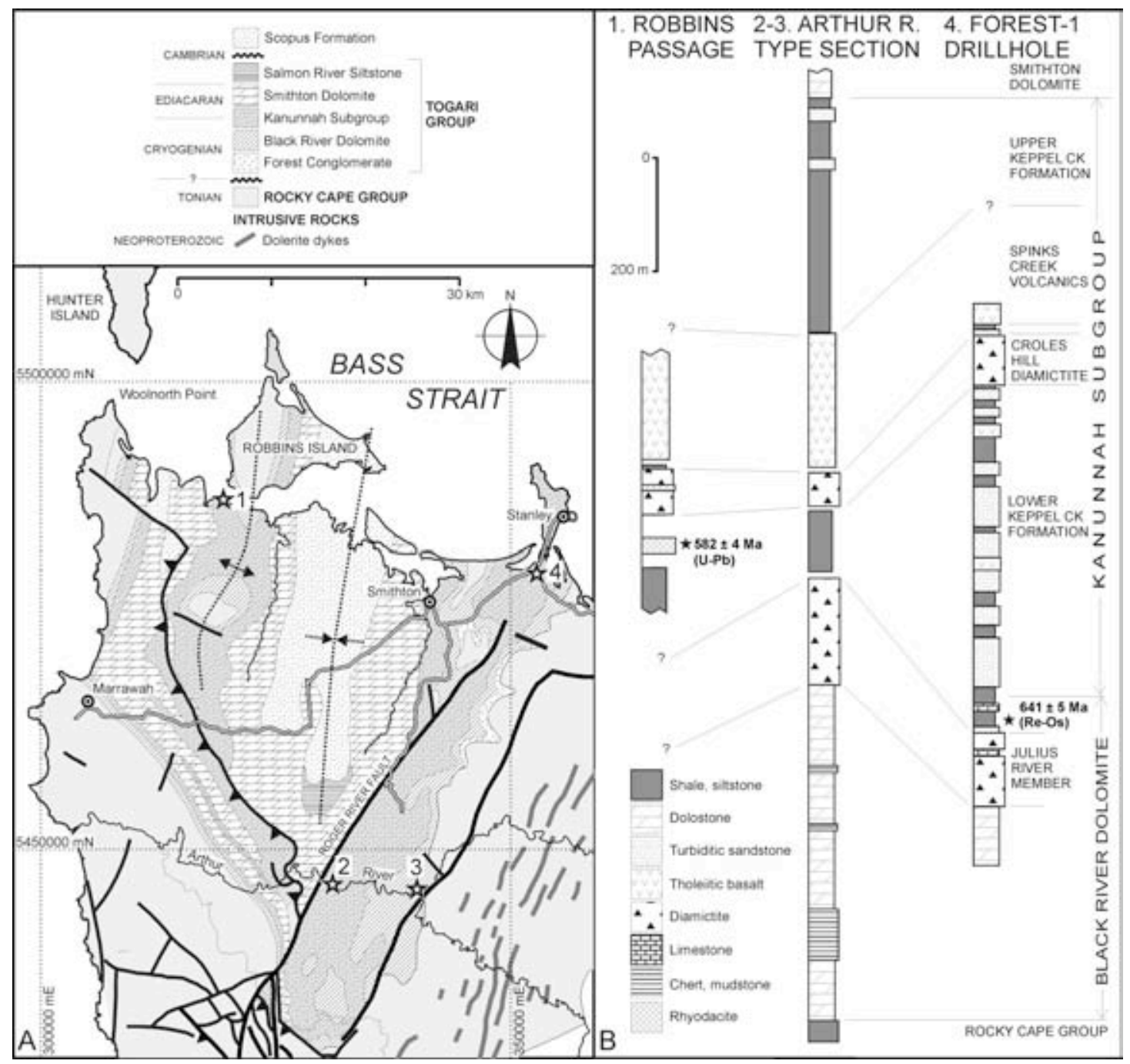

Fig. 9.2. A: Bedrock geological map of northwest Tasmania; B: stratigraphic sections at localities shown as numbered asterisks in $\mathrm{A}$.

The Cumberland Creek Dolostone is gradationally overlain by a formation of grey-green and black, then red, shale (Yarra Creek Shale). Black shale beds near the middle of the unit have a microfabric characteristic of benthic microbial mats (Calver \& Walter, 2000). Similar beds comprise a widespread but impersistent facies near the base of the Ediacaran in the Adelaide Geosyncline and Amadeus Basin (Logan et al., 1999), supporting the Elatina-Cottons correlation. Movement on NWtrending faults occurred during or just after deposition of the Yarra Creek Shale, its thickness varying from a minimum $\sim 20 \mathrm{~m}$ to $\sim 150 \mathrm{~m}$ in different fault blocks. The Robbins Creek Formation, Cottons 
Breccia and lower Yarra Creek Shale are intruded by a gently transgressive, differentiated sill of intermediate composition, the Grimes Intrusive Suite (Meffre et al., 2004). The age of this unit (575 \pm 3 Ma: U-Pb SHRIMP on zircon: Calver et al., 2004) is a minimum constraint on the age of the Cottons Breccia and hence the Elatina glaciation. The sill of Grimes Intrusive Suite varies in thickness $(15-150 \mathrm{~m})$, approximately inversely with the thickness of Yarra Creek Shale in different fault blocks, suggesting that its intrusion was related to, and in part the cause of, the fault movements that affected the Yarra Creek Shale (Calver in prep.). The succeeding City of Melbourne Volcanics, of tholeiitic pillow lavas and volcaniclastics, is little affected by penecontemporaneous fault movement and overlies the Yarra Creek Shale with local peperitic contacts indicating extrusion and shallow intrusion into soft sediment. Two higher volcanic units, of picrites and tholeiites, are the youngest exposed parts of the Grassy Group and have been dated at $579 \pm 16 \mathrm{Ma}$ (Nd-Sm isochron, Meffre et al., 2004). If the Elatina Formation and Cottons Breccia are $\sim 635 \mathrm{Ma}$ as suggested by dating of overseas correlatives, then a $\sim 50 \mathrm{~m}$.y. stratigraphic break or condensed section must lie within the Yarra Creek Shale. No physical evidence for such a break has been found, although exposure is incomplete. Alternatively, the Grimes Intrusive Suite and volcanic units may be only slightly younger than the Cottons Breccia and Elatina Formation (Calver et al., 2004).

In north-west Tasmania (Fig. 9.2), the Cryogenian to early Cambrian Togari Group unconformably overlies the early Neoproterozoic Rocky Cape Group and contains two diamictite units that have been correlated with the Sturtian and Gaskiers glacials (Calver et al., 2004; Kendall et al., 2007). In the Togari Group, a basal conglomerate is followed by shallow-marine dolostone with stromatolites and vase-shaped microfossils. Carbon isotopes are consistent with correlation with the Burra Group $(<777$ Ma: Preiss, 2000) of South Australia. A diamictite unit up to $200 \mathrm{~m}$ thick, known as the Julius River Member, overlies the dolostone with probable erosional disconformity. This is an open-framework diamictite with clasts up to $2 \mathrm{~m}$, dominantly of dolostone similar to the underlying sequence, in a dark grey dolomitic mudstone matrix. The diamictite is overlain by $5 \mathrm{~m}$ of black, impure dolostone then black shale with minor carbonate. These rocks are lithologically similar to the sequence overlying the type Sturtian glacials in South Australia, and in support of this correlation, the black shale has yielded a Re-Os date of $641 \pm 5 \mathrm{Ma}$, identical (given $2 \sigma$ uncertainties) to the $643 \pm 2 \mathrm{Ma}$ Re-Os age for the Sturtian post-glacial Tindelpina Shale Member (Kendall et al., 2007).

The black shale above the Julius River Member is gradationally overlain by the lowermost unit of the Kanunnah Subgroup. This unit (shale and siltstone; in places with turbiditic volcaniclastic sandstone) is overlain disconformably by the Croles Hill Diamictite. The Croles Hill Diamictite, up to $110 \mathrm{~m}$ thick, consists of open-framework diamictite with clasts up to $1 \mathrm{~m}$ in size, of basalt, felsic volcanics, sandstone, dolostone and chert, in a matrix of dark grey-green silty mudstone. Locally the matrix is laminated, and the clasts occur as sparse, small $(<20 \mathrm{~mm})$ lonestones and possible dropstones. At Robbins Passage (Fig. 9.2), two rhyodacite flows are found at the base and within the diamictite; that at the base is $582 \pm 4 \mathrm{Ma}$ (U-Pb SHRIMP on zircon, Calver et al., 2004). The diamictite is evidently equivalent or nearly so to the glaciogenic Gaskiers Formation of Newfoundland (580 Ma: Bowring et al., 2003). The Croles Hill Diamictite is overlain by 10 to $23 \mathrm{~m}$ of dominantly red to grey shale: no 'cap carbonate' is present. Then follows a thick (up to $250 \mathrm{~m}$ ) unit of tholeiitic basalt, more shale and siltstone, then the $1500 \mathrm{~m}$ thick Smithton Dolomite. The ${ }^{87} \mathrm{Sr} /{ }^{86} \mathrm{Sr}$ trend in the Smithton Dolomite indicates a middle to upper Ediacaran age for that unit (Calver, 1998).

The most straightforward correlation between King Island and northwest Tasmania has the Cottons Breccia equivalent to the Croles Hill Diamictite, carrying the implication of a 580 Ma Elatina glaciation since the Cottons-Elatina correlation appears well-founded (Calver et al., 2004). However, the mounting evidence for widespread 635 Ma putative Elatina correlatives outside Australia lends favour to an alternative correlation scheme in which the $\sim 635 \mathrm{Ma}$ Cottons/Elatina equivalent is missing at a stratigraphic break in the Togari Group (probably the erosional disconformity at the base 
of the Croles Hill Diamictite), and the 580 Ma Croles/Gaskiers equivalent is missing from the Grassy Group, at an undetected break within the Yarra Creek Shale (Fig. 9.3).
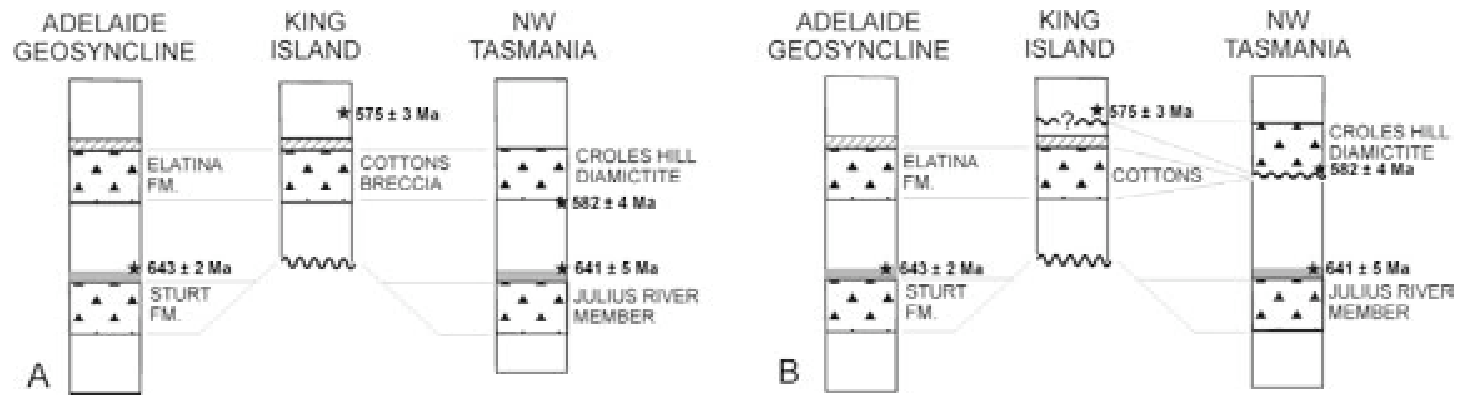

Fig. 9.3. Alternative correlation schemes for glacigene units in Adelaide Geosyncline and Tasmania. Diagonally lined band: 'Marinoan-type' cap carbonate; dark grey band: 'Sturtian-type' cap carbonate. A: after Calver et al. (2004); B: accommodates a $\sim 635$ Ma Elatina glacial.

More dating in the Australian successions is needed to resolve this issue. The latter correlation scheme suggests possible equivalence of the Croles Hill Diamictite with localised mid-Ediacaran glacigene rocks elsewhere in Australia such as the Egan Formation of the Kimberley area. Given little-altered ${ }^{87} \mathrm{Sr} /{ }^{86} \mathrm{Sr}$ of 0.7079 in the basal Smithton Dolomite, the equivalent horizon in South Australia probably lies below the Wonoka Formation (Adelaide Geosyncline) and Karlaya Formation (Officer Basin).

\section{References}

Bowring, S., Myrow, P., Landing, E., Ramezani, J. (2003). Geochronological constraints on terminal Neoproterozoic events and the rise of metazoans. Geophysical Research Abstracts 5, 219.

Calver, C.R. (1998). Isotope stratigraphy of the Neoproterozoic Togari Group, Tasmania. Australian Journal of Earth Sciences 45, $865-874$.

Calver, C.R., in prep. 1:25000 scale digital geological map series. Explanatory report for the Grassy geological map sheet.

Calver, C. R., Black, L. P., Everard, J. L., Seymour, D. B. (2004). U-Pb zircon age constraints on late Neoproterozoic glaciation in Tasmania. Geology 32, 893-896.

Calver, C.R., and Walter, M.R. (2000). The late Neoproterozoic Grassy Group of King Island, Tasmania: correlation and palaeogeographic significance. Precambrian Research 100, $299-312$.

Condon, D., Zhu, M. Y., Bowring, S., Wang, W., Yang, A. H., Jin, Y. G. (2005). U-Pb ages from the Neoproterozoic Doushantuo Formation, China. Science 308, 95-98.

Direen, N. G., Jago, J. B. (2008). The Cottons Breccia (Ediacaran), and its tectonostratigraphic context within the Grassy Group, King Island, Australia: a rift-related gravity slump deposit. Precambrian Research. doi:10.1016/j.precamres.2008.05.008

Hoffman, P.F., Halverson, G.P., Domack, E.W., Husson, J.M., Higgins, J.A., Schrag, D.P. (2007): Are basal Ediacaran (635 Ma) post-glacial “cap dolostones” diachronous? Earth \& Planetary Science Letters 258, 114-131.

Hoffmann, K.-H. , Condon, D.J. , Bowring, S.A., Crowley, J.L. (2004). U-Pb zircon date from the Neoproterozoic Ghaub Formation, Namibia: Constraints on Marinoan glaciation. Geology 32, 817-820.

Kendall, B., Creaser, R.A, Calver, C.R., Evans, D.A.D. (2007). Neoproterozoic paleogeography, Rodinia breakup, and Sturtian glaciation: Constraints from Re-Os black shale ages from southern Australia and northwestern Tasmania. Abstract, Geological Society of America.

Logan, G.A., Calver, C.R., Gorjan, P., Summons, R.E., Hayes, J.M., Walter, M.R. (1999). Terminal Proterozoic Mid-shelf Benthic Microbial Mats in the Centralian Superbasin and their Environmental Significance. Geochimica et Cosmochimica Acta 63, 1345 - 1358.

Meffre, S., Direen, N.G., Crawford, A.J., and Kamenetsky, V. (2004). Mafic volcanics on King Island, Tasmania: Evidence for plume-triggered breakup in East Gondwana at around 579 Ma.Precambrian Research 135, 177-191.

Preiss, W.V. (2000). The Adelaide geosyncline of South Australia and its significance in Neoproterozoic continental reconstruction. Precambrian Research 100, 21-63. 


\section{A Neoproterozoic Oxygenation Event?}

\section{Galen Halverson}

Geology \& Geophysics, School of Earth

\& Environmental Sciences, The University of Adelaide, SA 5005, Australia

\section{Biography:}

Galen Halverson uses sedimentology and isotope geochemistry as tools to reconstruct the evolution of ancient environments. His main focus of research is on the causes and consequences of glaciation and other global-scale environmental events in the late Precambrian. He completed his $\mathrm{PhD}$ in Geology at Harvard University in 2003 and is currently a lecturer at the University of Adelaide.

galen.halverson@adelaide.edu.au

\subsection{Introduction}

A persistent question in Earth history concerns the timing and pace of the oxygenation of the oceanatmosphere system. Geological observations (i.e. detrital uraninite and pyrite) have long been cited as evidence that Earth's earliest atmosphere lacked free oxygen (Cloud, 1972). Theoretical considerations back up this argument (Kasting, 1993; Catling and Claire, 2005), and most researchers agree based on geological grounds and geochemical data from paleosols and sediments that atmospheric oxygen remained low until the earth experienced a "Great Oxidation Event" (GOE) in the earliest Palaeoproterozoic (Holland, 2002). The sudden disappearance of non mass-dependent fractionation (NMDF) in Archean sedimentary sulphur-bearing minerals at about $2.45 \mathrm{Ga}$ (Farquhar et al., 2000; 2007; Bekker et al., 2004) confirms this major transition in the oxidation state of the earth's surface beyond any reasonable doubt.

While the GOE marked one of the most profound changes in Earth's history, it only elevated $\mathrm{pO}_{2}$ to a fraction of the present value. This increase was sufficient to drastically alter weathering patterns on the continents and change the chemistry and biology of the oceans, but not enough to oxygenate the deep oceans (Canfield, 1998; Anbar and Knoll, 2002) or sustain animal life. Thus, a second oxygenation event in the Neoproterozoic $(1000-542 \mathrm{Ma})$ is commonly invoked to account for a rise in $\mathrm{pO}_{2}$ to near modern levels, sufficient to permit the first appearance of macroscopic fauna (Runnegar, 1982; Shen et al., 2008). Although commonly accepted (though see Butterfield, 2007 for a contrasting viewpoint), this model has long been only loosely supported by compilations of sulphur isotope data on sedimentary pyrites through time (Canfield et al., 1996; Canfield, 1998)(Fig. 10.1). Recent studies have produced more convincing, though still indirect and incomplete evidence of this purported oxygenation event, placing it sometime in the middle Ediacaran Period (Fike et al., 2006; Canfield et al., 2007). Separately, Halverson and Hurtgen (2007) employed a simple sulphur isotope box model in conjunction with sulphur isotope compilations for the late Neoproterozoic - Cambrian to argue that a major oxidation event occurred around $600 \mathrm{Ma}$. However, the pattern of Neoproterozoic oxygenation was likely more complex, with irregular fluctuations in oxygen levels spanning the middle-late Neoproterozoic and modulated by major climatic and tectonic events.

\subsection{Proterozoic Oxygenation}

Geological and geochemical evidence converge to indicate an increase in atmospheric oxygen concentrations from trace levels to approximately 1-10\% present atmospheric oxygen (PAO) levels around $2.4 \mathrm{Ga}$ (Bekker et al., 2004 and references therein). Unfortunately, these indicators of atmospheric redox change (red beds, NMDF, etc.) are not sensitive to further rises in atmospheric oxygen concentrations. Evidently, oxygen concentrations must have increased to roughly modern levels by the end of the Precambrian to allow for the appearance of large animals (Runnegar, 1982), but direct evidence of an oft-cited Neoproterozoic Oxidation Event (NOE) is scarce and circumstantial. Canfield and Teske (1996) proposed a NOE occurring sometime in the latter 300 m.y. of the Neoproterozoic based on their compilation of sulphur isotope data on sedimentary pyrites and linked it to the origin of sulphur oxidising bacteria. Hurtgen et al. (2005) further constrained this 
estimate to the Ediacaran Period (635-542 Ma) based on additional coupled $\delta^{34} S_{\text {pyrite }}-\delta^{34} S_{\text {sulphate }}$ data, and it is now clear that that this event was unrelated to the origin of biogenic sulphur disproportion, which was an important component in sulphur cycling much earlier in Earth's history (Johnston et al., 2005). An oxygenation event in the Ediacaran Period has been supported by subsequent geochemical studies. Namely, iron speciation data from Newfoundland indicate deep ocean oxygenation, at least in Avalonia, around $580 \mathrm{Ma}$ (Canfield et al., 2007), while a rise in the net fractionation observed between seawater sulphate and pyrite $\left(\Delta^{34} S\right)$ in Oman (Fike et al., 2006) suggests increased oxygen availability on shallow tropical shelves at about the same time. It has yet to be established if these data reflect global ventilation of the ocean, but the roughly synchronous Shuram-Wonoka negative $\delta^{13} \mathrm{C}$ anomaly suggests that a large amount of oxidizing power was available in the oceans by this time (Fike et al., 2006).

\subsection{The Ediacaran Sulphur Isotope Record and Growth of the Marine Sulphate Reservoir}

The use of sulphur isotopes as a proxy for oxygenation of the Earth's surface environment is justified by the coupling of the sulphur and oxygen cycles. In the simplest case, $\Delta^{34} \mathrm{~S}$ is a function of oxygen availability. This linkage is due both to the direct influence of oxygen on the recycling of sulphide, which leads to higher observed $\Delta^{34} \mathrm{~S}$ due to isotope fractionations associated with disproportionation reactions (Canfield and Teske, 1996; Detmers et al., 2001) and the indirect influence of oxidative sulphide weathering on marine sulphate concentrations, which govern the magnitude of fractionation incurred during bacterial sulphate reduction of sulfphate to sulphide (Habicht et al., 2002). Unfortunately, compiling accurate and precise coupled pyrite and sulphate data is difficult and hindered by as yet poorly understood post-depositional processes that may blur the $\Delta^{34} \mathrm{~S}$ signal. However, an increase in $\Delta^{34} \mathrm{~S}$, if related to increasing $\mathrm{pO}_{2}$ and marine sulphate concentrations, should be detectable in either the pyrite or sulphate record alone. A simple box model used to explore the evolution of the Ediacaran sulphur cycle and account for the very high $\delta^{34} \mathrm{~S}_{\text {sulphate }}$ values $(\sim 40 \%$ ) that characterise the Ediacaran-Cambrian boundary (Fig. 10.1) suggests that the increase in $\Delta^{34} S$ should be recorded in negative excursions in both $\delta^{34} S_{\text {pyrite }}$ and $\delta^{34} S_{\text {sulphate }}$ as the marine sulphate reservoir begins to grow, followed by an increase to higher values as it approaches steady state. Significantly, prominent decreases in $\delta^{34} \mathrm{~S}_{\text {pyrite }}$ are observed in every Ediacaran section for which detailed data are available: South and central Australia (Gorjan et al., 2000), Oman (Fike et al., 2006), Newfoundland (Canfield et al., 2007), South China (McFadden et al., 2007), and northwestern Canada (Shen et al., 2008). Collectively, these data indicate that the marine sulphate reservoir grew rapidly in the middle Ediacaran Period, and inferentially, that $\mathrm{pO}_{2}$, began to rise prior to the onset of the Shuram-Wonoka $\delta^{13} \mathrm{C}$ anomaly (Fig. 10.1).

Why should the environment have finally become oxidized during the Ediacaran period? Notably, many early Ediacaran post-glacial successions worldwide comprise thick sections of relatively organic-rich shales, including the important source bed for Oman Q-type oils, the Masirah Bay Formation (Grantham et al., 1988). The combination of high $\mathrm{pCO}_{2}$ and associated intense chemical weathering (and thus nutrient delivery) in the aftermath of a snowball glaciation (Higgins and Schrag, 2003) would have stimulated high primary production and burial of organic carbon, and thus a pulse of $\mathrm{O}_{2}$ production. Much of this free oxygen was likely consumed by pyrite weathering on the continents, driving a rapid increase in marine sulphate concentrations (Halverson and Hurtgen, 2007). This repository of oxidizing power in the environment likely helped preserve elevated $\mathrm{O}_{2}$ levels during the long-lived Shuram-Wonoka $\delta^{13} \mathrm{C}$ anomaly, accounting for colonisation of the deep ocean by oxygen-requiring Ediacaran biota by $575 \mathrm{Ma}$ (Narbonne and Gehling, 2003). This model has the NOE preceding the first appearance of the Ediacaran fauna by several tens of millions of years (Fig. 1), which has important implications for the appearance and evolution of the earliest metazoan (Sperling et al., 2007; Shen et al, 2008). 


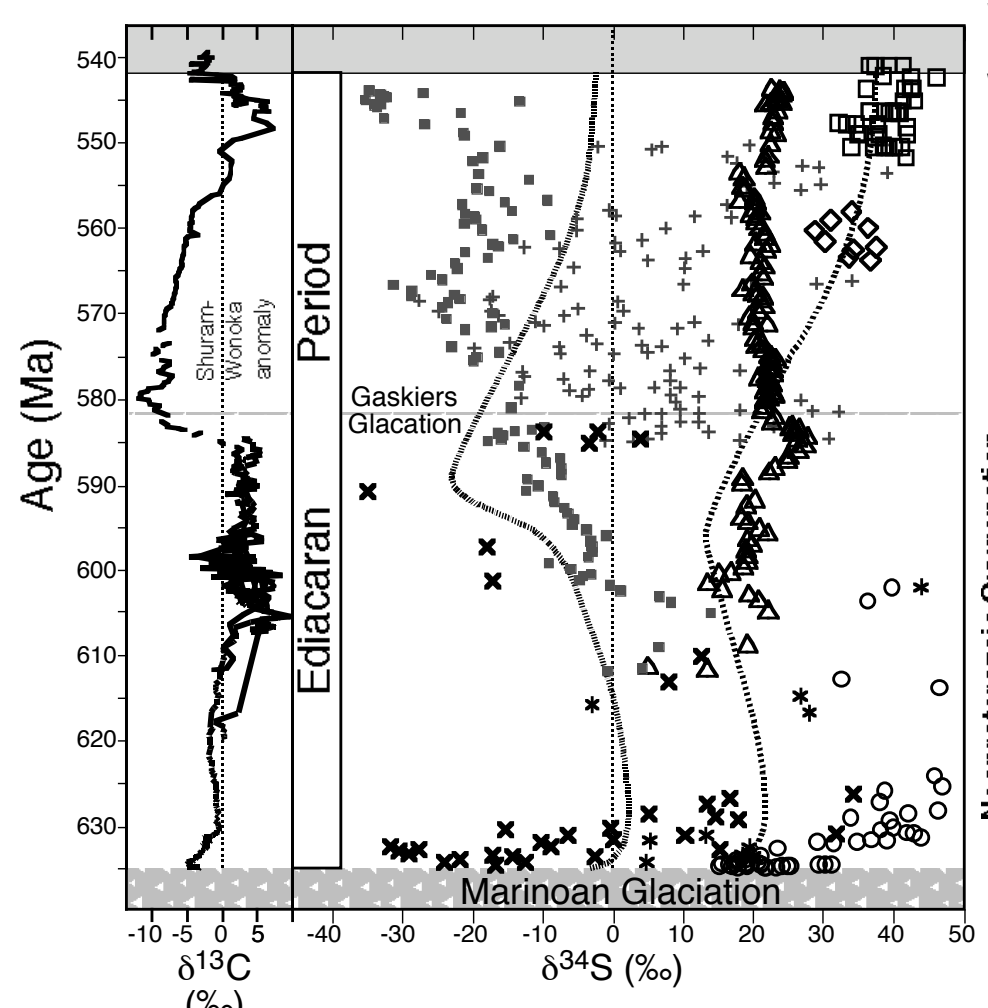

Small shelly fossils

Weakly calcified metazoa

First appearance of Ediacaran fauna

Shuram-Wonoka negative $\delta^{13} \mathrm{C}$ anomaly

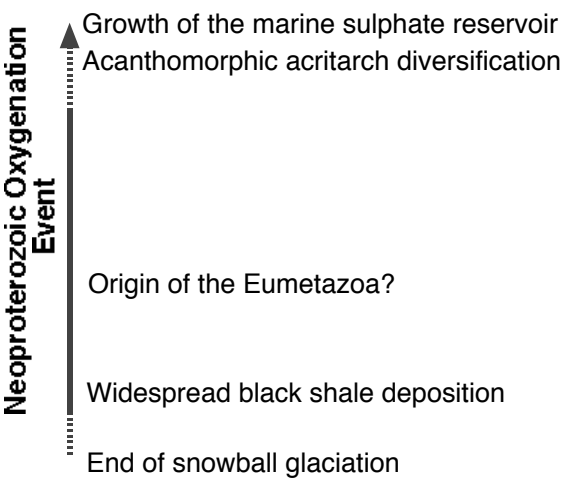

(\%०)

\begin{tabular}{r|ccccc} 
& Namibia & Oman & Australia Newfld. Siberia \\
\cline { 2 - 6 } sulphate & $\mathbf{O}$ & $\boldsymbol{\Delta}$ & & & $\diamond$ \\
pyrite & $*$ & $\mathbf{*}$ & $\mathbf{x}$ & + &
\end{tabular}

Figure 10.1. Sulphur and carbon isotopic compilations the Ediacaran period (modified from Halverson and Hurtgen, 2007). Dashed lines are modelled variations in $\delta^{34} S_{\text {pyrite }}$ (left) and $\delta^{34} S_{\text {sulphate }}$ (right) based on the premise that the marine sulphate reservoir grew rapidly in the middle early-middle Ediacaran Period. See Halverson and Hurtgen (2007) for references. The sequence of climatic, geochemical, and biological events that distinguish the Ediacaran Period are listed on the right. The Neoproterozoic Oxygenation Event (NOE) is inferred to have occurred during the first half of the Ediacaran Period, following the last snowball glaciation.

\subsection{Fluctuations in Neoproterozoic Oxygen Levels?}

A long-term rise in $\mathrm{pO}_{2}$ requires either an increase in the source of free oxygen or a decrease in reductive sinks (Holland, 2002). While various abiotic chemical reactions may produce relatively minor amounts of $\mathrm{O}_{2}$, photosynthesis and the burial of sedimentary organic matter is certainly the dominant source of $\mathrm{O}_{2}$ over geological time (Schidlowski et al., 1975). The Neoproterozoic Era, though known for its extreme negative $\delta^{13} \mathrm{C}$ anomalies (Knoll et al., 1986; Kaufman et al., 1997), is characterised by high average $\delta^{13} \mathrm{C}$ values $(\sim 5 \%$; Halverson et al., 2005)(Fig. 10.2), indicating elevated proportional burial of organic carbon burial, perhaps related to the protracted break-up of Rodinia and establishment of large, tropical sedimentary basins (Maloof et al., 2006). A pulse of calcium sulphate deposition in the middle-Neoproterozoic (Grotzinger and Kasting, 1993) and the increased variability in marine $\delta^{13} \mathrm{C}$ may be evidence for a complementary increase in the oxidation state of the atmosphere. In fact, the compilation of Neoproterozoic sulphur isotope data in Figure 10.2 reveals large systematic swings in $\delta^{34} S_{\text {pyrite }}$ that virtually all correspond to major palaeoenvironmental events, such as glaciations or prominent $\delta^{13} \mathrm{C}$ anomalies. Extrapolating the modelling of Halverson and Hurtgen (2007), negative shifts in $\delta^{34} S_{\text {pyrite }}$ at ca. 815, 750, 675, and 580 Ma may all record times at which the marine sulphate reservoir grew from concentrations of less then $1 \mathrm{mM}$ to at least several $\mathrm{mM}$. Conversely, sharp increases in $\delta^{34} S_{\text {pyrite }}$ (and decreases in average $\Delta^{34} \mathrm{~S}$ ), such as occur prior to the two Cryogenian glaciations and across the Precambrian-Cambrian boundary, may record shrinkage of the marine sulphate reservoir. If this interpretation is correct, then it implies that oxygen concentrations fluctuated significantly throughout the Neoproterozoic. Interestingly, the pattern in the diversity of acritarchs, which likely represent eukaryotic algae sensitive to oxygen availability 
(Tappan, 1980), broadly varies in parallel to this trend, with the latter Cryogenian being especially depauperate. While the resolution in Neoproterozoic biostratigraphic data is as yet too low to establish an unequivocal correlation between biospheric evolution and secular variations in the sulphur isotope record, it is sufficient to suggest that fluctuations in atmospheric and oceanic oxygen levels likely played a fundamental role in eukaryotic innovations and biospheric evolution throughout the Neoproterozoic, beginning well in advance of the first appearance of the Ediacaran biota.

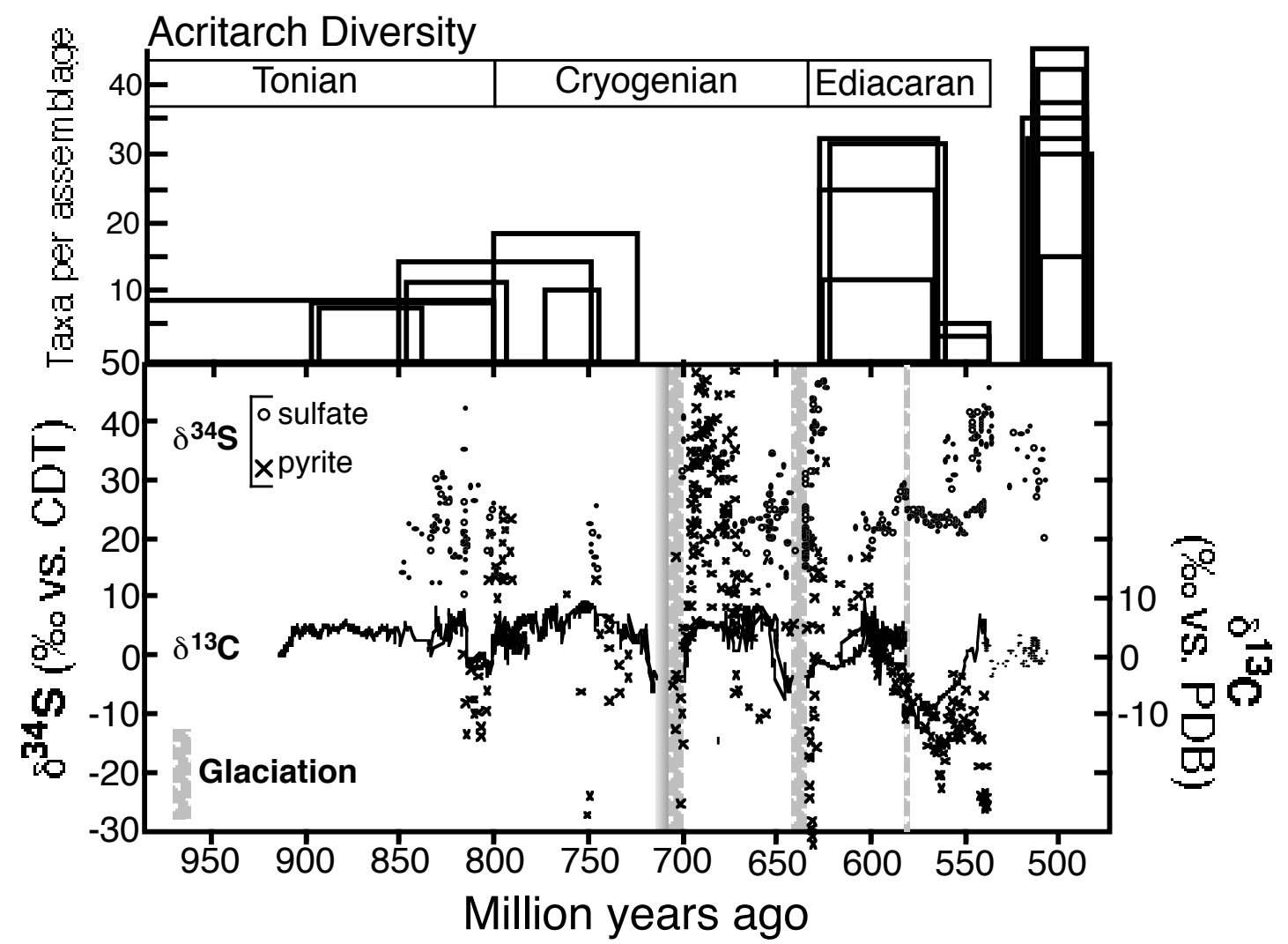

Figure 10.2. Acritarch diversity (modified from Knoll et al., 2006) and a compilation of $\delta^{13} \mathrm{C}$ (carbonate) and $\delta^{34} \mathrm{~S}$ (pyrite and sulfate) through the Neoproterozoic Era (modified from Halverson and Hurtgen, 2007, with additional data from Gorjan et al., 2001 and Fike et al., 2006). Note the absence of microfossil data from 720-630 Ma and complete lack of data coverage for the earliest Neoproterozoic. While there is little $\delta^{34} \mathrm{~S}$ data for the first half of the Neoproterozoic, sustained high average $\delta^{13} \mathrm{C}$ values are consistent with increasing oxygen levels prior to the first glaciation. Qualitatively, variations in oxygen levels thereafter can be inferred from the average $\Delta^{34} \mathrm{~S}$ (Canfield, 1998), which fluctuates significantly from about 825 to 540 Ma.

\subsection{References}

Anbar, A. Knoll, A. (2002). Proterozoic ocean chemistry and evolution: A bioinorganic bridge? Nature 297, 1137-1142.

Bekker, A., Holland, H.D., Wang, P.-L., Rumble, D. III, Stein, H., Hannah, J., Coetzee, L., Beukes, N.J. (2004). Dating the rise of atmospheric oxygen. Nature 427, 117-120.

Butterfield, N.J. (2007). Macroevolution and macroecology through deep time. Palaeontology 50, 41-55.

Canfield, D.E. (1998). A new model for Proterozoic ocean chemistry. Nature 396, 450-453.

Canfield, D.E., Poulton, S., Narbonne, G. (2007). Late-Neoproterozoic deep-ocean oxygenation and the rise of animal life, Science 315, 92-95.

Canfield, D.E., Teske, A. (1996). Late Proterozoic rise in atmospheric oxygen concentration inferred from phylogenetic and sulphur-isotope studies, Nature 382, 127-132.

Catling, D., Claire, M. (2005). How Earth's atmosphere evolved to an oxic state: A status report, Earth and Planetary Science Letters 237, 1-20.

Cloud, P. (1972). A working model of the primitive earth, American Journal of Science 272, 537-548.

Detmers, J., Bruüchert, V., Habicht, K., Kuever, J. (2001). Diversity of sulfur isotope fractionations by sulfate-reducing prokaryotes. Applied and Environmental Microbiology 67, 888-894.

Farquhar, J., Bao, H., Thiemens, M., (2000). Atmospheric influence of Earth's earliest sulfur cycle. Science 289, 756-758.

Farquhar, J., Peters, M., Johnston, D.T., Strauss, H. Masterson, A., Wiechert, U., Kaufman, A.J. (2007). Isotopic evidence for Mesoarchean anoxia and changing atmospheric sulphur chemistry. Nature 449, 706-709. 
Fike, D., Grotzinger, J., Pratt, L., Summons, R. (2006). Oxidation of the Ediacaran Ocean. Nature 444, 744-747.

Gorjan, P., Veevers, J. J., Walter, M. R. (2000). Neoproterozoic sulfur-isotope variation in Australia and global implications, Precambrian Research, 100, 151-179.

Grotzinger, J.P., Kasting, J.F. (1993). New constraints on Precambrian ocean composition, Journal of Geology 101, 235-243.

Habicht, K.S., Cade, M., Thamdrup, B., Berg, P., Canfield, D.E. (2002). Calibration of sulfate levels in the Archean ocean, Science 298, 2372-2374.

Halverson, G.P., Hoffman, P.F., Schrag, D.P., Maloof, A.C., Rice, A.H., (2005). Towards a Neoproterozoic composite carbon isotope record, Geological Society of America Bulletin 117, 1181-1207.

Halverson, G. and Hurtgen, M. (2007). Ediacaran growth of the marine sulfate reservoir, Earth and Planetary Science Letters 263, 32-44.

Higgins, J.A., Schrag, D.P. (2003). Aftermath of a snowball Earth, Geochemistry, Geophysics, Geosystems 431 , $10.1029 / 2002 G C 000403$.

Holland, H.D., 2002. Volcanic gases, black smokers, and the great oxidation event. Geochimica et Cosmochimica Acta 66, 3811-3826.

Hurtgen, M.T., Halverson, G.P., Arthur, M.A., Hoffman, P.F. (2006). Sulfur cycing in the aftermath of a Neoproterozoic (Marinoan) snowball glaciation: Evidence for a syn-glacial sulfidic deep ocean, Earth and Planetary Science Letters 245, 551-570.

Johnston, D.T., Wing, B.A., Farquhar, J., Kaufman, A.J., Strauss, H., Lyons, T.W., Kah, L.C., Canfield, D.E. (20

Kasting, J.F. (1993). Earth's early atmosphere. Science 259, 920-926.

Kaufman, A. J., Knoll, A. H., Narbonne, G. M. (1997). Isotopes, ice ages, and terminal Proterozoic Earth history. Proceedings of the National Academy of Sciences 95, 6600-6605.

Knoll, A. H., Javaux, E. J., Hewitt, D., Cohen, P. (2006). Eukaryotic organisms in Proterozoic oceans, Philosophical Transactions of the Royal Society of London 361, 1023-1038.

Knoll, A. H., Hayes, J. M., Kaufman, A. J., Swett, K., Lambert, I. B. (1986). Secular variation in carbon isotope ratios from Upper Proterozoic successions of Svalbard and east Greenland. Nature 321, 832-837.

Maloof, A. C., Halverson, G. P., Kirschvink, J. L., Schrag, D. P., Weiss, B., Hoffman, P. F. (2006). Combined paleomagnetic, isotopic and stratigraphic evidence for true polar wander from the Neoproterozoic Akademikerbreen Group, Svalbard. Geological Society of America Bulletin 118, 1099-1124.

McFadden, K. A., Huang, J., Chu, X., Jiang, G., Kaufman, A. J., Zhou, C., Yuan, X., Xiao, S. (2008). Pulsed oxidation and biological evolution in Ediacaran Doushantuo Formation, Proceedings of the National Academy of Sciences 105, 3197-3202.

Narbonne, G. Gehling, J. (2003). Life after snowball: The oldest complex Ediacaran fossils, Geology 31, 27-30.

Runnegar, B. (1982). Oxygen requirements, biology and phylogenetic significance of the late Precambrian worm Dickinsonia, and the evolution of the burrowing habit, Alcheringa 6, 223-239.

Schidlowski, M., Eichmann, R., Junge, C.E. (1975). Precambrian sedimentary carbonates: carbon and oxygen isotope geochemistry and implications for the terrestrial oxygen budget, Precambrian Research 2, 1-69.

Shen, Y., Zhang, T., Hoffman, P.F. (2008). On the coevolution of Ediacaran Oceans and oxygen. Proceedings of the National Academy of Sciences 105, 7376-7381.

Sperling, E., Pisani, D., Peterson, K.J. (2007). Poriferan paraphyly and its implications for Precambrian palaeobiology, in P. Vickers-Rich and P. Komarower (Eds.), The Rise and Fall of the Ediacaran Biota, Geological Society of London, v. 286, 355-368.

Tappan, H. (1980). The Paleobiology of Plant Protists. Freeman, San Francisco, 224 p. 
NOTES: 


\section{Supermountains, Hendrix and the oxygen-rich elixir of animal life}

Richard J. Squire ${ }^{1}$

\&

Ian H. Campbell ${ }^{2}$

${ }^{1}$ School of Geoscience

Monash Uni. VIC 3800

Rick.Squire@sci.monash.edu.au

${ }^{2}$ RSES, Aust. National Uni.

Canberra, ACT, 0200

\section{Biography:}

Rick Squire is field geologist who specialises in volcanology and thinks he's still a chance of winning a hill stage in the Tour de France. When not dreaming of his victory in The Alps, he's investigating tectonic controls on generation of world-class ore deposits. He is also interested in geological controls on extreme environmental and biological events in Earth's history such as the 'Big Bang' in animal evolution. Vive le Tour.

What triggered the "Big Bang" in animal evolution? This question has challenged scientists since Charles Darwin's proposal, some 149 years ago, that animals evolved by descent with modification (Darwin 1859). Much of the recent research on this topic has focussed on the rise of oxygen concentrations in Earth's upper oceans (Canfield et al. 2007; Fike et al. 2006). While the results from isotopic analyses of ancient carbonate rocks indicate that the oxygen concentrations in Earth's oceans rose dramatically between about 600 and 580 million years ago (Halverson and Hurtgen 2007), it remains unclear what caused this extreme shift in environmental conditions. Here, we suggest that extreme erosion of the largest mountain range in Earth's history (the Transgondwanan Supermountains; Figure 11.1) not only provided a huge flux of the nutrients that are essential for complex life (Squire et al. 2006), but also triggered the dramatic increase in oceanic oxygen concentrations that were crucial for animals to flourish. The vital clues for this discovery are not only found in the voluminous continentally derived quartz-rich sedimentary succession eroded from the gigantic mountain range, but in the lyrics to Jimi Hendrix best-known hit song.

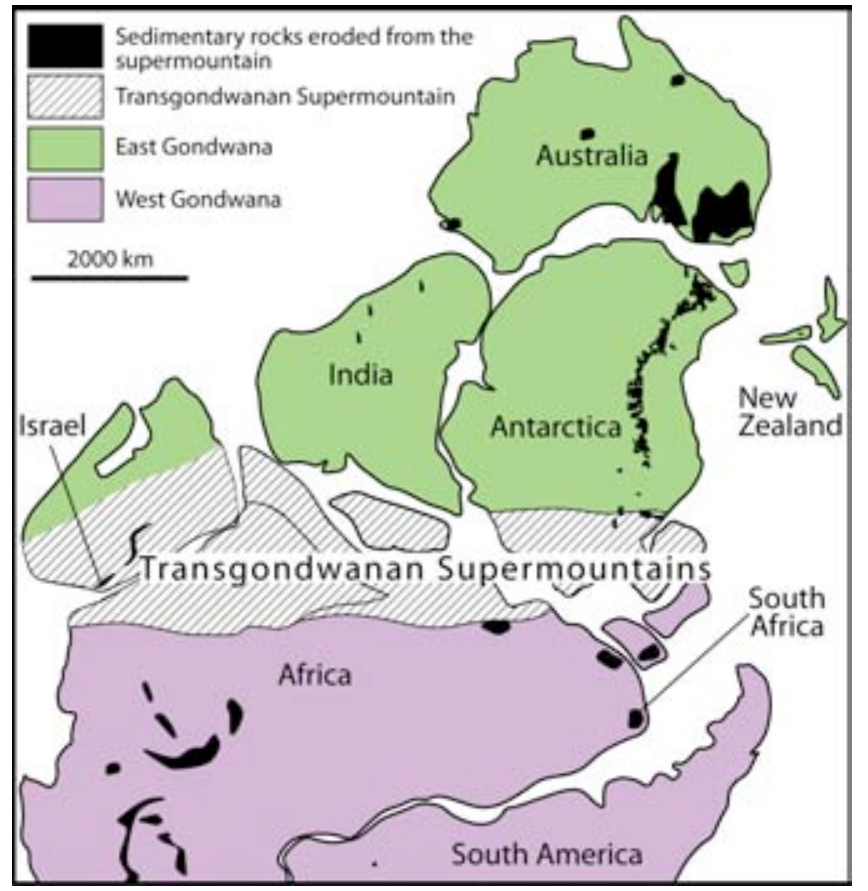

Fig 11.1. Simplified map showing the location of the Transgondwanan Supermountains and the distribution of early Palaeozoic continentally derived quartz-rich sedimentary rocks eroded from the gigantic range (modified after Squire et al. 2006).

To understand how the concentration of oxygen in Earth's oceans increased, it is easiest to consider how oxygen builds up in the atmosphere. Today, photosynthesis is responsible for the generation of most of the oxygen in Earth's atmosphere (Lane 2002). This process proceeds when photosynthesising organisms like plants react carbon dioxide and water in the presence of sunlight to generate sugar and oxygen. The uncontrolled build-up of oxygen in Earth's atmosphere is hindered by the numerous processes that consume oxygen, and the most important of these is the respiration of 
animals, fungi and bacteria. When respiring organism react sugar with oxygen they give off carbon dioxide and water in a reaction that is almost the exact opposite of photosynthesis. In today's the upper ocean, where photosynthesising organisms live, similar processes occur that result in the oxygenation of those waters (Lane 2002).

Dramatic increases in the levels of oceanic oxygen; such as occurred during the Ediacaran period, can only be achieved when the rates of oxygen production are much higher than the rates of oxygen consumption. Such an imbalance is best achieved by preventing organic matter that was generated by photosynthesis, from reacting with oxygen when it dies. For example, if a plant dies and quickly sinks into an anoxic swamp or deep ocean, respiring organisms are unable to consume it. Rapid burial of the plant will also prevent anaerobic processes from breaking the material down. The re-uptake of oxygen generated by the organism during photosynthesis is thereby prevented and an excess of oxygen accumulates. If this process occurs on a large scale, there will be a marked increase in the concentration of oxygen in the atmosphere (or upper ocean).

Although coal deposits are well-known examples of the remains of buried organisms, the mosteffective way to bury large volume of organic matter is in the sedimentary rocks eroded from huge mountain ranges (Lane 2002). Despite the low concentrations of organic material, the enormous volume of rocks being deposited in remnant-ocean basins such as the Bengal Fan (Fergusson and Coney 1992) far exceeds that which accumulates in any swampland. Therefore, erosion of huge mountain ranges like the Himalayas will produce marked increases in the concentration of oxygen in Earth atmosphere and oceans. The growth and extreme erosion of the 8,000-km-long and up to 1,500km-wide Transgondwanan Supermountains between about 635 and 515 Ma must have had a dramatic impact on oxygen concentrations at this time.

Previously, we showed how the quartz-rich sedimentary rocks eroded from the Transgondwanan Supermountains totalled at least 100 million $\mathrm{km}^{3}$, which is enough material to cover the entire U.S. with about $10 \mathrm{~km}$ of material (Squire et al. 2006). As we pointed out, the dramatic rise in ${ }^{87} \mathrm{Sr} /{ }^{86} \mathrm{Sr}$ values in seawater during this period supports an episode of extreme erosion. Coincident with these changes was a huge flux of $\mathrm{Fe}, \mathrm{P}, \mathrm{Ca}$ and bicarbonate ions into the oceans. Fe is need to facilitate electron-transfer reactions essential for $\mathrm{N}$-fixing bacteria, $\mathrm{P}$ is an essential component of DNA and $\mathrm{Ca}$ and bicarbonate ions are required for skeletons. This huge flux of nutrients down the rivers draining the gigantic mountain chain produced an unprecedented expansion of primitive life forms (especially algae). In addition to these essential nutrients, unprecedented rates of burial of sedimentary rocks eroded from the Transgondwanan Supermountains prevented huge volumes of organic matter from back-reacting with oxygen. As a consequence, oxygen was released into the upper ocean. The rise of animals was thus the extreme biological response to the highly potent oxygen-rich elixir generated by the growth and extreme erosion of the largest mountain range in Earth's history.

And how does all this relate to Jimi Hendrix and his best-know song? Come along to our presentation and find out.

\section{References}

Canfield, D.D., Poulton, S.W., Narbonne, G.M. (2007) Late-Neoproterozoic Deep-Ocean Oxygenation and the Rise of Animal Life. Science 315, 92-95.

Darwin, C. (1859) On the origin of species by means of natural selection. John Murray, London. p 502.

Fergusson, C.L, Coney, P.J. (1992) Implications of a Bengal Fan-type deposit in the Paleozoic Lachlan Fold Belt of southeastern Australia. Geology 20, 1047-1049.

Fike, D.A., Grotzinger, J.P., Pratt, L.M., Summons, R.E. (2006) Oxidation of the Ediacaran Ocean. Nature, 444, $744-747$.

Halverson, G.P., Hurtgen, M.T. (2007) Ediacaran growth of the marine sulfate reservoir. Earth and Planetary Science Letters 263, 32-44.

Lane, N. (2002) Oxygen: the molecule that made the world. Oxford University Press, Oxford.

Squire, R.J., Campbell, I.H., Allen, C.M., Wilson, C.J.L. (2006) Did the Transgondwanan Supermountains trigger the explosive radiation of animals on Earth? Earth and Planetary Science Letters 250, 116-133. 


\section{Age constraints for the Sturtian Glaciation; data from the Adelaide Geosyncline, South Australia and Pocatello Formation, Idaho, USA.}

\author{
C. Mark Fanning \& Paul K. \\ Link
}

Research School of Earth

Sciences, The Australian

National University, Mills

Road, Acton, ACT 0200

Mark.Fanning@anu.edu.au

Department of Geosciences,

Idaho State University,

Pocatello, ID 83209-8072, USA.

linkpaul@isu.edu

\section{Biography:}

Mark Fanning is a Senior Fellow and Manager Prise at RSES, ANU. He has over 30 years experience in radiogenic isotope systems, predominantly $\mathrm{U}-\mathrm{Pb}$ on zircons.

Paul Link is a Professor in the Department of Geosciences, Idaho State University, Pocatello. He is a sedimentologist who has spent over 30 years looking at Neoproterozoic sequences; his interests include stratigraphy and basin analysis.

A fundamental criterion of the Snowball earth hypothesis is the global synchronicity of the sedimentary record. Globally, rocks of the Cryogenian interval (800 to $550 \mathrm{Ma}$ ) contain glaciomarine diamictite and associated carbonates that have been subjected to numerous detailed geochemical studies (Sr-, C-, and S-isotopes). The resulting chemostratigraphic curves for the Neoproterozoic have revolutionized our understanding of paleooceanography and paleoclimatology, though correlation issues are contentious (Halverson, 2006). Significantly, these detailed and extensive geochemical studies generally lack a credible geochronology. This prohibits rigorous testing of the Snowball Earth hypotheses. The purpose of this presentation is to critically examine some of the geochronologic data.

There can be little doubt that the high precision thermal ionisation mass spectrometric (TIMS) dating of zircons from Marinoan sequences in China and Namibia record isochronous events. In Namibia, Hoffmann et al (2004) report an age of 635.5 \pm 1.2 Ma for an ash bed from the glaciogenic Ghaub Formation that has negative $\delta^{13} \mathrm{C}$ excursions. This age is indistinguishable from that by Condon et al. (2005) in south China where an age of $635.2 \pm 0.6 \mathrm{Ma}$ is reported for an ash within the Lower Dolomite Member of the Doushantuo Formation. This date constrains the time of cap carbonate formation and the end of the Nantuo glaciation. Clearly these two Marinoan sequences from widely separated locations are synchronous and constrain a "global" Marinoan Snowball event at 635 Ma.

The concept of a single, presumed synchronous, "Sturtian glaciation" also has been interpreted or used uncritically in many Snowball earth discussions dealing with Neoproterozoic paleoclimatology and tectonics. This single Sturtian glaciation has been thought to be as old as 770 to $735 \mathrm{Ma}$ (Key et al., 2001) and ca.715 Ma (Zhou et al., 2004), 711.52 $\pm 0.20 \mathrm{Ma}$ (Bowring et al., 2007), ca.685 Ma (Lund et al., 2003), to ca.665 Ma (Fanning and Link, 2004). There are also suggestions that $720 \mathrm{Ma}$ is the age of the Sturtian glacial deposits in South Australia; the latter is not based on hard geochronologic data (i.e. U-Pb zircon age determination). In fact, reliable ages on world-wide correlated Sturtian glacial rocks are sparse. This presentation will review recent, and present new data from Idaho, USA and South Australia.

In southeastern Idaho the Sturtian glacial portion of the Pocatello Formation was seen by Fanning and Link (2004) to be younger than ca.717 Ma (volcanic clast within diamictite of the Pocatello Formation; see Fig. 12.1) and older than $667 \pm 5$ Ma (tuffaceous layer above cap carbonate; see Fig. 9.2a). Elsewhere in Idaho, an epiclastic plagioclase-phyric tuff breccia immediately below glaciogenic 
Scout Mountain Member diamictite on Oxford Mountain, yielded a SHRIMP U-Pb concordia age of $709 \pm 5$ Ma (Fanning and Link, 2004; Fig. 12.1). A re-examination of this section and new data produces a revised age of $686 \pm 4 \mathrm{Ma}$ (Fig. 12.1); the original SHRIMP date appears to be in error. There is extensive Sevier age thrusting within this section and so the exact stratigraphic position of the felsic volcanic rock is less well constrained than initially thought.

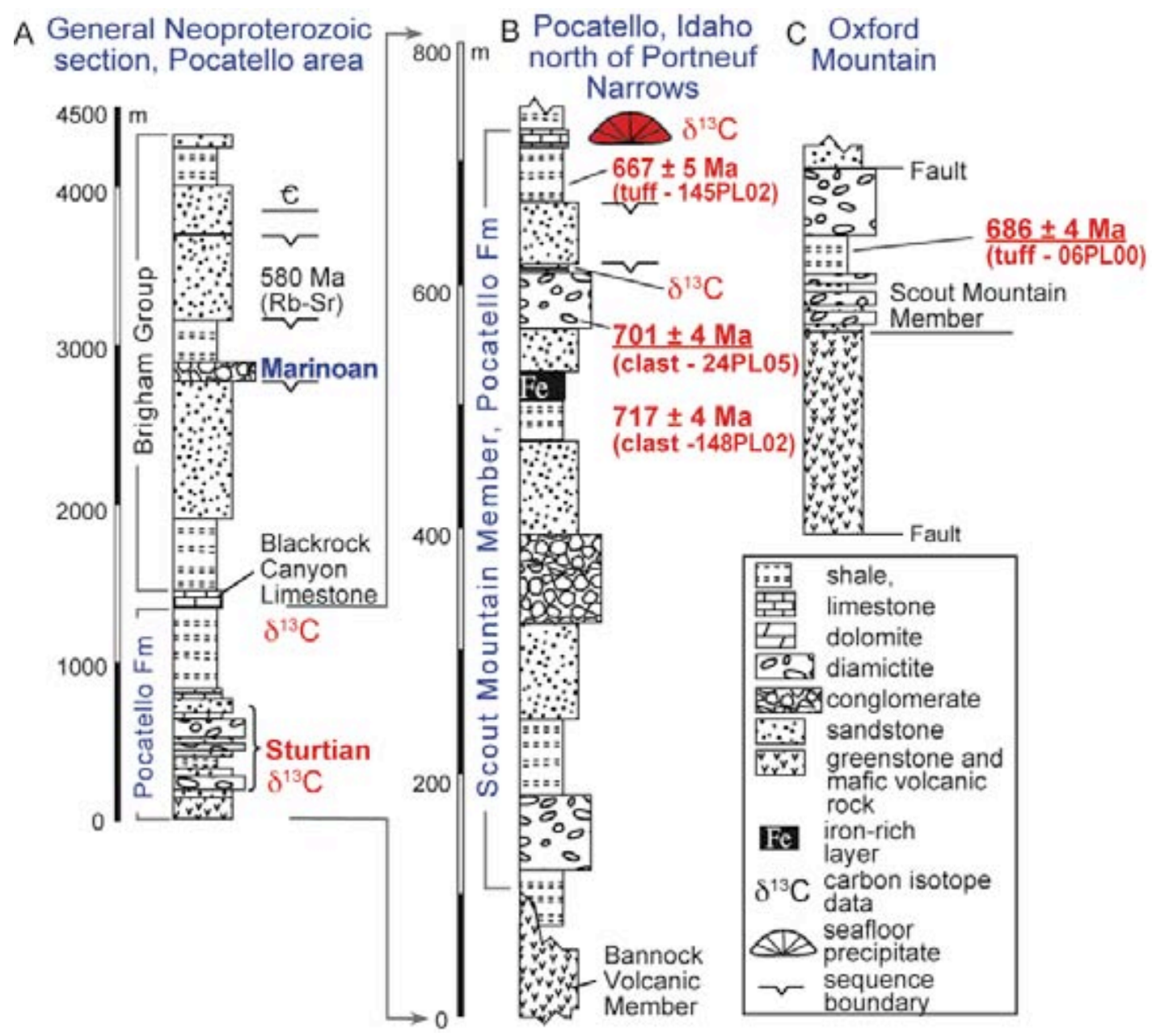

Fig.12.1 Stratigraphic columns modified from Fanning and Link (2004). A: Entire Neoproterozoic section in the Pocatello area. B: Detail of Pocatello Formation stratigraphy in Pocatello area, showing locations of previously dated samples and new clast 24PL05. C: Pocatello Formation stratigraphy on Oxford Mountain, showing revised date for this felsic volcanic horizon. Locations are shown for the carbon isotope data of Smith et al. (1994) and Lorentz et al. (2004).

Further sampling of felsic volcanic clasts within the Pocatello Formation at Portneuf Narrows revises the maximum age constraint on the glaciation to $701 \pm 4 \mathrm{Ma}$ (clast sample 24PL05; Fig. 12.2b). The time of Sturtian glaciation in Idaho is between $667 \pm 5 \mathrm{Ma}$ and $701 \pm 5 \mathrm{Ma}$, though may be younger than $686 \pm 4 \mathrm{Ma}$ depending on the results of further detailed mapping and stratigraphic interpretation of the Oxford Mountain sequence. 


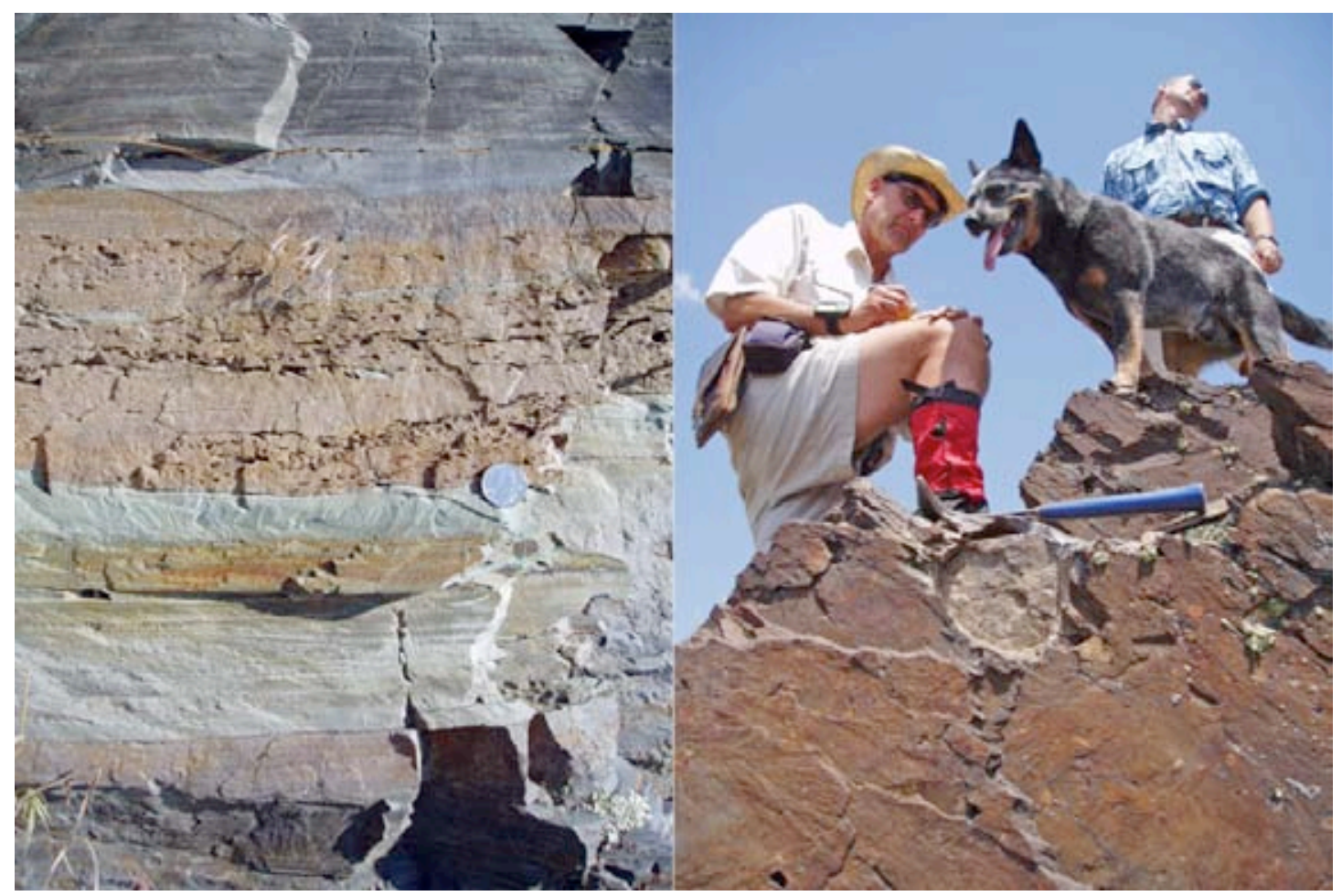

Fig 12.2. Field photographs from the Portneuf Narrows, Pocatello, Idaho USA. Photo a. shows a greenish, porcellaneous, $10 \mathrm{~cm}$ tuff bed dated at $667 \pm 5$ Ma that occurs between the cap and caplike carbonates in the uppermost part of the Scout Mountain Member. Photo b. shows the felsic volcanic last 24PL05 dated at $701 \pm 4$ Ma. Paul Link and Blue Heeler Moxie for scale.

The Adelaide Geosyncline in South Australia is the conceptional birth place for the world-wide Neoproterozoic nomenclature: Sturtian, Marinoan, Ediacaran. Glacial strata at Sturt Gorge were first recognised by Howchin (1901). Preiss (1987 and 2000) and Preiss et al. (1998) provided key summaries and overviews for the entire Adelaide Geosyncline and Stuart Shelf (see Preiss, this volume for an update).

Geochronological constraints for the SA Adelaidean sequence are minimal. Basal mafic volcanics, interpreted to document the onset of the initial rift, are considered to be coeval with the Gairdner dyke swarm of the Stuart Shelf dated at $827 \pm 6 \mathrm{Ma}$ (Wingate et al. 1998). A lithic crystal tuff, the Rook Tuff from the Willouran Ranges is one of only two felsic volcanic rocks interbedded with Adelaidean sediments, as currently identified. A TIMS date of $802 \pm 10 \mathrm{Ma}$ is given in abstract by Fanning et al. (1986; see Fig. 12.3). The Boucaut Volcanics from the Nackara Arc are interpreted to belong to the Burra Group. Preiss (2000) cites the number $777 \pm 7$ Ma (as pers comm. from Fanning); though this can hardly be considered a reliable date (see Fig. 12.3). An even more tenuous use of U-Pb data has been for two of the 50 detrital grains from the Marino Arkose. The grains in question were analysed in reconnaissance SHRIMP mode and gave poorly defined dates of ca.650 and 655 Ma respectively (Ireland et al. 1998 - DR tabulation shows 2 not 3 grains as stated in the paper). In reference to this data, Preiss (2000) cites the youngest single grain date to be $657 \pm 17 \mathrm{Ma}$. This later number has been used in the literature as an age determination for the type Adelaidean sequences in SA (for example: Halverson, 2006). 


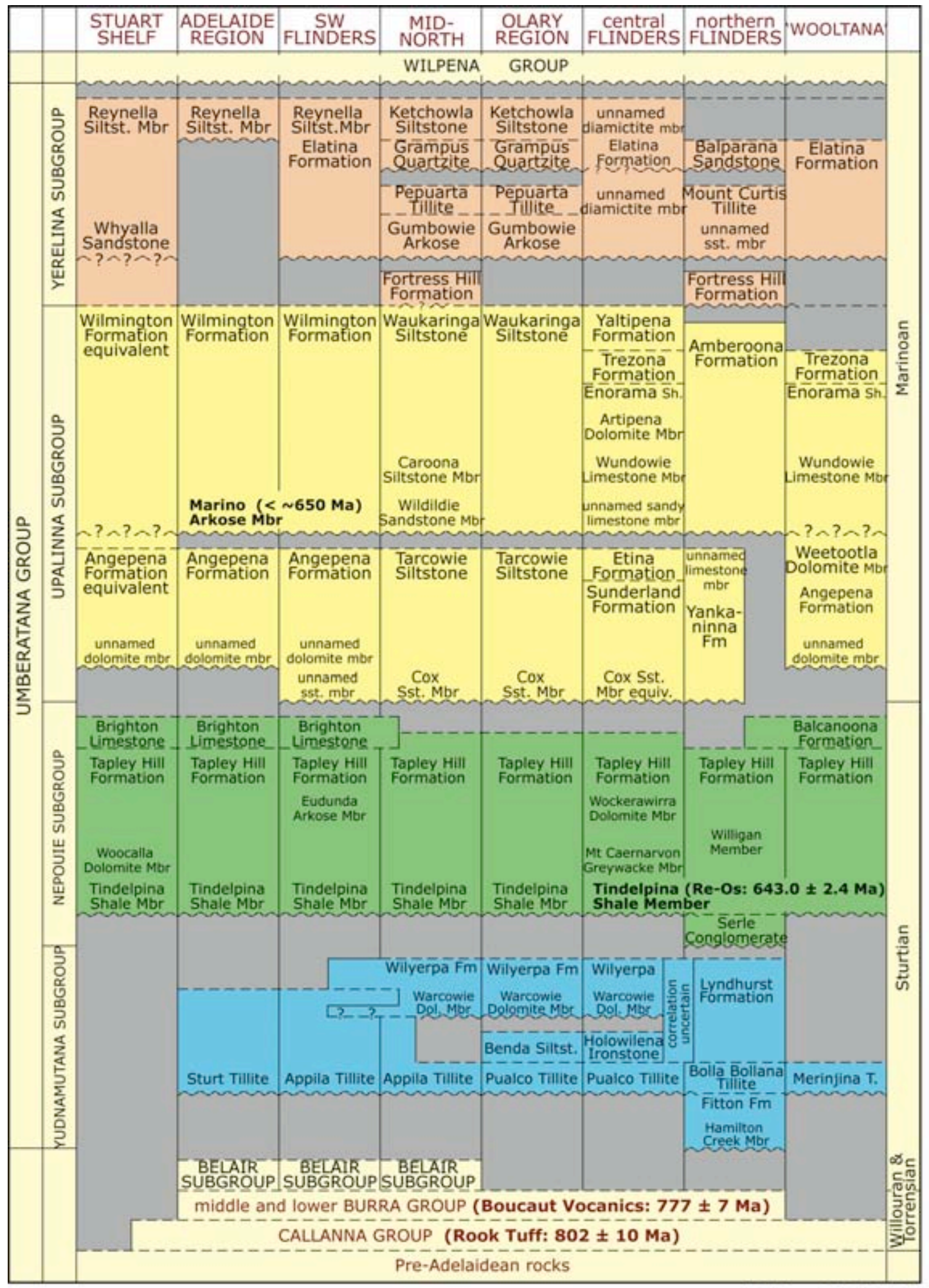

modified from PIRSA 98-0333

Fig. 12.3. Correlation of the Umberatana Group, modified from Preiss et al. (1998) showing the current age constraints on the lower Adelaidean and Sturtian sequences as discussed in the text.

In terms of significant recent geochronology, Kendall et al. (2006) report Re-Os dates for post Sturtian glacial black shales from the Tindelpina Shale Member of the Tapley Hill Formation at 645.1 $\pm 4.8 \mathrm{Ma}$ (Blinman) and $647 \pm 10$ (Stuart Creek on the Stuart Shelf). An overall age estimate for the Tindelpina Shale is $643.0 \pm 2.4 \mathrm{Ma}$ (see Fig. 9.3). These data were considered controversial until Fanning and Link presented the first U-Pb zircon date for a Sturtian interglacial volcaniclastic of 659 $\pm 6 \mathrm{Ma}$ (abstracts presented at GSA Philadelphia 2006 and AESC Perth 2008). 
In general terms, Sturtian sections across South Australia contain a series of diamictite layers that have interbedded silts (see for example Link and Gostin, 1981) and these have highly prospective layers that we consider to be tuffaceous or volcaniclastic in origin. West of Copley in northern South Australia, a tuffaceous bed in the lower Wilyerpa Formation, Yudnamutana Subgroup, Umberatana Group has a dominant igneous age component at ca. $659 \mathrm{Ma}$. This tuffaceous horizon is within the Wilyerpa Formation that comprises heterogeneous bedded diamictite, sandstone and siltstone containing ice-rafted debris, across the central and northern Flinders Ranges. At Copley, dropstones are abundant in the Wilyerpa Formation above and below the tuff bed. This $659 \mathrm{Ma}$ age constraint on the Sturtian glaciation is consistent with Re-Os ages on post-Sturtian glacial black shales from Tindelpina Member of Tapley Hill Formation South Australia (643 \pm 2.4 Ma; Kendall et al. 2006) and Aralka Formation, Central Australia (657.2 $\pm 5.4 \mathrm{Ma})$.

It is a reasonable conclusion that the Sturtian glaciation is diachronous on a global scale, and that there were likely several phases within Sturtian glaciation, precluding the possibility of a single Sturtian Snowball event.

\section{References}

Bowring, S.A., Grotzinger, J.P., Condon, D.J., Ramezani, J., Newall, M.J. \& Allen, P.A., 2007. Geochonologic constraints on the chronostratigraphic framework of the Neoproterozoic Huqf Supergroup, Sultanate of Oman. American Journal of Science, v. 307, p. 1097-1145.

Condon, D., Zhu, M., Bowring, S., Wang, W., Yang, A., and Jin, Y., 2005, U-Pb ages from the Neoproterozoic Doushantuo Formation, China: Science, v. 308, p. 95-98.

Fanning, C.M., and Link, P.K., 2004, U-Pb SHRIMP ages of Neoproterozoic (Sturtian) glaciogenic Pocatello Formation, southeastern Idaho: Geology, v. 10, p. 881-884.

Fanning, C.M., and Link, P.K., 2006, Constraints on the timing of the Sturtian glaciogene event from southern Australia; i.e. for the true Sturtian, Geological Society of America Abstracts with Programs, v. 38, no.7, p. 115.

Fanning, C.M., Ludwig, K.R., Forbes, B.G. and Preiss, W.V., 1986. Single and multiple grain U-Pb zircon analyses for the early Adelaidean Rook Tuff, Willouran Ranges, South Australia. Geological Society of Australia Abstracts v. 15, p. 71-72.

Halverson, G.P., 2006. A Neoproterozoic chronology. In: Xiao, S. \& Kaufman, A.J. (eds.) Neoproterozoic Geobiology and Paleobiology. Springer, Dordrecht, pp. 231-271.

Halverson, G.P., Hoffman, P.F., Schrag, D.P., Maloof, A.C., and Rice, A.H.N., 2005, Toward a Neoproterozoic composite carbon-isotope record: Geological Society of America Bulletin, v. 117, p. 1181-1207.

Hoffmann, K.-H., Condon, D.J., Bowring, S.A., and Crowley, J.L., 2004, U-Pb zircon date from the Neoproterozoic Ghaub Formation, Namibia: Constraints on Marinoan glaciation: Geology, v. 32, p. 817-820.

Howchin, W., 1901. Preliminary note on the existence of glacial beds of Cambrian age in South Australia. Transactions of the Royal Society of South Australia, v. 21, p. 74-86.

Ireland, T.R., Flötmann, T., Fanning, C.M., Gibson, G.M. and Preiss, W.V., 1998. Development of the early Paleozoic Pacific margin of Gondwana from detrital-zircon ages across the Delamerian orogen. Geology, v. 26, p. $243-246$.

Kendall, B., Creaser, R.A., and Selby, D., 2006. Re-Os geochronology of post-glacial black shales in Australia: Constraints on the timing of "Sturtian" glaciation. Geology, v. 34; p. 729-732.

Key, R., Liyungu, A., Njamu, F., Somwe, V., Banda, J., Mosley, P., Armstrong, R., 2001. The western arm of the Lufilian Arc in NW Zambia and its potential for copper mineralization, Journal of African Earth Sciences, v. 33, p. 501-528.

Link, P.K. and Gostin, V.A., 1981, Facies and paleogeography of Sturtian glacial strata (Late Precambrian), South Australia: American Journal of Science, v. 281, p. 353-374.

Lorentz, N.J., Corsetti, F.A., and Link, P.K., 2004. Seafloor precipitates and C-isotope stratigraphy from the Neoproterozoic Scout Mountain Member of the Pocatello Formation, southeast Idaho: Implications for Neoproterozoic Earth system behavior: Precambrian Research, v. 130, p. 57-70. 
Lund, K., Aleinikoff, J.N., Evans, K.V., and Fanning, C.M., 2003, SHRIMP U-Pb geochronology of Neoproterozoic Windermere Supergroup, central Idaho: Implications for rifting of western Laurentia and synchroneity of Sturtian glacial deposits: Geological Society of America Bulletin, v. 115, p. 349-372.

Preiss, W.V., 1987. The Adelaide Geosyncline: Late Proterozoic stratigraphy, sedimentation, palaeontology and tectonics. Geological Survey of South Australia Bulletin 53, 438 p.

Preiss, W.V., 2000. The Adelaide Geosyncline of South Australia and its significance in Neoproterozoic continental reconstruction. Precambrian Research v. 100, p. 21-63.

Preiss, W.V., Dyson, I.A., Reid, P.W., and Cowley, W.M., 1998, Revision of lithostratigraphic classification of the Umberatana Group: Mines and Energy South Australia Journal, v. 9, p. 36-42.

Smith, L.H., Kaufman, A.J., Knoll, A.H., and Link, P.K., 1994. Chemostratigraphy of predominantly siliciclastic Neoproterozoic successions: A case study of the Pocatello Formation and lower Brigham Group, Idaho, USA: Geological Magazine, v. 131, p. 301-314.

Wingate, M.T.D., Campbell, I.H., Compston, W. and Gibson, G.M., 1998. Ion microprobe U-Pb ages for Neoproterozoicbasaltic magmatism in south-central Australia and implications for the breakup of Rodinia. Precambrian Research, v. 87 , p. $135-159$.

Zhou, C., Tucker, R., Xiao, S., Peng, Z., Yuan, X., \& Chen, Z., 2004. New constraints on the ages of Neoproterozoic glaciations in south China. Geology, v. 32, p. 437-440. 


\section{The Selwyn Medal}

The Selwyn Medal is named in honour of Sir Alfred Selwyn, an eminent Victorian pioneering geologist and founder of the Geological Survey of Victoria. It is awarded, usually yearly, to recognise significant ongoing or former contributions of high calibre to any field of Victorian geology. A candidate for this medal should have made a major contribution to new knowledge of the geology of Victoria, or a significant reinterpretation of it based on critical observations, or has contributed importantly to a major mineral or oil discovery, or have produced important geological publications or have been involved successfully in the development of the geological profession.

\subsection{Nomination of Associate Professor Malcolm Wallace for the 2008 Selwyn Medal by Dr Sandra McLaren}

To: Ingrid Campbell

Chair - Awards Committee

Geological Society of Australia (Victoria Division)

Dear Ingrid,

I write to nominate Associate Professor Malcolm Wallace, of the School of Earth Sciences at the University of Melbourne, for the Selwyn Medal for 2008.

Please find following a summary of the breadth and significance of Assoc. Prof. Wallace's research. Malcolm's research is primarily in the field of sedimentary geology, but he has also published on a wide variety of other topics including carbonate hosted ore deposits, giant meteorite impact events, active tectonics and petroleum geology, including a number of papers in the high-profile, high-impact journals Nature and Geology.

In terms of his nomination for the Selwyn Medal, this summary focuses particularly on Malcolm's contribution to the advancement of understanding of the geology of southern Australia. In particular, I would like to highlight his achievements in three specific areas:

\section{1) Young tectonic evolution of southeast Australia}

The general perception of the Australian continent is that it is a geologically stable region where relatively little tectonism has occurred over the past $\sim 25$ million years. However, Malcolm's work indicates that southeastern Australia has been subject to a period of quite intense tectonic activity during the Neogene. In fact, his research provides clear evidence that this tectonic activity began about 10 million years ago and continues to the present day. Tectonic activity through the Neogene has many important economic implications. It is responsible for most of the structures in the offshore Gippsland Basin that host Australia's largest oil fields. In the Latrobe Valley, thick sequences of brown coal have been made economic for power generation through the uplift and erosion of cover sequences during the same period. Wallace's research emphasises the fundamental aspect of the tectonic activity, in terms of how the tectonic stress field works, through to its application to Economic Geology (see below). This research is helping to show that Australia is significantly more active than has been understood in the past, impacting on such questions as why we get earthquakes in Australia. It has, thus, had considerable impact outside academia. Malcolm's Australian Journal of Earth Sciences contribution on this topic [Wallace, M. W., J. A. Dickinson, D. H. Moore, \& M. Sandiford, 2005, Late Neogene Strandlines of southern Victoria: a unique record of eustacy and tectonics in Southeast Australia: Australian Journal Of Earth Sciences, v. 52, p. 277-295] was recognised by the award of the Stillwell Medal by the Geological Society of Australia as the best paper published in the journal in 2005. 


\section{2) Economic geology}

In addition to his basic research, Malcolm's research contributions in economic geology have had significant benefit for the minerals and petroleum industries. His applied research has focussed on two topics: lead-zinc deposits in carbonate rocks and seismic exploration as it relates to the petroleum industry. His economic geology paper in 2002 [Wallace, M. W., H. A. Middleton, B. Johns, \& S. Marshallsea, 2002, Hydrocarbons and Mississippi Valley-type sulfides in the Devonian reef complexes of the eastern Lennard Shelf, Canning Basin, Western Australia, in M. Keep, and S. J. Moss, eds., The Sedimentary Basins of Western Australia 3: Proceedings of the Petroleum Exploration Society of Australia Symposium: Perth, WA, p. 795-815] was judged to be the best paper of the Western Australian Basins Symposium. His seismic research has involved characterizing the sonic velocity behaviour of carbonate rocks overlying reservoirs, particularly in the Gippsland Basin, Victoria. Dramatic velocity changes in the carbonates have caused considerable problems in oil exploration in this region, with many unproductive wells being drilled (each one costing several tens of millions of dollars). In a 2002 paper [Wallace, M. W., G. R. Holdgate, J. Daniels, S. J. Gallagher, $\&$ A. Smith, 2002, Sonic velocity, submarine canyons, and burial diagenesis in Oligocene-Holocene cool-water carbonates, Gippsland Basin southeast Australia: American Association of Petroleum Geologists Bulletin, v. 86, p. 1593-1607] he explained for the first time the geological reasons for these variable sonic velocities and several petroleum exploration companies are now using this information to predict the position of petroleum reservoirs in the subsurface. This has resulted in significantly improved targeting of petroleum reservoirs in the Gippsland Basin and the work also has applications for other petroleum basins worldwide.

\section{3) Environmental and climate evolution of the southern Australian margin}

Malcolm's research on the stratigraphic and sedimentological research has contributed fundamentally to the understanding of the evolution of the shelf regions of southeast Australia during the Cenozoic. For example, his work with Gallagher and Holdgate has lead to better understanding of the buried shorelines and the previously undocumented submarine canyons offshore Victoria. In addition, his work with Holdgate has significantly improved the stratigraphy of the brown coals in Victoria, a resource critical to Victoria's energy needs. His research with Gallagher on the greenhouse/icehouse climate and environmental evolution of Victoria for last 80 million years forms an important analogue for future climate change in Victoria.

In addition to his many scientific contributions to Victorian Geology, Malcolm is also a committed and talented teacher. He has been heavily involved in undergraduate and postgraduate teaching at Melbourne University since 1991, training Victoria's next generation of geologists for the mineral, environmental and petroleum industries. Field teaching is one of his many strengths and, with characteristic passion and commitment, he has guided countless students in their development of this essential skill. His successful research career is also centred on research training. In a relatively short time (since 1991) he has supervised $13 \mathrm{PhD}$ students to completion as well as 65 Honours students, many of whom have worked on problems of Victorian Geology. He has a further 5 current PhD students, working on a wide variety of research problems. His former students (undergraduate and postgraduate) now have positions all over the world in academia and industry. Recently Malcolm was awarded the Melbourne University's Dean of Science award for his excellence in teaching.

Malcolm has also been a keen and regular participant in GSA activities. He was chairman of the Australasian Sedimentologists Group of the Geological Society of Australia from 1996 to 1998. He was committee member for the Geological Society of Australia Victorian Division from 1991 to 1993. 
In summary, Associate Professor Malcolm Wallace has fundamentally affected research and teaching of geology in Victoria and I believe he would be a very worthy candidate for the Selwyn Award in 2008 .

Dr. Sandra McLaren

School of Earth Sciences

The University of Melbourne

Victoria 3010

12 February 2008

\subsection{Nomination of Associate Professor Malcolm Wallace for the 2008 Selwyn Medal by Dr Phil Playford AM.}

Ingrid Campbell

Chair Awards Committee

Geological Society of Australia (Victoria Division)

Dear Ingrid

I wish to nominate Associate Professor Malcolm Wallace of the School of Earth Sciences at the University of Melbourne for the Selwyn Medal for 2008.

I have known Malcolm Wallace since 1985, when I was appointed as a co-supervisor of his $\mathrm{PhD}$ project on the Devonian reef complexes of the Canning Basin. He completed an outstanding PhD thesis - one of the very best of those that I have supervised or examined. Since then he has continued his academic career with great success.

Malcolm Wallace has made important contributions to geological knowledge, especially in Victoria but also in other parts of Australia and overseas. He has excelled in fields as diverse as carbonate sedimentology, lead-zinc mineralization, meteorite impact structures, Neogene tectonics, submarine canyons, and seismic velocities in petroleum exploration. His discovery of conclusive evidence for late Tertiary and Quaternary tectonism in Victoria was a milestone in understanding the Neogene structural development of southern Australia. This has been important to the petroleum, coal, and mineral-sands industries in Victoria and neighbouring States. His work on seismic velocities in carbonate rocks has been of major significance to petroleum exploration, especially in Bass Strait, but also in other parts of the world. It has led to the better targeting of wells drilled to test reservoirs below carbonate cover sequences, thereby improving their success rates and saving millions of exploration dollars.

Malcolm Wallace's research in Victoria, Western Australia, South Australia and Ireland is well known in Australia and overseas, and has earned him a high international reputation. He has publications in several top journals, including Nature, Geology, and Economic Geology. Altogether he has published more than 50 papers and book chapters based on his original research.

Malcolm Wallace is also known as an excellent lecturer, who maintains close rapport with his students, and has received a high award within the University for his lecturing ability. Because of his excellent reputation among students he has attracted many high-quality post-graduate candidates. I understand that he has now supervised more than $13 \mathrm{PhD}$ and 65 honours students, a remarkable record. Malcolm has always emphasised the need for his students to gain good skills in the field. 
Indeed, he is to be applauded as one of the few staff in Australian universities who still place strong emphasis on field geology, which is surely the most basic aspect of the science.

Malcolm has a quiet but confident personality and is highly respected and well liked by his colleagues and students, as well as by geoscientists outside academia. He is also known for his very high ethical standards. Very few geologists in Australia can claim such a strong record as a teacher, mentor, and research worker.

I have no doubt that Malcolm Wallace would be a very appropriate recipient of the Selwyn Medal for 2008.

Yours sincerely

Dr Phillip Playford AM

Geological Survey of Western Australia

100 Plain St

East Perth W.A. 6004

27 March 2008

\subsection{Selected Wallace Publications}

WALLACE, M. W., 1987, The role of internal erosion and sedimentation in the formation of stromatactis mudstones and associated lithologies: Journal of Sedimentary Petrology, v. 57, p. 695-700.

GOSTIN, V. A., R. R. KEAYS, AND M. W. WALLACE, 1989, Iridium Anomaly from the Acraman Impact Ejecta Horizon - Impacts Can Produce Sedimentary Iridium Peaks: Nature, v. 340, p. 542-544.

WALLACE, M. W., V. A. GOSTIN, AND R. R. KEAYS, 1989, Discovery of the Acraman impact ejecta blanket in the Officer Basin and its stratigraphic significance: Australian Journal of Earth Sciences, v. 36, p. 585-587.

WALLACE, M. W., 1990, Origin of dolomitization on the Barbwire Terrace, Canning Basin, Western Australia: Sedimentology, v. 37, p. 105-122.

WALLACE, M. W., V. A. GOSTIN, AND R. R. KEAYS, 1990, Acraman impact ejecta and host shales - Evidence for low-temperature mobilization of iridium and other platinoids: Geology, v. 18, p. 132-135.

WALLACE, M. W., V. A. GOSTIN, AND R. R. KEAYS, 1990, Spherules and shard-like clasts from the late Proterozoic Acraman impact ejecta horizon, South Australia: Meteoritics, v. 25, p. 161-165.

WALLACE, M. W., G. E. WILLIAMS, V. A. GOSTIN, AND R. R. KEAYS, 1990, The late Proterozoic Acraman impact; towards an understanding of impact events in the sedimentary record: Mines and Energy Review South Australia, v. 157 , p. 29-35.

WALLACE, M. W., R. R. KEAYS, AND V. A. GOSTIN, 1991, Stromatolitic iron oxides: evidence that sea-level changes can cause sedimentary iridium anomalies: Geology, v. 19, p. 551-554.

WALlACE, M. W., C. KERANS, P. E. PLAYFORD, AND A. MCMANUS, 1991, Burial diagenesis in the Upper Devonian reef complexes of the Geikie Gorge region, Canning Basin, Western Australia: American Association of Petroleum Geologists Bulletin, v. 75, p. 1018-1038.

WALLACE, M. W., BOTH, R.A., RUANO, S.M., HACH-ALI, P.F., \& LEES, T., 1994, Zebra textures from carbonatehosted sulfide deposits: sheet cavity networks produced by fracture and solution enlargement: Economic Geology, v. 89, p. 1183 - 1191.

WALLACE, M. W., V. A. GOSTIN, AND R. R. KEAYS, 1996, Sedimentology of the Neoproterozoic Acraman impactejecta horizon, South Australia, in Glikson, and Andrew, eds., Thematic issue; Australian impact structures: AGSO Journal of Australian Geology and Geophysics, v. 16: p. 443-451.

NICOLAIDES, S., AND M. W. WALLACE, 1997, Pressure dissolution and cementation in an Oligo-Miocene Nontropical Limestone (Clifton Formation), Otway Basin, Victoria, in N. P. James, and J. A. Clarke, eds., SEPM Special Publication No 56 - Cool water carbonates, p. 249-261. 
PEACE, W. M., AND M. W. WALLACE, 2000, Timing of mineralization at the Navan Zn-Pb deposit: A post-Arundian age for Irish mineralization: Geology, v. 28, p. 711-714.

PLAYFORD, P. E., AND M. W. WALLACE, 2001, Exhalative mineralization in Devonian reef complexes of the Canning Basin, Western Australia: Economic Geology, v. 96, p. 1595-1610.

REED, C., AND M. W. WALLACE, 2001, Diagenetic evidence for an epigenetic origin of the Courtbrown $\mathrm{Zn}-\mathrm{Pb}$ deposit, Ireland: Mineralium Deposita, v. 36, p. 428-441.

DICKINSON, J. A., M. W. WALLACE, G. R. HOLDGATE, S. J. GALLAGHER, AND L. THOMAS, 2002, Origin and timing of the Miocene-Pliocene unconformity in Southeast Australia: Journal of Sedimentary Research, v. 72, p. 288-303.

WALlACE, M. W., H. A. MIDDLETON, B. JOHNS, AND S. MARSHALLSEA, 2002, Hydrocarbons and Mississippi Valley-type sulfides in the Devonian reef complexes of the eastern Lennard Shelf, Canning Basin, Western Australia, in M. Keep, and S. J. Moss, eds., The Sedimentary Basins of Western Australia 3: Proceedings of the Petroleum Exploration Society of Australia Symposium: Perth, WA, p. 795-815.

(Best Paper at WABS 3 2002).

WALlACE, M. W., G. R. HOLDGATE, J. DANIELS, S. J. GALLAGHER, AND A. SMITH, 2002, Sonic velocity, submarine canyons, and burial diagenesis in Oligocene-Holocene cool-water carbonates, Gippsland Basin southeast Australia: American Association of Petroleum Geologists Bulletin, v. 86, p. 1593-1607.

WAllace, M. W., E. CONDILIS, A. POWELl, J. REDFEARN, K. AULD, M. WILTSHIRE, G. R. HOLDGATE, AND S. J. GALLAGHER, 2003, Geological controls on sonic velocity in the Cenozoic carbonates of the Northern Carnarvon Basin, North West Shelf, Western Australia: The Australian Petroleum Production and Exploration Association Journal, v. 43, p. 385-397.

WILLIAMS, G. E., AND M. W. WALLACE, 2003, The Acraman asteroid impact, South Australia: magnitude and implications for the Late Vendian environment: Journal of the Geological Society of London, v. 160, p. 545-554.

REED, C. P., AND M. W. WALLACE, 2004, Zn-Pb mineralisation in the Silvermines District, Ireland: A product of burial diagenesis: Mineralium Deposita, v. 39, p. 87 - 102.

WALlACE, M. W., J. A. DICKINSON, D. H. MOORE, AND M. SANDIFORD, 2005, Late Neogene Strandlines of southern Victoria: a unique record of eustasy and tectonics in Southeast Australia: Australian Journal Of Earth Sciences, v. 52, p. 277-295.

(2005 Stillwell Award for best paper in Australian Journal of Earth Sciences)

MITCHELL, J.K., WALLACE, M.W. and HOLDGATE, G.R. 2007. Pliocene - Pleistocene history of the Gippsland Basin outer shelf and canyon heads, southeast Australia. Australian Journal of Earth Sciences v. 54, 49 - 64. 
NOTES: 


\section{The 2008 GSAV SELWYN MEMORIAL LECTURE:}

\section{Historical geology, the Pleistocene glacial controversy, and the rise of modern Earth science}

\section{Professor Paul F. Hoffman,}

Dept of Earth \& Planetary Sciences, Harvard University, Cambridge, MA 02138, USA

and

Geology \& Geophysics, School of Earth

\& Environmental Sciences, The University of Adelaide, SA 5005, Australia

hoffman@eps.harvard.edu

\author{
Biography:
}

A Canadian field geologist, Paul Hoffman spent 25 years mapping two-billionyear-old sedimentary basins and orogenic belts in the northwest of the Canadian Shield for the Geological Survey of Canada. An early advocate of Precambrian plate tectonics, he bridged the gap between "soft-rock" and "hard-rock" geology. A practitioner of the interdependence of research science and geological mapping, he left the Geological Survey in 1992 after it de-emphasised research. Joining the new School of Earth and Ocean Science at the University of Victoria in western Canada, he began a 15-year project studying late Precambrian paleoceanography and paleoclimate in newly-independent Namibia. This work flourished after he moved to Harvard University in 1994 and led to his outspoken support for the "snowball earth" hypothesis of global glaciation. His students have carried out extensive field projects in Arctic Alaska, Mongolia, Morocco and the Svalbard archipelago. He is a Fellow of the Royal Society of Canada and the American Association for the Advancement of Science, a foreign member of the U.S. National Academy of Sciences and an honorary member of the American Academy of Arts and Sciences. Among his awards are the William Logan Medal of the Geological Association of Canada, the Alfred Wegener Medal of the European Union of Geosciences and the Henno Martin Medal of the Geological Society of Namibia.

From the time of Galileo (1564-1642) and Newton (1642-1727) until the end of the $18^{\text {th }}$ Century, scientists sought to understand the Universe through the discovery and elucidation of "fixed" (timeless) laws, established at the time of Creation. After 1800, following the recognition that fossils mostly represent extinct species, Georges Cuvier (1769-1832) and Alexandre Brongniart (1770-1847) set about reconstructing the succession of "former worlds" based on systematic stratigraphic geology. With this came the realization that the present Earth can only be understood in the context of its own history. By 1830, historical geology had paved the way for other sciences concerned with systems that change over time, or even evolve, like biology, psychology, astronomy and cosmology (Toulmin \& Goodfield, 1965). The rise of historical science as an essential complement to process-directed science marks a turning point in the development of science as a whole, and is geology's most profound contribution to human thought.

When geologists in northern Europe and North America began to reconstruct the former worlds, they immediately encountered problems of interpretation in the youngest strata before the Recent, the Pleistocene or "Newer Pliocene" as they were then called. Stiff clays "confusedly mixed with boulders", called "till" by Scots farmers, contained marine fauna of modern Arctic aspect (Smith, 1836). Many of the boulders had come great distances because their lithologies were alien to the bedrock of their resting places. The till was commonly draped upon terrestrial deposits and both were elevated above sea level. The Arctic fauna implied a colder climate and its marine origin required a transient submergence of the land beneath the sea. Many tills took the form of dam-like ridges (moraines) oriented transverse to the valleys they occupied, and where they rested upon hard substrates the latter were characteristically streamlined, fluted and grooved by some unknown agency of enormous power. Formerly, tills and subjacent landforms were attributed to the Biblical Flood or to a tsunami (the destructive 1755 Lisbon tsunami was still fresh in mind), but the Arctic marine fauna was taken as evidence for invasions of icebergs and sea ice by most influential British and American 
geologists in the first half of the $19^{\text {th }}$ Century, notably Roderick Murchison (1792-1871), Edward Hitchcock (1793-1864) and Charles Lyell (1797-1875).

An alternative interpretation, one which attributed the strange Pleistocene features to mountain glaciers, inflated to ice-sheets of continental dimensions (then only peripherally known in the actual world), had been advocated to no avail by the Norwegian Jens Esmark (1863-1839) in 1824, the Swiss Ignace Venetz (1788-1859) in 1830 and the German A. Bernhardi (1797-1849) in 1832. The glacial theory created uproar only after it was taken up enthusiastically in 1837-1844 by an ambitious, young, multilingual, Swiss ichthyologist and paleo-ichthyologist named Louis Agassiz (1807-1873). Agassiz $(1837,1840 \mathrm{a})$ believed that geological periods represented intervals of evolutionary stasis, punctuated by mass extinctions and re-creations. For him, the Pleistocene glaciation was responsible for the extinction of the boreal megafauna prior to the creation of mankind, a conjecture that was easily disproved - the boreal megafauna survived the Ice Age and their demise coincided with human arrivals. Nevertheless, Agassiz $(1840 \mathrm{~b}, 1842)$ created great excitement by demonstrating that most of the British Isles had been buried by a Pleistocene ice sheet. The excitement was short-lived: the glacial theory was soon rejected by most British geologists and emerged triumphant only after the Scottish glacial revival led by Thomas Jamieson and the Geikie brothers beginning in 1862 (Fig. 14.1). The principal reason for Agassiz's failure was that he offered no explanation for glacial submergence - there being no marine faunas in the Swiss Pleistocene deposits. In fact, Agassiz's theory predicted that sea level should have fallen during the glacial period by about $215 \mathrm{~m}$, because of the transfer of water into continental ice sheets (MacLaren, 1842).

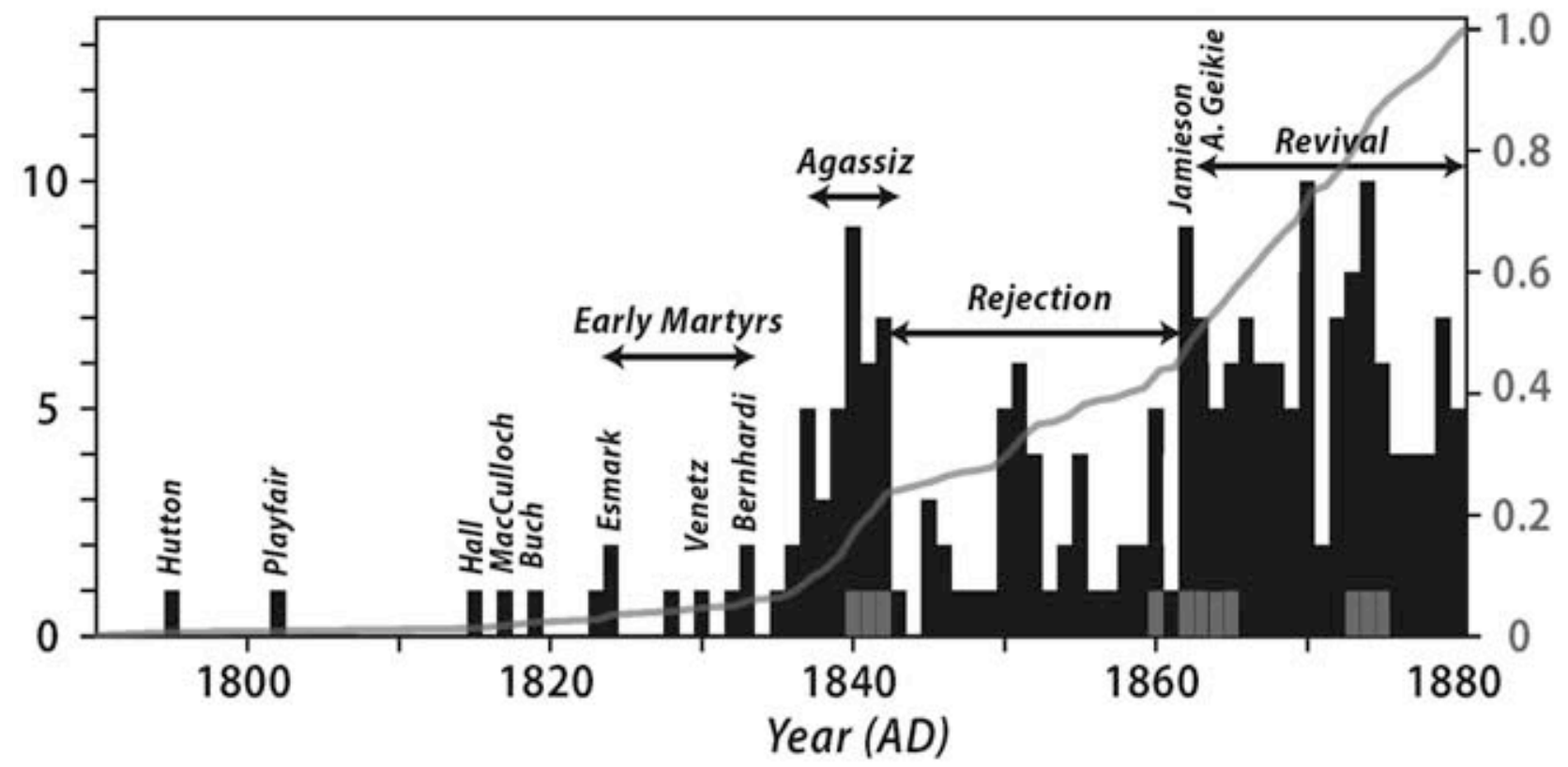

Fig. 14.1. Histogram of papers (black) and books (grey) on Pleistocene (Newer Pliocene) “drift” deposits, 1790-1880.

The excitement over Agassiz's glacial theory coincided exactly with the discovery of the Antarctic continent by Dumont d'Urville, Charles Wilkes and James Clark Ross in 1840-41. Joseph Adhémar (1797-1862), a Parisian mathematics tutor, put the two together and postulated that the northern hemisphere glaciation in the Pleistocene was matched by a southern hemisphere glaciation today. He attributed the alternation to the precession of the Earth orbit about every 22 thousand years, reasoning that glaciation occurred in the hemisphere with the longer winter according to Kepler's Law governing elliptical orbits. Revolutions of the Sea (Adhémar, 1842) seems an odd title for an orbital theory of ice ages; it alludes to his attempt to resolve the submergence problem. He envisioned that the interior of the Antarctic ice sheet was so thick that it displaced the center of mass of the Earth, causing sea level to rise in the glaciated hemisphere and fall in its opposite, consistent with soundings in the polar seas. Adhémar's climate theory was flawed, precession has no effect on mean annual insolation, but the 
Scottish physicists James Croll (1821-1890) and William (Lord Kelvin) Thomson (1824-1907) took up Adhémar's explanation of submergence in opposition to a new proposal put forward by the Scottish geologist Thomas Jamieson (1829-1913). Jamieson (1865) had suggested that the land had subsided under the tremendous weight of glacial ice and was slowly rebounding after the ice had melted away. Jamieson's (1882) carefully marshalled evidence eventually won the day and his glacio-isostatic concept for the vertical motions of the crust underlies the principal means by which geophysicists still study the Earth's internal viscosity.

If geologists were untroubled by the idea of a Pleistocene ice age per se, climate physicists were surprised. They assumed that the climate had never been much colder than the present. The Sun was slowly cooling, or so they thought, and therefore the Earth's surface temperature should also be in decline. Paleobotanical evidence (palm fronds in France) indicated that the Cretaceous and early Tertiary were warmer than today, and historical evidence showed that Medieval times were milder than the Little Ice Age, from which Europe had not yet emerged. If the Pleistocene was much colder than the Holocene, something was missing in physicists understanding of the climate system. The French mathematician Joseph Fourier (1768-1830) first suggested that the atmosphere might preferentially absorb some of the long-wavelength radiation the Earth emits while being transparent to visible light from the Sun, but he discounted its affect on climate (Fourier, 1824). It was the Irish-born physicist John Tyndall (1820-1893) who experimentally demonstrated the "greenhouse" effect, expressly to account "for all the perturbations of climate that the researches of geology have revealed" (Tyndall, 1861). Tyndall (1863) recognized that, although water vapor is "more essential to the vegetable life of England than clothing is to man", it is the atmosphere's variable minor constituents, notably carbon dioxide, that must be responsible for bidirectional climate change of geological magnitude.

Criteria used in the recognition of Pleistocene glacial action were soon applied to older strata. In 1859, tillites of Late Paleozoic age were discovered at $21^{\circ} \mathrm{N}$ latitude in the Talchir Coal Basin of eastern India. In 1870 , similar deposits were found at $30^{\circ} \mathrm{S}$ latitude in Natal, South Africa. In both areas, the ancient ice sheets had flowed away from the present equator. Australia and South America followed and in nearly all cases the ice flowed from the adjacent ocean onto the land. These observations aroused a young German meteorologist, Alfred Wegener (1880-1930), to write: "The Permian ice age poses an unsolvable riddle for all models that do not dare to assume horizontal displacements of the continents" (Wegener, 1912). Closing the Atlantic and Indian oceans, however, "takes everything mysterious away from the problem".

The glacial theory for Pleistocene ice ages sparked one of the most heated geological controversies of the $19^{\text {th }}$ Century. Its lasting impact was in spawning the concepts of glacial isostasy (Thomas Jamieson), the greenhouse effect (John Tyndall) and continental drift (Alfred Wegener). None of these ideas came easily. When the glacial theory was finally accepted in 1862, Jens Esmark (had he lived) would have been 99 years old. When continental drift was verified in 1967, Wegener would have been 87. When the greenhouse effect finally found favour in 1958, Tyndall would have been 138. Thomas Jamieson, the most creative and original of the Scottish glacial revivalists, remains virtually unknown to this day.

\section{References}

Adhémar, J.A., 1842. Révolutions de la Mer (Revolutions of the Sea). Fain et Thunot, Paris, $101 \mathrm{p}$.

Agassiz, L. (1840a) Études sur les glaciers (Studies on Glaciers). English facsimile translation by Albert Carozzi (1967) preceded by the Discourse of Neuschâtel (Agassiz, 1837). Hafner, New York, 213 p.

Agassiz, L. (1840b) Glaciers, and the evidence of their having once existed in Scotland, Ireland, and England (paper read at the Geological Society, London, Nov. 4, 1840). The Athenaeum 682, 927-928. Reprinted (1841) Philosophical Magazine ( $2^{\text {nd }}$ series) 18, 569-574.

Agassiz, L. (1842) The glacial theory and its recent progress. Edinburgh New Philosophical Journal 33, 217-283. 
Bernhardi, A. (1832) Wie kamen die aus dem Norden stammenden Felsbruchstücke und Geshiebe, welche man in Norddeutschland und den benachbarten Ländern findet, an ihre gegenwärtigen Fundorte? (How did the rock fragments and boulders of northern origin found in northern Germany and neighboring countries get to their present positions?) Jahrbuch für Mineralogie, Geognosie, Geologie, und Petrefaktenkunde 3, 257-267.

Esmark, J. (1824) Bidrag til vor jordklodes historie (Contribution to the geological history of our Earth). Magazin for Naturvidenskaberne 2(1), 29-54. English translation (1827) Edinburgh New Philosophical Journal 2, 107-121.

Fourier, J. (1824) Remarques générales sur les températures du globe terrestre et des espaces planétaires (General remarks on the temperature of the terrestrial globe and the planetary spaces). Annales de Chimie et de Physique ( $2^{\text {nd }}$ series) 27 , 136-167. English translation by E. Burgess (1837) American Journal of Science and Arts 32, 1-20.

Jamieson, T.F. (1865) On the history of the last geological changes in Scotland. Quaterly Journal of the Geological Society of London 21, 161-203.

Jamieson, T.F. (1882) On the cause of the depression and re-elevation of the land during the glacial period. Geological Magazine 9, 400-407, 457- 466.

MacLaren, C. (1842) The glacier theory of Prof. Agassiz. American Journal of Science and Arts 42, 346-365.

Smith, J. (1836) On indications of changes in the relative levels of Sea and Land in the West of Scotland. Proceedings of the Geological Society of London 2, 427-429.

Toulmin, S., Goodfield, J. (1965) The Discovery of Time. Harper \& Row, New York, 280 p.

Tyndall, J. (1861) On the absorbtion and radiation of heat by gases and vapours, and on the physical connexion of radiation, absorbtion, and conduction - the Bakerian Lecture. Philosophical Magazine (series 4) 22, 169-194, 273285.

Tyndall, J. (1863) On the radiation through the Earth's atmosphere. Philosophical Magazine (series 4) 25, $200-206$.

Wegener, A. (1912) Die Entstehung der Kontinente (The origin of the continents). Petermanns Geographische Mitteilungen 58(I), 185-195, 253-256. English translation by W.R. Jacoby (2001) Journal of Geodynamics 32, 29-63.

Venetz, I. (1830) Sur l'extension qu'il présume que les glaciers avaient autrefois, et sur leur retraits dans leurs limites actuelles (On the inferred extension of glaciers in ancient times and their retreat to their present limits). Actes Société Helvetique des Sciences Naturelles, Lausanne, 31. 